\title{
Basin analysis and aqueous chemistry of fluids in the Oriskany Sandstone, Appalachian Basin, USA
}

Jamie C. Skeen

West Virginia University

Follow this and additional works at: https://researchrepository.wvu.edu/etd

\section{Recommended Citation}

Skeen, Jamie C., "Basin analysis and aqueous chemistry of fluids in the Oriskany Sandstone, Appalachian Basin, USA" (2010). Graduate Theses, Dissertations, and Problem Reports. 2978.

https://researchrepository.wvu.edu/etd/2978

This Thesis is protected by copyright and/or related rights. It has been brought to you by the The Research Repository @ WVU with permission from the rights-holder(s). You are free to use this Thesis in any way that is permitted by the copyright and related rights legislation that applies to your use. For other uses you must obtain permission from the rights-holder(s) directly, unless additional rights are indicated by a Creative Commons license in the record and/ or on the work itself. This Thesis has been accepted for inclusion in WVU Graduate Theses, Dissertations, and Problem Reports collection by an authorized administrator of The Research Repository @ WVU. For more information, please contact researchrepository@mail.wvu.edu. 


\title{
Basin Analysis and Aqueous Chemistry of Fluids in the Oriskany Sandstone, Appalachian Basin, USA.
}

\author{
by \\ Jamie C. Skeen \\ fulfillment of the requirements for the degree of \\ Master of Science in Geology \\ Approved by \\ Timothy Carr, Ph.D., Committee Chairperson \\ Joseph Donovan, Ph.D. \\ Dorothy Vesper, Ph.D. \\ Department of Geology \& Geography \\ Morgantown, West Virginia \\ 2010
}

Thesis submitted to the Eberly College of Arts and Sciences at West Virginia University in partial

Keywords: $\mathrm{CO}_{2}$ sequestration; Appalachian basin; Oriskany Sandstone 


\begin{abstract}
Basin Analysis and Aqueous Chemistry of Fluids in the Oriskany Sandstone, Appalachian Basin, USA.

Jamie C Skeen

The Oriskany Sandstone of the Appalachian basin is a widely distributed saline aquifer which has produced large quantities of hydrocarbons. Currently the Oriskany is host to numerous gas storage fields and is a potential target for large-scale geologic storage of $\mathrm{CO}_{2}$. Published and unpublished data of rock characteristics, pressure, temperature, and formation water geochemistry, along with new brine samples were integrated within a geographical information system to better understand the regional-scale hydrogeological regime and its relation to geologic $\mathrm{CO}_{2}$ sequestration potential. The up-dip flow of the Oriskany Sandstone formation waters is generally controlled by outcrops at high elevation to the east and at low elevation to the west, and opposed by increased salinity-induced buoyancy forces down-dip. The flow pattern is substantiated by the salinity distributions, with relatively lower salinity at recharge to the east and west due to mixing with fresh meteoric water and higher salinity at depth. The Oriskany is generally underpressured, which would aid in sequestering $\mathrm{CO}_{2}$ by lowering injection and displacement pressures. The geothermal gradient for the Appalachain basin, approximately $20^{\circ} \mathrm{C} / \mathrm{km}$, is lower than what is expected for cratonic rocks. This could lower the potential for and relative speed of $\mathrm{CO}_{2}$ migration. Large variations in brine geochemistry, temperature, and pressure will have a major influence on potential for long-term entrapment of $\mathrm{CO}_{2}$ in the Oriskany Sandstone.
\end{abstract}




\section{ACKNOWLEDGEMENTS}

I would like to extend my sincere thanks to Dr. Tim Carr, my advisor for this project, for his expertise, support, and patience throughout this study.

I would like to thank Southeast Regional Carbon Sequestration Partnership (SECARB) and Marshall Miller and Associates, Inc. for funding this thesis. I would like to thank those who provided data and samples: Gregory Wrightstone of Texas Keystone, Jason Stewart of Dominion Exploration \& Production, Mark Gredell of Spectra Energy, Kerima Haddad and Kristi Jacobs formerly of Chesapeake Energy, Richard Silber, Joe Hileman, and Bob Gilmore of NiSource, Babatunde Ojo of DCNR_Bureau of Topographic and Geologic Survey, Jeff Jahn of US Silica Company, Ron Riley of the Ohio Division of Geological Survey and Eb Warner. I would also like to the West Virginia Stat GIS Technical Center for scanning maps and providing other data that was used in the making of geologic maps.

I would like to thank my parents, James and Helene Uphold for their support and encouragement. Thanks to all of my friends, especially Angela Lilly and Megan Ganak, for believing in me and being there when I needed a sympathetic ear. Most importantly of all I want to thank my husband, Joe, for his love, patience and support through this ordeal. 


\section{TABLE OF CONTENTS}

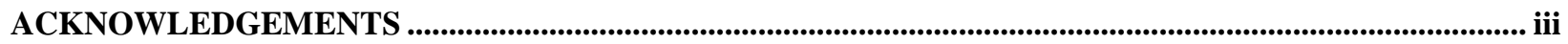

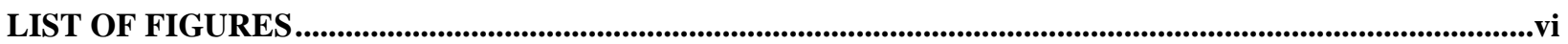

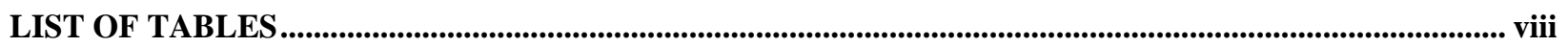

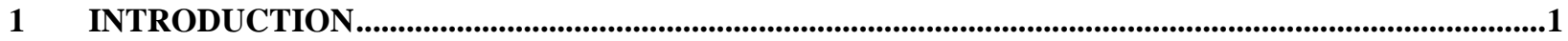

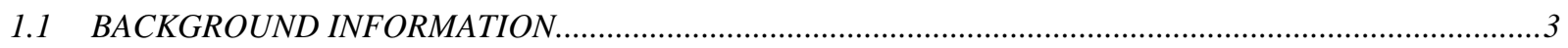

1.2 GEOLOGIC SETTING AND REGIONAL STRATIGRAPHY ……............................................................

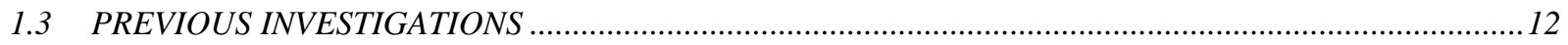

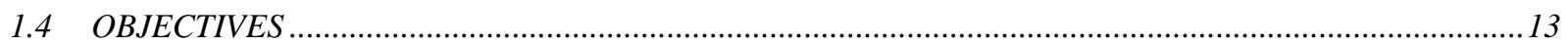

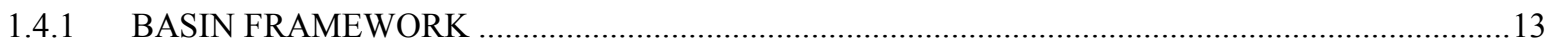

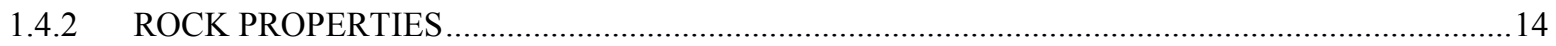

1.4.3 FLOW AND CHEMISTRY OF FORMATION WATER ...................................................................14

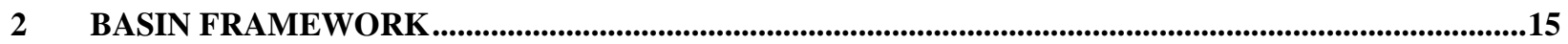

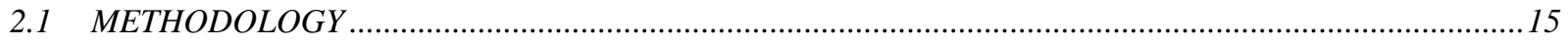

2.2 RESULTS

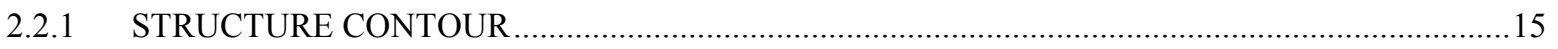

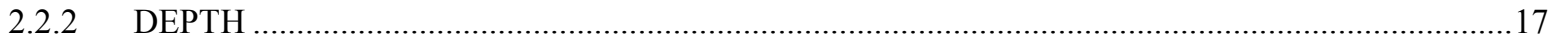

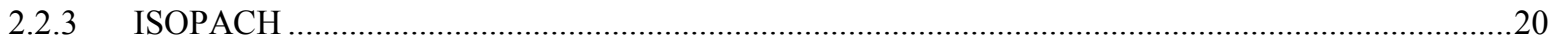

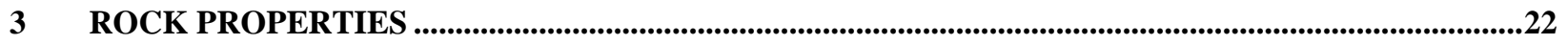

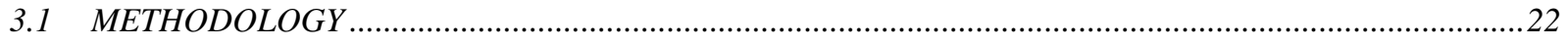

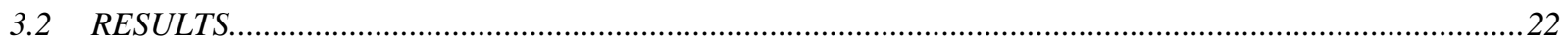

4 FLOW VARIABLES AND CHEMISTRY OF FORMATION WATER ...................................................25 


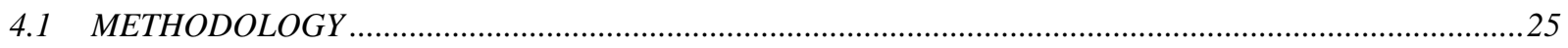

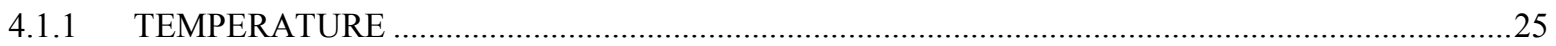

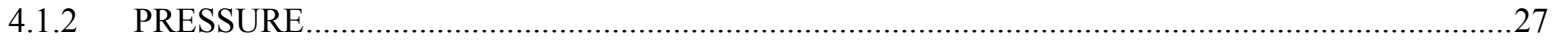

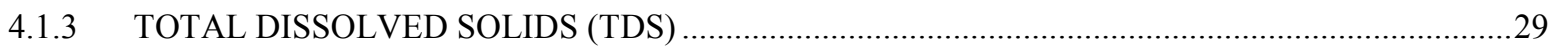

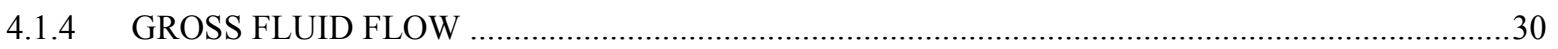

4.2 RESULTS

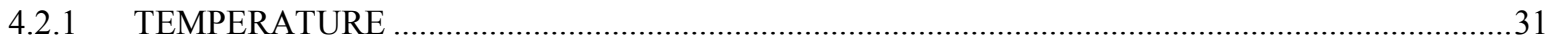

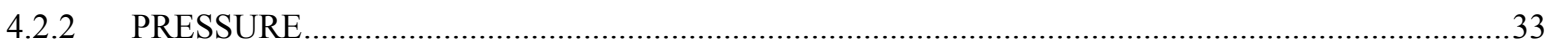

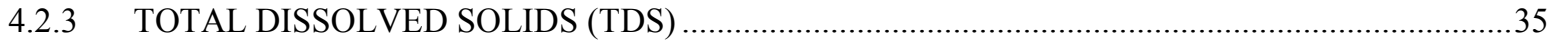

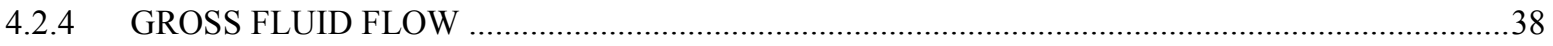

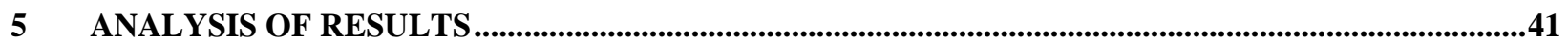

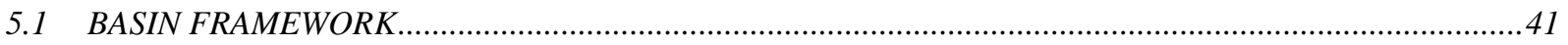

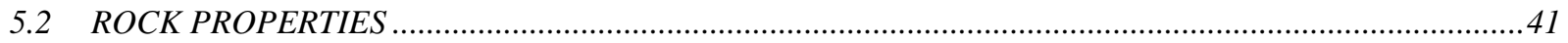

5.3 FLOW VARIABLES AND CHEMISTRY OF FORMATION WATER …………….....................................

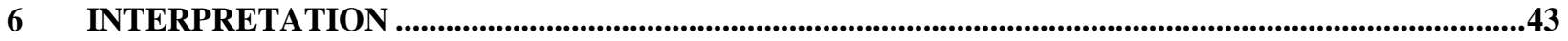

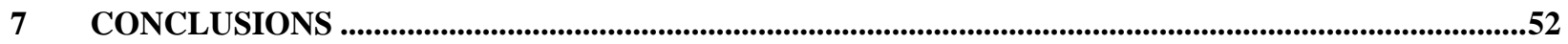

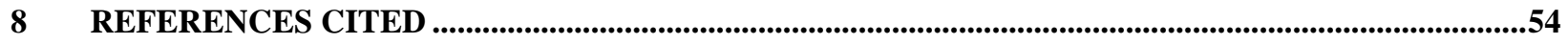

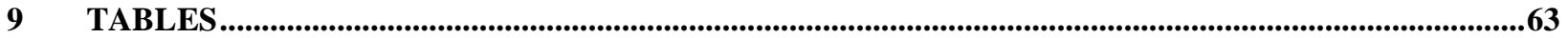

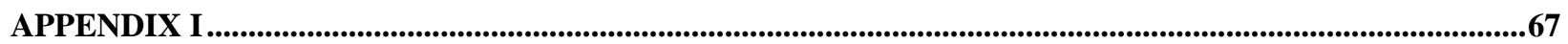

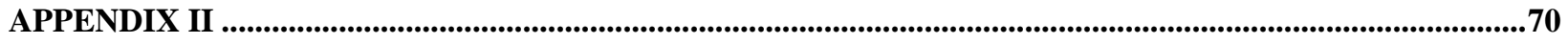

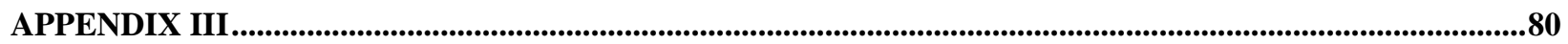

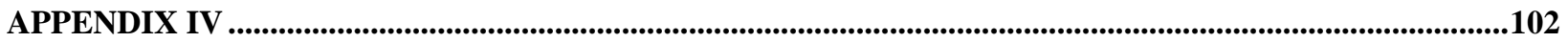




\section{LIST OF FIGURES}

Figure 1-1. Approximate time frame for physical and chemical trapping mechanisms .............. 5

Figure 1-2. At depths greater than 800 meters, injected $\mathrm{CO}_{2}$ is a supercritical fluid ................. 7

Figure 1-3. Study area within the Appalachian basin ........................................................ 9

Figure 1-4. Stratigraphic column of Lower Devonian................................................... 11

Figure 2-1. Structure on the top of the Oriskany Sandstone................................................ 16

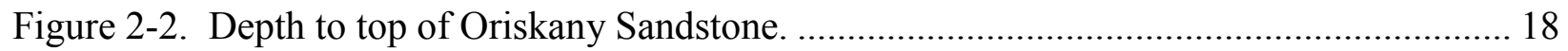

Figure 2-3. Oriskany Sandstone potential sequestration area ............................................... 19

Figure 2-3. Oriskany Sandstone thickness estimate ........................................................... 21

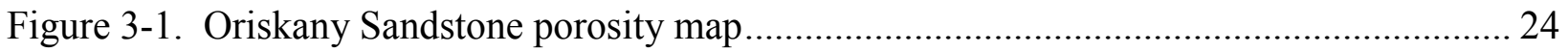

Figure 4-1. Oriskany Sandstone formation temperature $\left({ }^{\circ} \mathrm{C}\right)$ plotted against depth $(\mathrm{m})$........... 26

Figure 4-2. Oriskany Sandstone formation pressure $(\mathrm{kPa})$ plotted against depth $(\mathrm{m})$.............. 28

Figure 4-3. Oriskany Sandstone formation temperature $\left({ }^{\circ} \mathrm{C}\right)$ at top of structure..................... 32

Figure 4-4. Oriskany Sandstone formation pressure $(\mathrm{kPa})$ at top of structure .......................... 34

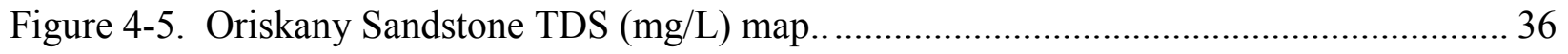

Figure 4-6. Oriskany Sandstone $\mathrm{Ca} / \mathrm{Mg}$ concentration ratio map........................................ 37

Figure 4-7. Oriskany Sandstone formation water density map.......................................... 39 
Figure 4-8. Oriskany Sandstone equivalent hydraulic head

Figure 6-1. Oriskany Sandstone estimated pore volume map 45

Figure 6-2. Oriskany Sandstone total storage capacity estimate low efficiency factor.............. 46

Figure 6-3. Oriskany Sandstone total storage capacity estimate high efficiency factor. 47

Figure 6-4. Oriskany Sandstone solubility storage capacity estimate low efficiency factor....... 50

Figure 6-5. Oriskany Sandstone solubility storage capacity estimate high efficiency factor..... 51 


\section{LIST OF TABLES}

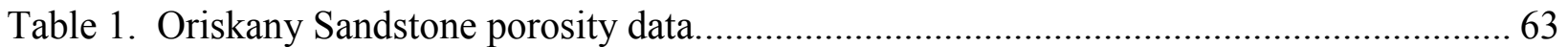

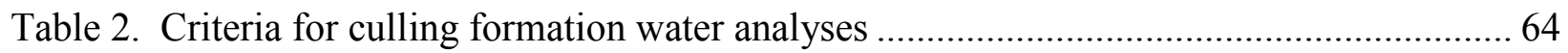

Table 3. Polynomial fit correlating formation temperature to density of $\mathrm{CO}_{2}$-saturated brine... 65

Table 4. Polynomial fit correlating temperature to formation $\mathrm{CO}_{2}$ concentration ................... 66 


\section{INTRODUCTION}

The increasing level of greenhouse gases (GHGs) in the atmosphere is a growing concern as a contributing factor to global climate change. Atmospheric levels of $\mathrm{CO}_{2}$ have risen significantly from preindustrial levels of 280 parts per million (ppm) to present levels of 384

ppm. Evidence suggests the observed rise in atmospheric $\mathrm{CO}_{2}$ levels is the result of expanded use of fossil fuels (Tans, 2008). The United States contributes approximately $20 \%$ of the world's GHG emissions, most of which is due to the combustion of fossil fuels (5.6 billion metric tons of $\mathrm{CO}_{2}$ per year; EIA, 2009). Of this amount, 3.8 billion metric tons is from stationary sources, such as power plants, ethanol plants, cement plants, etc. Predictions of increased global fossil energy use during this century imply a continued increase in carbon emissions, and rising $\mathrm{CO}_{2}$ levels in the atmosphere unless a major change is made in how carbon is managed (EIA, 2009).

Carbon capture and storage in deep geologic formations is one of several carbon management options being studied for reducing anthropogenic $\mathrm{CO}_{2}$ (Bachu, 2008; Dilmore et al., 2008). This type of carbon management, referred to as geologic storage, involves injecting $\mathrm{CO}_{2}$ into depleted or near-depleted oil and gas reservoirs, deep coal beds, or deep saline aquifers (USDOE, 1999; Birkholzer and Tsang, 2007; Dilmore et al., 2008). Geological storage technology could be immediately applicable due to the knowledge and experience gained in industries, such as oil and gas exploration and production, natural gas storage, and deep liquid waste and acid gas disposal (Bachu, 2008).

It has been established that the flow of formation waters in sedimentary basins plays an important role in the generation, migration, and accumulation of hydrocarbons (Bachu, 1995b; Anfort et al., 2001; Carr et al., 2005). Also, a better understanding of these regional-scale 
hydrogeological systems provides a basis to evaluate the potential for long-term containment of $\mathrm{CO}_{2}$ storage in geologic structures (Carr et al., 2005). Specific technical issues influencing deep $\mathrm{CO}_{2}$ storage include reservoir pore volume, injectivity, and containment mechanisms. Spatialvariability in brine chemistry, mineralogy, pressure, temperature, porosity, formation extent, and reservoir characteristics is poorly understood (Cook and Benson, 2005; Czernichowski-Lauriol et al., 2006; Bachu et al., 2007; Dilmore et al., 2008). Consequently, storage capacity and potential storage containment time need to be better established on both regional and site-specific scales.

The ideal saline aquifer for geologic storage of $\mathrm{CO}_{2}$ is comprised of porous rock saturated with brine at sufficient depth to maintain $\mathrm{CO}_{2}$ in a supercritical condition. It must be capped by one or more regionally extensive impermeable rock formations that enable trapping of injected $\mathrm{CO}_{2}$ over long periods of time. In addition, areas of converging fluid flow can aid in long-term lateral containment of injected $\mathrm{CO}_{2}$ (Bachu et al., 2007; Bachu, 2008). A saline aquifer assessed for storage is defined as a porous and permeable body of rock containing water with total dissolved solids (TDS) greater than 10,000 ppm, which can store large volumes of $\mathrm{CO}_{2}$. A saline aquifer can include more than one named regionally-extensive geologic formation or be defined as only part of a formation (Bachu et al., 2007).

The storage capacity for $\mathrm{CO}_{2}$ is a geological resource whose availability can be expressed using the resources and reserves concept just as other energy or mineral commodities such as oil and gas, copper, or gold are classified (CSLF, 2005; Bachu et al., 2007). A resource is a commodity whose quantities are estimated to exist at a given time and can be currently or potentially extracted, it can be either in-place or inferred. A reserve is a commodity whose quantities are known to exist and be economically recoverable with current technologies and economic conditions (Frailey et al., 2006; Bachu et al., 2007). This paper attempts to provide 
improved geospatial data to better evaluate the Oriskany Sandstone as a regional geologic storage resource and to influence future site screening. Site specific evaluations are beyond the scope of this effort and will require additional geologic, geophysical, cultural, and economic data.

More accurate estimates of porosity, salinity, and flow potential of formation water could allow a better estimation of $\mathrm{CO}_{2}$ storage capacity, as well as indicating possible migration directions, and information on hydrocarbon accumulation (Bachu, 1995b; Anfort et al., 2001; Carr et al., 2005). With the use of both new and existing data, this study has analyzed the Oriskany Sandstone throughout the study area within the Appalachian basin in terms of the parameters that influence storage resource volume, injectivity, and long-term containment. The often significant differences (i.e. depth, thickness, salinity, pressure, temperature, and porosity) that exist across the extent of the Oriskany Sandstone have been taken into account. This study has estimated the salinity, large scale potential flow of the formation water, and basin-scale storage resource volume of the Oriskany Sandstone.

\subsection{BACKGROUND INFORMATION}

The concept of separating $\mathrm{CO}_{2}$ from flue gases and storing it away from the atmosphere emerged in the late 1970 's, and research and development into $\mathrm{CO}_{2}$ storage began in the early 1990's (Cook and Benson, 2005). Carbon capture and storage has become a promising option for reducing $\mathrm{CO}_{2}$ emissions in the past decade (Benson, 2005). Three main forms of $\mathrm{CO}_{2}$ storage have been identified: surface mineral carbonation, in oceans, and in deep geological media (IPCC, 2005). Of these three options, only deep geological storage could be immediately applied due to knowledge and experience gained in the oil and gas and deep liquid disposal 
industries (Bachu, 2008). Deep geological storage has a large estimated capacity, although unevenly distributed worldwide, and has the potential retention time of centuries to millions of years (IPCC, 2005; Bachu et al., 2007).

Storage of $\mathrm{CO}_{2}$ within geological media is possible through a combination of physical and chemical trapping, know as hydrodynamic trapping, that operate over different time frames (IPCC, 2005; Bachu et al., 2007) (Figure 1-1). Physical trapping is when $\mathrm{CO}_{2}$ is immobilized as a free gas or supercritical fluid (Bachu, 2008). Two types of physical trapping exist: (1) static trapping in stratigraphic and structural traps, much like natural gas is trapped under a lowpermeability cap rock in gas reservoirs; and (2) residual-gas trapping as a residual, not-wetting phase in the pore spaces of the rock. Chemical trapping occurs when $\mathrm{CO}_{2}$ dissolves in subsurface fluid, which is referred to as solubility or ionic trapping. The dissolved $\mathrm{CO}_{2}$ can then react directly or indirectly with the rock matrix or formation waters and form carbonate minerals, this process is known as mineral trapping (Benson, 2005; Bachu et al., 2007). Static trapping is the most important mechanism during and immediately after $\mathrm{CO}_{2}$ injection (Benson, 2005). Residual-gas, solubility and mineral trapping mechanisms operate over a longer time scale, but play a vital role in increasing the safety and security of $\mathrm{CO}_{2}$ storage after injection has ceased (Bachu, 2008). The volume and efficiency of long-term trapping of $\mathrm{CO}_{2}$ within geologic media is strongly influenced by the temperature, pressure, and geochemistry of the fluid and rock matrix.

Sedimentary basins are the most probable location for geological $\mathrm{CO}_{2}$ storage. The deposits here are typically up to many thousands of meters thick and consist of alternating layers of sandstone and shale. Permeable and porous layers, typically sandstone or limestone, are candidates for storage reservoirs, with porosity needed for storage capacity and higher 


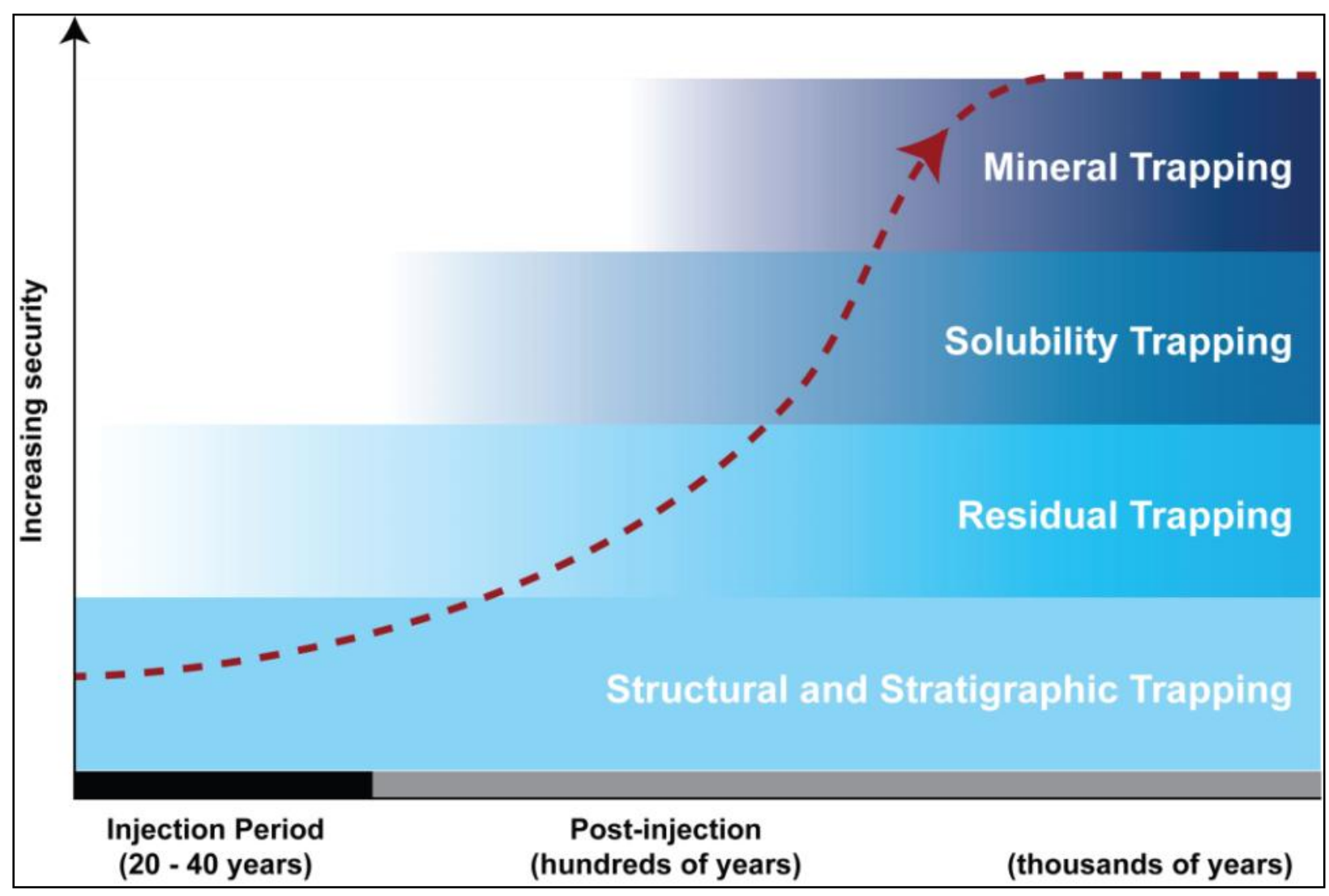

Figure 1-1. Approximate time frame for various physical and chemical trapping mechanisms involved in $\mathrm{CO}_{2}$ sequestration. Source:

http://www.co2crc.com.au/images/geopics/trappingsecurity.jpg 
permeability allowing $\mathrm{CO}_{2}$ injection. Overlying shale or evaporite layers of low permeability are potential seal zones to prevent $\mathrm{CO}_{2}$ escape to the surface (Benson, 2005; Bachu, 2008). Within sedimentary basins three categories of geological media are considered as potential storage sites for $\mathrm{CO}_{2}$ (Bachu et al., 2007): (1) oil and gas reservoirs; (2) deep coal seams; and (3) deep saline aquifers.

Deep saline aquifers, as defined by Bachu et al. (2007), contain water of total dissolved solids (TDS) greater than 10,000 $\mathrm{mg} / \mathrm{L}$ and are present in most sedimentary basins worldwide. The deep saline aquifers have the largest potential storage resource capacity of all geologic media considered as suitable storage sites, and are an immediately-available prospect for geological $\mathrm{CO}_{2}$ storage (Cook and Benson, 2005; Bachu et al., 2007; Bachu, 2008). However, less is typically known about deep saline aquifers because they lack sufficient subsurface data, causing uncertainty regarding its suitability for $\mathrm{CO}_{2}$ sequestration (USDOE, 2007). The storage capacity of such aquifers and the potential storage containment time need to be established on regional as well as site-specific scales.

Specific-technical issues influencing deep $\mathrm{CO}_{2}$ storage include trapping mechanisms, as well as spatial-variability in brine chemistry, mineralogy, pressure, temperature, porosity, permeability, formation extent, and reservoir characteristics (Cook and Benson, 2005; Czernichowski-Lauriol et al., 2006; Bachu et al., 2007; Dilmore et al., 2008). Potential saline aquifers must meet four basic criteria for $\mathrm{CO}_{2}$ sequestration. (1) The temperature and pressure conditions must be adequate to keep the injected $\mathrm{CO}_{2}$ in the dense supercritical or liquid phase (at the critical point for $\mathrm{CO}_{2}$ the temperature $\mathrm{T}_{\mathrm{c}}$ is $31.1^{\circ} \mathrm{C}$ and $\mathrm{P}_{\mathrm{c}}$ is 7.83 megapascals, or MPa an approximate depth of 800 meters; Figure 1-2). (2) The aquifer must have adequate permeability and porosity for injectivity. (3) An adequate seal must be present to provide vertical containment 


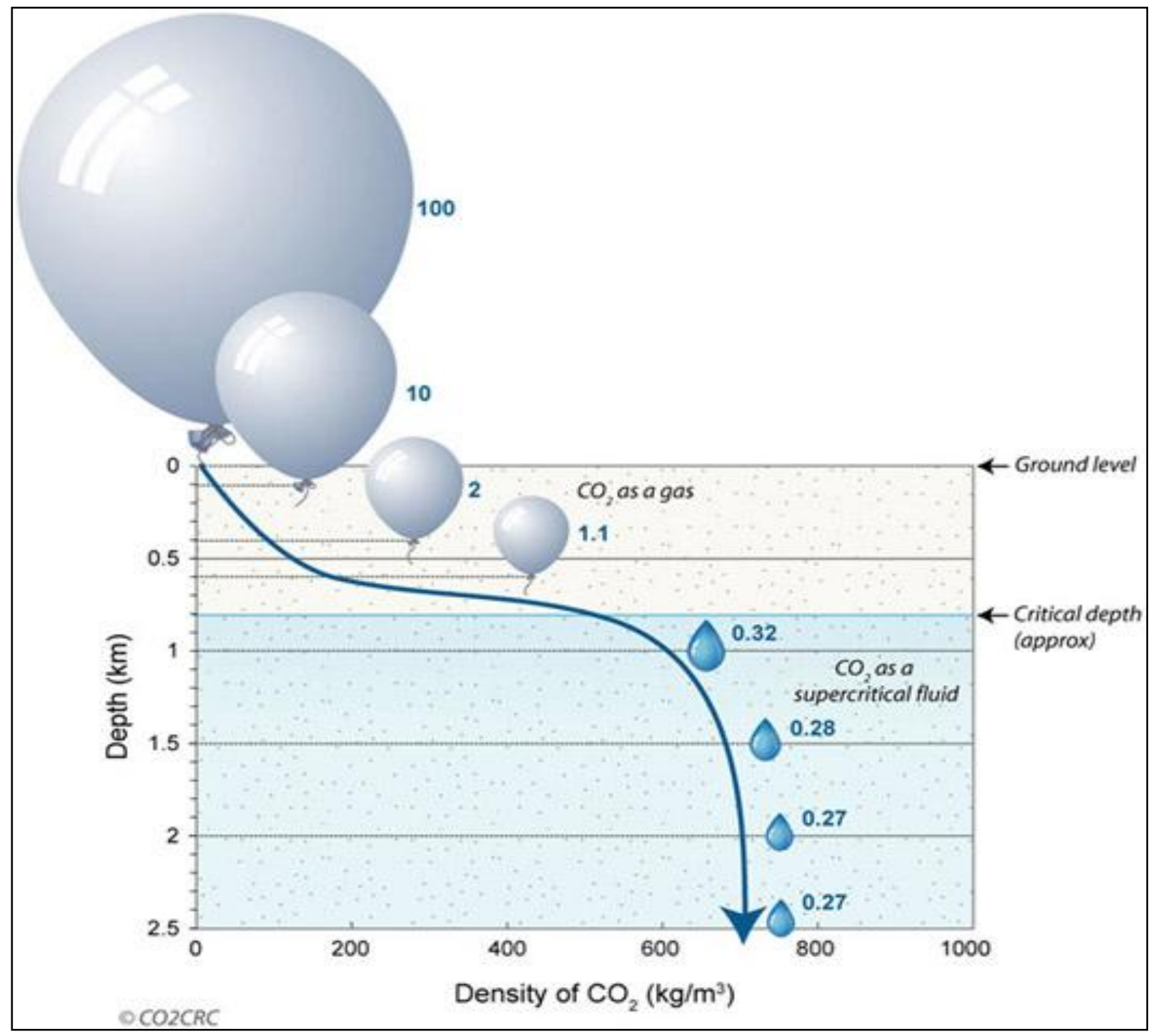

Figure 1-2. At depths greater than 800 meters, injected $\mathrm{CO}_{2}$ is a supercritical fluid. Source: http://www.wvcarb.org/cc-overview.php 
and limit flow of $\mathrm{CO}_{2}$ to the surface. (4) The TDS should be more than $10,000 \mathrm{mg} / \mathrm{L}$, the approximate upper limit of potable drinking water (Bachu et al., 2007; USDOE, 2007; Bachu, 2008).

\subsection{GEOLOGIC SETTING AND REGIONAL STRATIGRAPHY}

The Appalachian basin (Figure 1-3) is approximately 500 kilometers $(\mathrm{km})$ wide and $1,000 \mathrm{~km}$ long and encompasses a broad area between the Canadian Shield to the north, the Allegheny front to the east and the Cincinnati arch to the west (UTBEG, 2008). It represents part of an ancient foreland basin in the eastern United States that contains complex geology formed by a series of continental plate collisions. This deformation resulted in the formation of the Appalachian Mountains and large areas of stretched, faulted, and deformed ridges and valleys (USGS, 2008; UTBEG, 2008). The elongate, asymmetrical northeast-southwest trending central axis of the Appalachian basin is underlain by a succession of strata greater than 3,000 meters thick (UTBEG, 2008). Overlying a major interregional unconformity in the Appalachian basin is the Oriskany Sandstone, a widespread gas reservoir and saline aquifer (Deicchio, et al., 1984).

The Oriskany Sandstone of the Appalachian basin represents the Deerpark stage of the Early Devonian (Diecchio, 1985). The Oriskany Sandstone was named by Vanuxem (1839) for its type locality in Oriskany Falls, Oneida County, New York. At this location, the Oriskany is a white, fossiliferous quartz arenite (Opritza, 1996; Patchen and Harper, 1996). Most of the studies done on the formation before 1930 were for purposes of clarifying the stratigraphic and paleontological relationships of Lower Devonian and Upper Silurian rocks (for example, see 


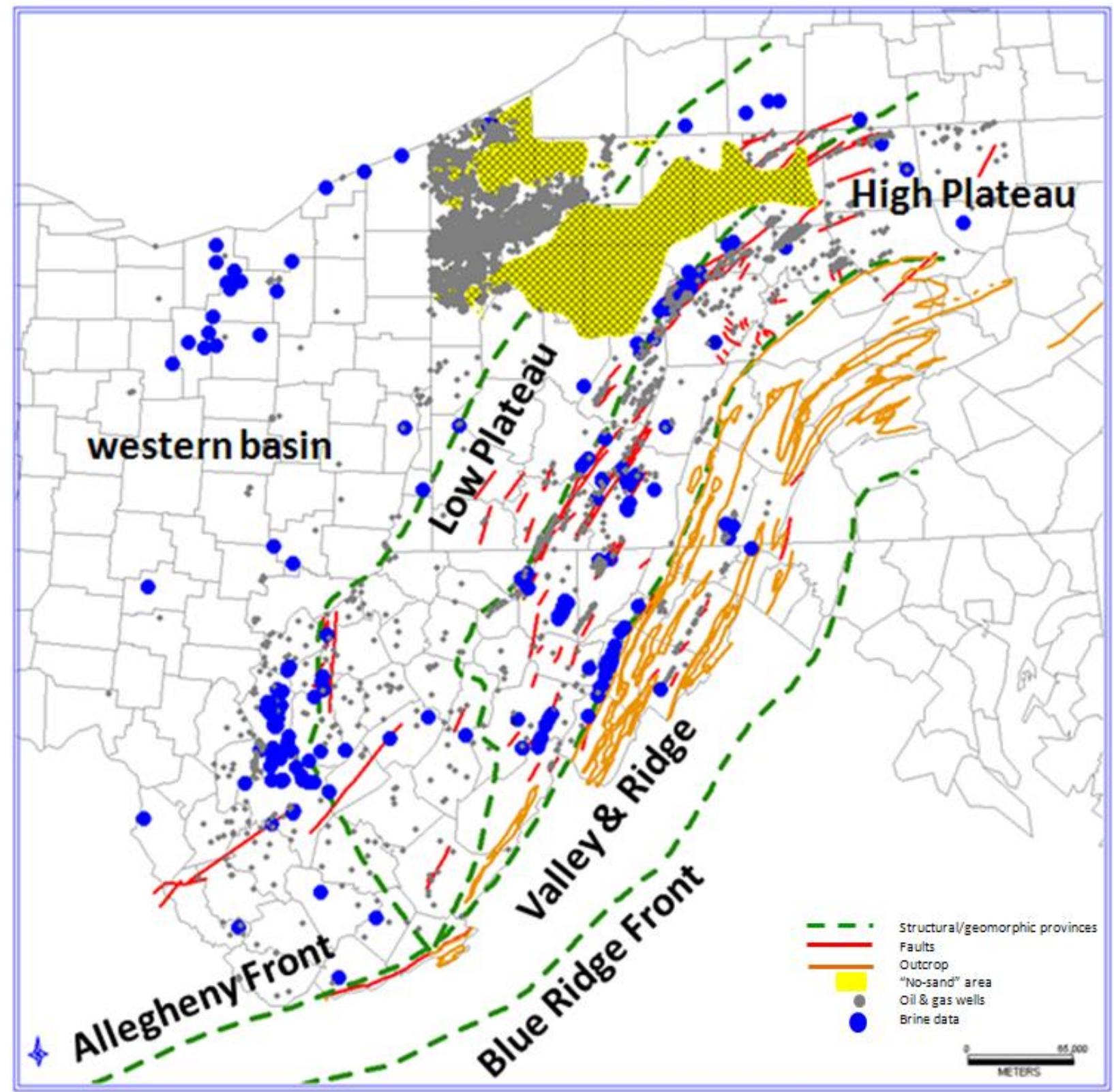

Figure 1-3. Study area within the Appalachian basin that includes the states of Maryland, New York, Ohio, Pennsylvania, and West Virginia. Green dashed lines indicate the Appalachian basin structural/geomorphic provinces of Diecchio (1985). Red lines indicate faults within the Oriskany Sandstone (MRCSP, 2008). Orange lines depict area of known Oriskany outcrop (MRCSP, 2008). Yellow hatched polygons indicate areas of "no-sand" (Diecchio, 1985). Small gray circles are oil and gas wells with data. Large blue circles indicate wells with brine data. 
Swartz, 1913). However, since 1930, the Oriskany has become one of the most important formations for gas exploration and gas storage in the Appalachian basin. As a result, the Oriskany has been the subject of numerous studies related to structure, stratigraphy, petrology, petrophysics, and other topics (Diecchio et al., 1984; Deicchio, 1985).

The Oriskany is typically a fossiliferous quartzarenite cemented with locally-variable amounts of quartz or calcite. It can be traced continuously through New York, Pennsylvania, Ohio, Maryland, West Virginia, Virginia, and Kentucky (Diecchio, 1985; Bruner and Smosna, 2008). The Oriskany typically unconformably overlies strata of the Helderberg Limestone or equivalents, and is overlain by Onondaga Limestone, Huntersville Chert, or Needmore Shale (Figure 1-4), which vary from limestone to chert to shale and are locally sandy (Diecchio, 1985). Since the Oriskany is a major deep gas producer within the basin, data such as pressure, temperature, porosity, permeability, and brine composition are available (Diecchio et al., 1984). The data indicate that there exists intergranular and fracture porosity within the Oriskany, and overlying thick low-permeability zones within the Appalachian basin provide the potential for vertical containment (Diecchio, et al., 1984; Gupta et al., 2005).

The Oriskany commonly has been considered to be overpressured because of initial open flow pressures in some areas of the basin as high as 31,026 kiloPascal (kPa) (Wickstrom et al., 2005). However, pressure/depth ratios range from 5.13 to $16.70 \mathrm{kPa} / \mathrm{m}$, averaging $9.92 \mathrm{kPa} / \mathrm{m}$, which is close to the normal hydrostatic pressure gradient for freshwater. Russell (1972) suggested that, on average, the Oriskany is not an overpressured reservoir, and that overpressuring is more common in areas of intense deformation. Patchen and Harper (1996), however, indicate that the more highly deformed areas, such as south-central Pennsylvania, western Maryland, and eastern West Virginia, tend to have abnormally underpressured 


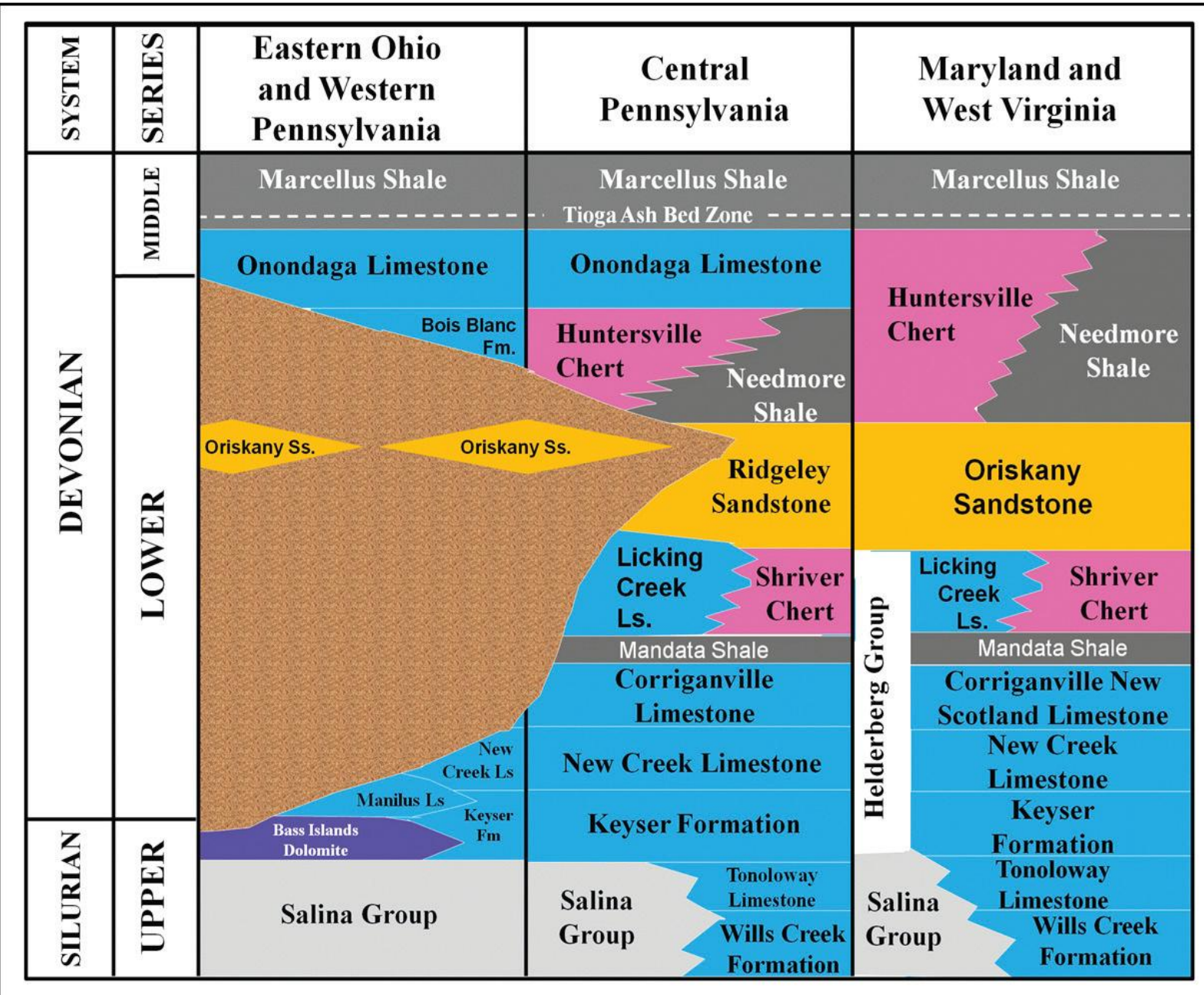

Figure 1-4. Stratigraphic column of Lower Devonian of Maryland, Ohio, Pennsylvania, and

West Virginia. Based on stratigraphic column of Pennsylvania Geological and Economic Survey. 
reservoirs. Pressure-depth rations in this area range from 5.78 to 11.25 with an average of 8.84 . In contrast, pressure-depth ratios in the "less deformed" areas of western Pennsylvania and south-central New York range from 5.13 to 16.70 , averaging 10.33. The relationship of degree of deformation to pressure gradient is not readily apparent but might be due, at least in part, to the ability of the reservoir to maintain fluids following intense fracturing. Brines in the Oriskany Sandstone have been reported to have very variable salinity values, often ranging into the 200,000 to $350,000 \mathrm{ppm}$ range, and a wealth of varied chemistries (Kelley et al., 1973). The highest values are for chloride, followed by sodium and calcium. Smaller but significant concentrations of magnesium and bromide also commonly occur.

\subsection{PREVIOUS INVESTIGATIONS}

The Oriskany Sandstone has been analyzed recently by the USDOE to determine its $\mathrm{CO}_{2}$ sequestration reservoir potential (Soong et al., 2004a, 2004b; Dilmore et al., 2008). These studies of the solubility and displacement volumes for $\mathrm{CO}_{2}$ sequestration potential were based upon brine samples taken from a single well in Indiana County, Pennsylvania and samples from a single well were assumed to be representative of Oriskany Formation brine chemistry basin wide (Dilmore et al., 2008). Due to varying depth, thickness, porosity, temperature, pressure, and brine composition, additional analyses over a more extensive area are needed in order to properly characterize the Oriskany saline aquifer. Each of these variables independently has the potential to affect the volume and long-term retention of $\mathrm{CO}_{2}$ that could be injected and/or stored.

At standard atmospheric conditions $\mathrm{CO}_{2}$ is a stable gas that is slightly denser than air. For temperatures greater than $31.1{ }^{\circ} \mathrm{C}$ and pressures greater than $7.38 \mathrm{MPa}, \mathrm{CO}_{2}$ is a supercritical 
fluid. In its supercritical state, $\mathrm{CO}_{2}$ has the high-density characteristics of a liquid yet behaves like a gas by filling all the available volume (Bachu and Stewart, 2002; Bachu 2008). In order for the injected $\mathrm{CO}_{2}$ to remain in a supercritical phase, the Oriskany Sandstone must be 800 meters or greater in depth. Maintaining this supercritical phase is important because the injected $\mathrm{CO}_{2}$ occupies several orders of magnitude less volume than in its gaseous phase. These deep depths will also reduce the relative buoyancy of the $\mathrm{CO}_{2}$ and help to insure an adequate thickness of confining layers is present above the Oriskany to act as an impermeable seal.

Estimating the porosity and thickness of the Oriskany will provide a means to calculate the reservoir's potential volume that can be used to store $\mathrm{CO}_{2}$ when the depth criterion is taken into consideration. The average porosity value controls the maximum possible space that the sequestered $\mathrm{CO}_{2}$ can occupy. The brine composition of the aqueous fluids within this porosity is critical for determining the volume of $\mathrm{CO}_{2}$ trapped through dissolution into the formation water and precipitated as mineral components. The solubility of $\mathrm{CO}_{2}$ in the formation water decreases with increasing water salinity (Brennan and Burruss, 2006).

\subsection{OBJECTIVES}

\subsubsection{BASIN FRAMEWORK}

The geology, stratigraphy, and geometry of the Oriskany were described to assist in approximating the flow regime and volume estimation. Well data was processed using a subsurface geologic information system $\left(\mathrm{Petra}^{\mathrm{TM}}\right)$, to generate structure contour maps, isopach maps, and grids for calculating $\mathrm{CO}_{2}$ storage volume. 


\subsubsection{ROCK PROPERTIES}

The porosity of basin rocks is a hydraulic property that has control on the subsurface fluid flow (Bachu and Undershultz, 1992). Core- and well-scale porosity were used to estimate the basin (regional) scale porosity of the Oriskany. The well-scale porosity is the vertical arithmetic average of the core-scale values weighted by the thickness of the uniter sampled. The basin (regional) scale estimates were obtained from the large-scale spatially averaged well-scale porosity.

\subsubsection{FLOW AND CHEMISTRY OF FORMATION WATER}

Knowledge of sedimentary basin geology, lithology, and hydrostratigraphy is important in understanding the flow of formation waters (Bachu and Undershultz, 1995; Bachu, 1997). Fluid flow is driven by fluid pressure gradients, which may be influenced to greater or lesser degrees by compaction, topographic variations in water column height, pressure loss to flow, and spatial variations in temperature, pressure, elevation, density, and fluid composition (Bachu, 1995a). Spatial variations in temperature, pressure, density, and TDS concentrations were mapped across the basin. All data used in this study is available on the West Virginia GIS Technical Center website http://wvgis.wvu.edu. 


\section{BASIN FRAMEWORK}

\subsection{METHODOLOGY}

The geology, stratigraphy, and geometry of the Appalachian basin have been described to assist in approximating the potential flow regime. Latitude, longitude, elevation, and depth to formation data was obtained from drilling records available from the Maryland, Ohio, Pennsylvania, and West Virginia Geological Surveys, as well as participating oil and gas companies. The elevation and depth values were expressed relative to sea level. The data was processed and the resulting grids and maps were checked for internal consistency. The processed data was used to generate a structure contour map, a depth map and an isopach map using the minimum curvature gridding parameters. Using a minimum depth of 800 meters the potential sequestration area within which $\mathrm{CO}_{2}$ would be supercritical in the Oriskany was determined. The produced grids were used to estimate the basin volume needed to calculate potential $\mathrm{CO}_{2}$ storage volume.

\subsection{RESULTS}

\subsubsection{STRUCTURE CONTOUR}

The Oriskany Sandstone forms dips toward the center of the Appalachian basin along a northeast-southwest trend (Figure 2-1). At the center of the study area, it reaches a maximum depth $\leq 2,000$ meters mean sea level (MSL). It shallows towards outcrop areas to the east (along the Allegheny Front and Eastern Overthrust Belt) and west (Cincinnati Arch). The area within the known outcrop belt could not be accurately represented with the limited data and therefore was not contoured. 


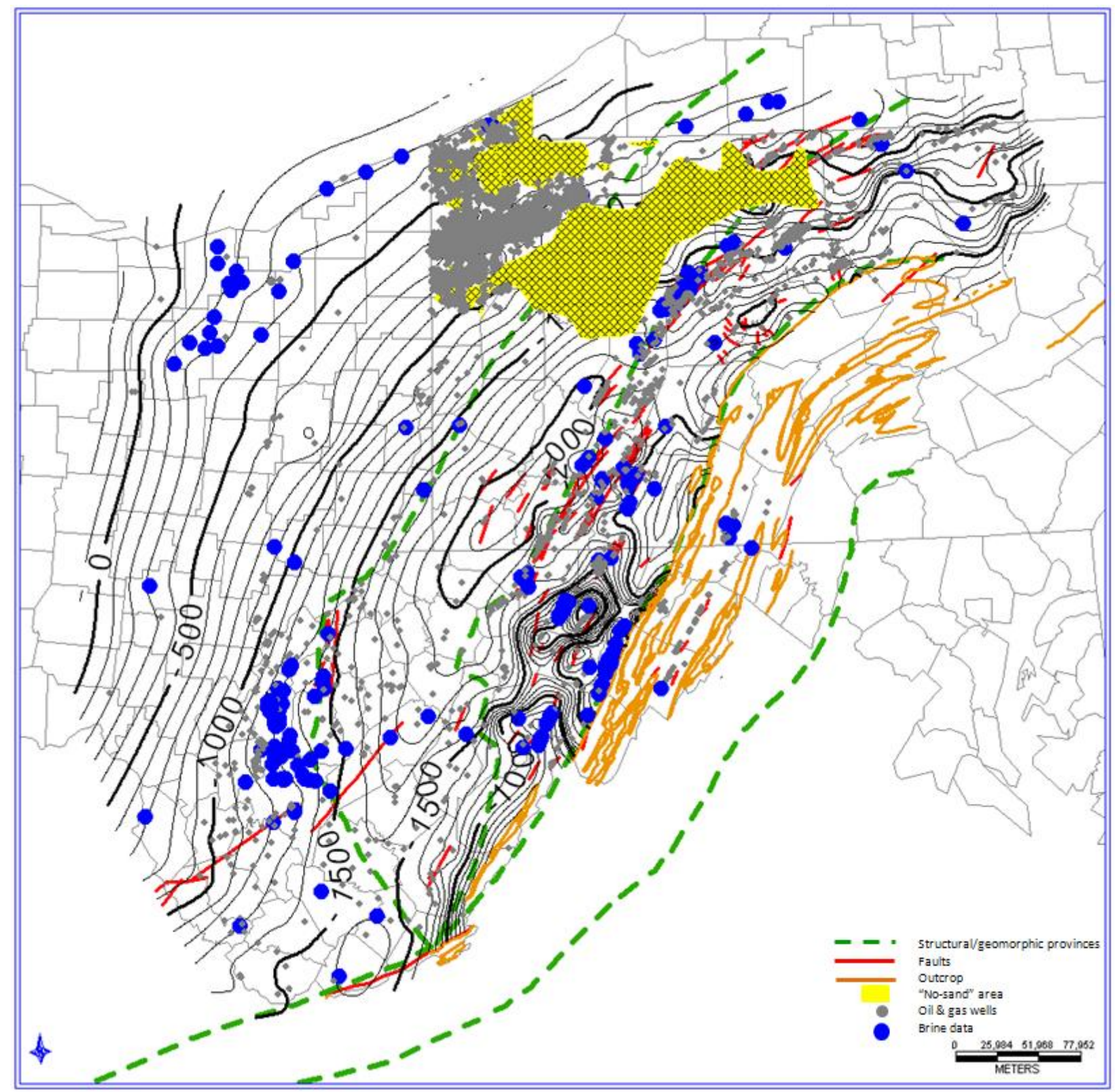

Figure 2-1. Structure on the top of the Oriskany Sandstone. Contour interval is 100 meters. 


\subsubsection{DEPTH}

A map of depth to the Oriskany was constructed to map areas suitable for supercritical $\mathrm{CO}_{2}$ injection. The Oriskany reaches maximum depths of over 2,500 meters the center of the Appalachian basin (Figure 2-2). Potential $\mathrm{CO}_{2}$ sequestration area was mapped along the 800 meter depth contour (Figure 2-3). The area was not mapped into locations were depth data were lacking. The delineated area is $139,000 \mathrm{~km}^{2}\left( \pm 1,000 \mathrm{~km}^{2}\right)$. 


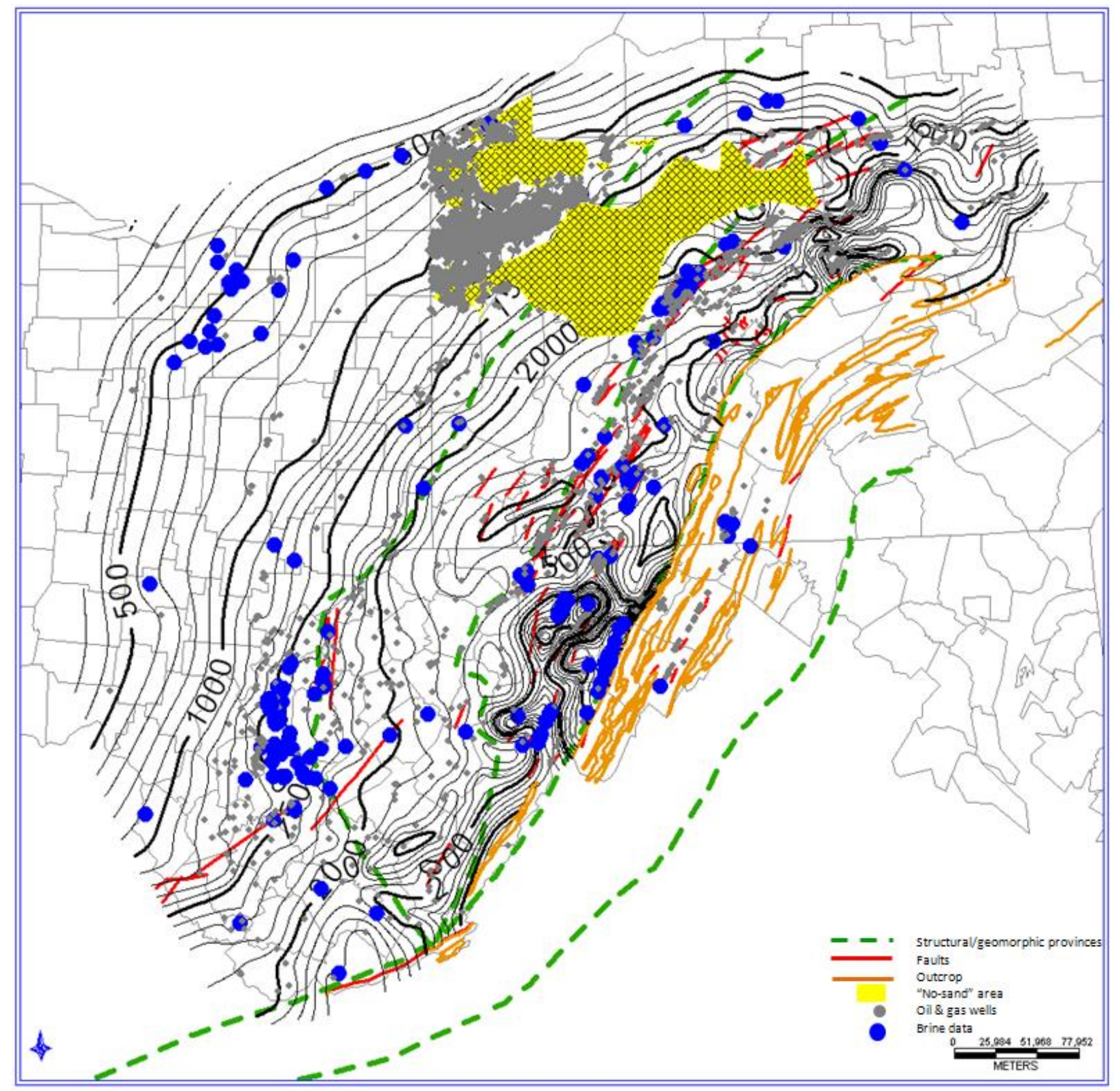

Figure 2-2. Depth to top of Oriskany Sandstone. Contour interval is 100 meters. Areas within the know outcrop belt to the east were not contoured due to lack of sufficient data to accurately depict the complex structure. 


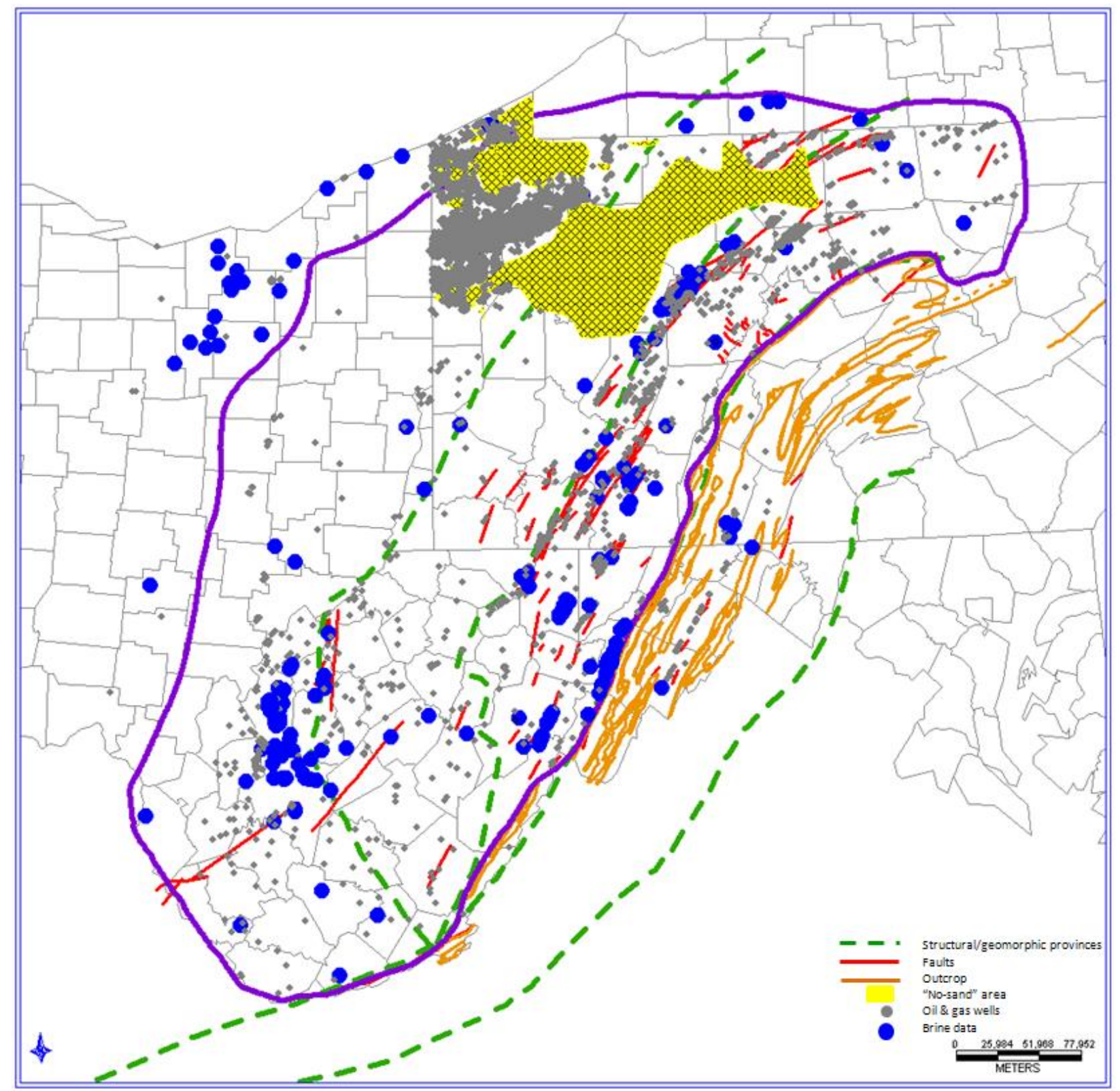

Figure 2-3. Oriskany Sandstone potential sequestration area. The purple line indicates the study area that meets the depth greater than 800 meters criteria for supercritical $\mathrm{CO}_{2}$ storage and avoids areas of known outcrop belts. 


\subsubsection{ISOPACH}

The thickness of the Oriskany varies across the Appalachian basin from zero to a thickness $\geq$ 75 meters (Figure 2-3). In the "no-sand area" in the northern Appalachian basin, the Oriskany is thin or absent due to erosion or non-deposition (Diecchio, 1985). The Oriskany is typically

thickest in the High Plateau and Eastern Overthrust Belt regions, but thins and pinches out to the west, northwest and south, where it is generally $\leq 10$ meters thick. 


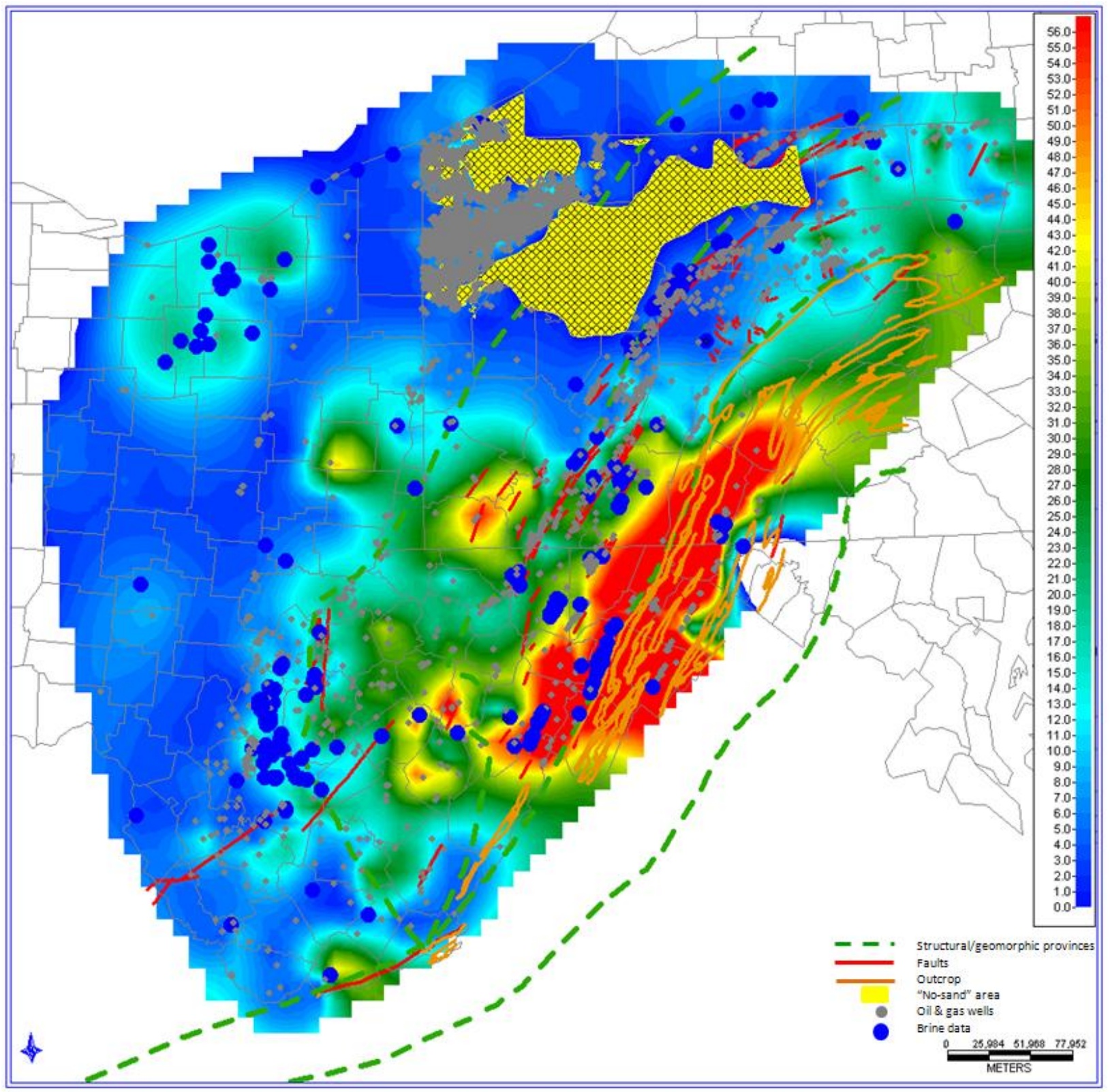

Figure 2-3. Oriskany Sandstone thickness estimate. The average thickness is 16 meters. Contour interval is 1 meter. "No-sand areas" are indicated by yellow cross-hatched. 


\section{ROCK PROPERTIES}

\subsection{METHODOLOGY}

Previously-analyzed core data were used to estimate the porosity of the Oriskany. The data were largely restricted to areas of existing oil and gas wells, requiring extrapolated across data gaps to map the study area. The core scale porosity measurements were scaled up to well scale and then to basin scale using the method described by Bachu and Underschultz (1992, 1993). The method states that the formation-scale porosity index $(\Phi)$ of the unit is the arithmetic average of the core-scale values weighted by the thickness of the unit. Since reported core porosity data represent volume-averaged values corresponding to the physical size of the sample (i.e., core plug), it does not reflect larger scale secondary porosity elements such as vugs and fractures (Bachu and Undershultz, 1992). The value was then be used to estimate the potential $\mathrm{CO}_{2}$ storage volume.

\subsection{RESULTS}

Porosity estimates were collected from published studies, as well as from producing or potential oil and gas wells (Headlee and Joseph, 1945; Herald, et al., 1962; Harper and Patchen, 1996; New York Geological Survey; and Texas Keystone; Table 1). These data consisted of 19 porosity values, for counties and individual oil and gas fields. These porosity values were assigned to the wells located within the counties or fields resulting in a total of 894 well values. Using the method of Bachu and Undershultz $(1992,1993)$ a mean porosity of $8.08 \%$ was

estimated and a map was interpolated using the minimum curvature method with Petra ${ }^{\mathrm{TM}}$ (Figure 
3-1). The Low Plateau and High Plateau of the central Appalachian basin contain the area with the lowest porosity values. 


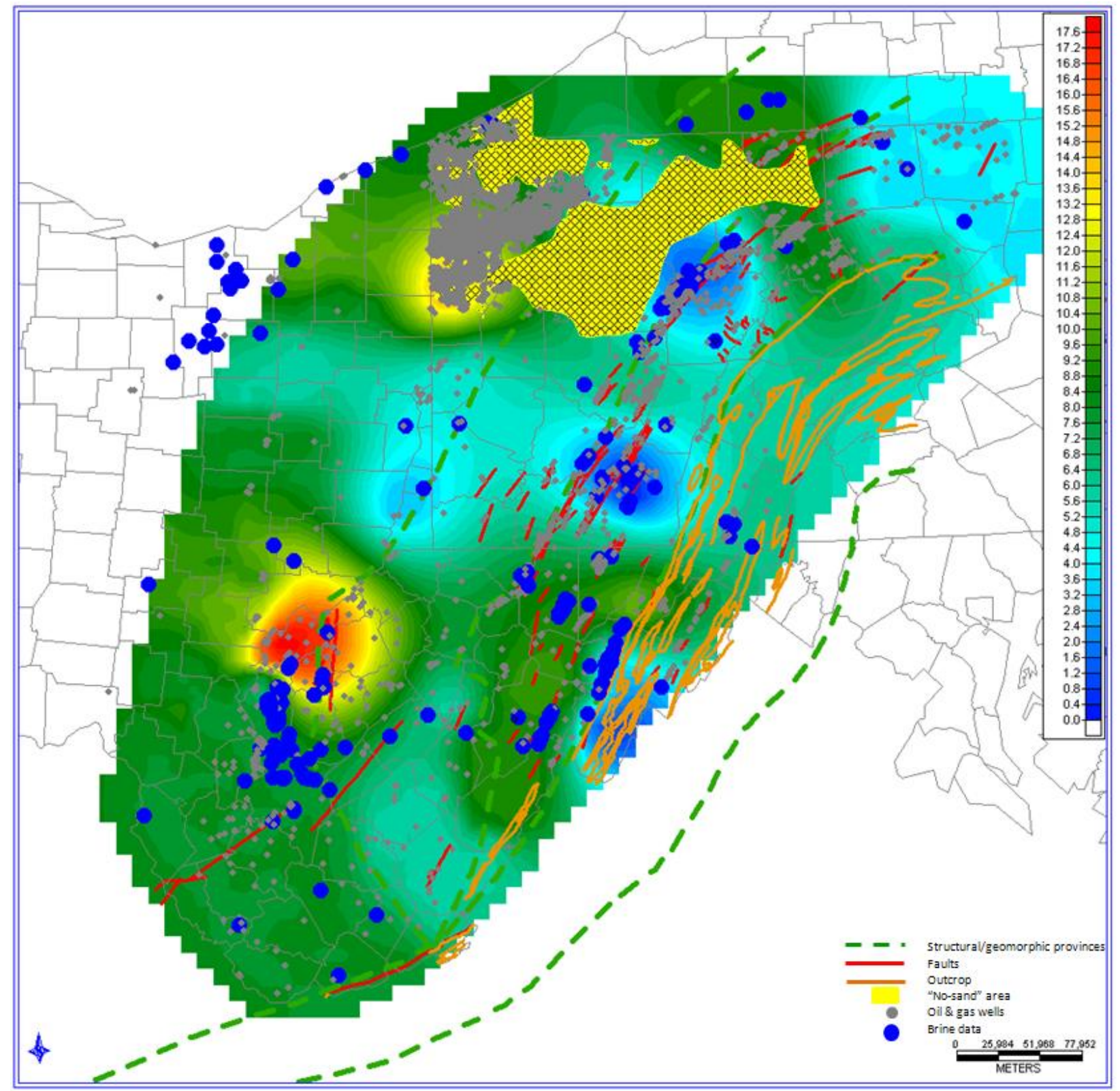

Figure 3-1. Oriskany Sandstone porosity map. Contour interval is 0.2 porosity units. 


\section{FLOW VARIABLES AND CHEMISTRY OF FORMATION WATER}

\subsection{METHODOLOGY}

\subsubsection{TEMPERATURE}

Bottom-hole temperatures (BHTs) are recorded during logging of the borehole and commonly are not at equilibrium with formation temperature and require correction.

Temperatures from shallow boreholes are generally too high, and temperatures from deep boreholes are too low (Appendix I). One method to correct for these erroneous BHTs is to plot the values versus depth, with the mean surface temperature $\left(12^{\circ} \mathrm{C}\right.$ for the Appalachian basin $)$ providing an intercept (Forster et al., 1999). Figure 4-1 shows a plot of Oriskany bottom-hole temperature versus depth for 57 wells. By comparing the regression equation between the uncorrected and corrected intercepts a correction factor can be generated. 


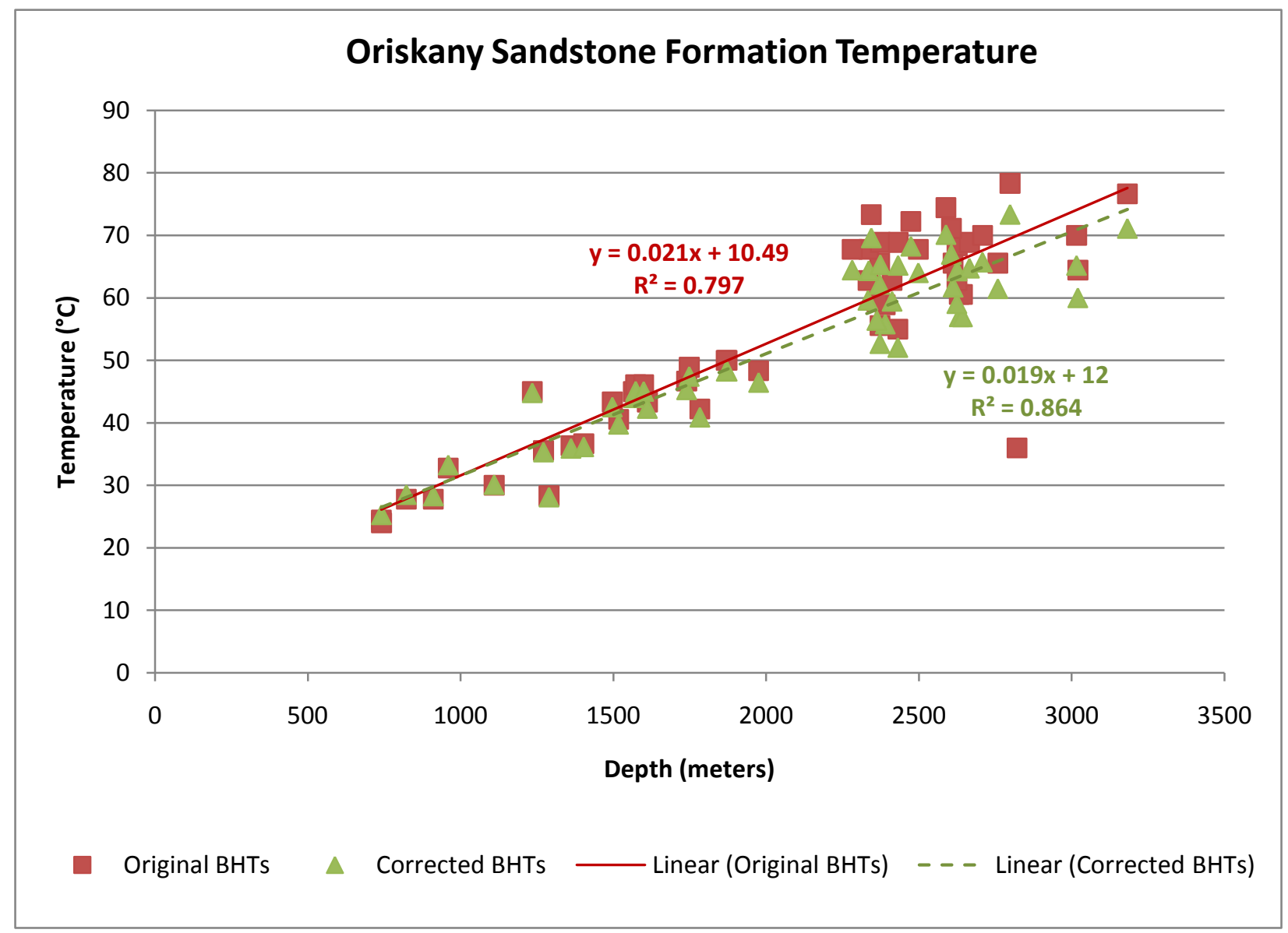

Figure 4-1. Oriskany Sandstone formation temperature $\left({ }^{\circ} \mathrm{C}\right)$ plotted against depth $(\mathrm{m})$. Data from 57 wells provided in Appendix I. 


\subsubsection{PRESSURE}

Under hydrostatic conditions, pressure increases with depth at the rate of $9.74 \mathrm{kPa} / \mathrm{m}$ for freshwater and approximately $10.71 \mathrm{kPa} / \mathrm{m}$ for brine with $145,000 \mathrm{mg} / \mathrm{L}$ TDS. Recorded pressure, like temperature, is related to both depth and burial history (Carr et al., 2005). Measured pressure values may be influenced by drawdown from nearby wells, but these data were still retained because local production is thought to have little influence on regional-scale pressure features (Bachu and Undershultz, 1995). Final shut-in pressure versus depth for 225 wells in the Oriskany is shown in Figure 4-2 (Appendix II). The hydrostatic gradient for fresh water and brine are plotted over these data to test hypotheses that the Oriskany is either overpressured or underpressured (Figure 4-2). 


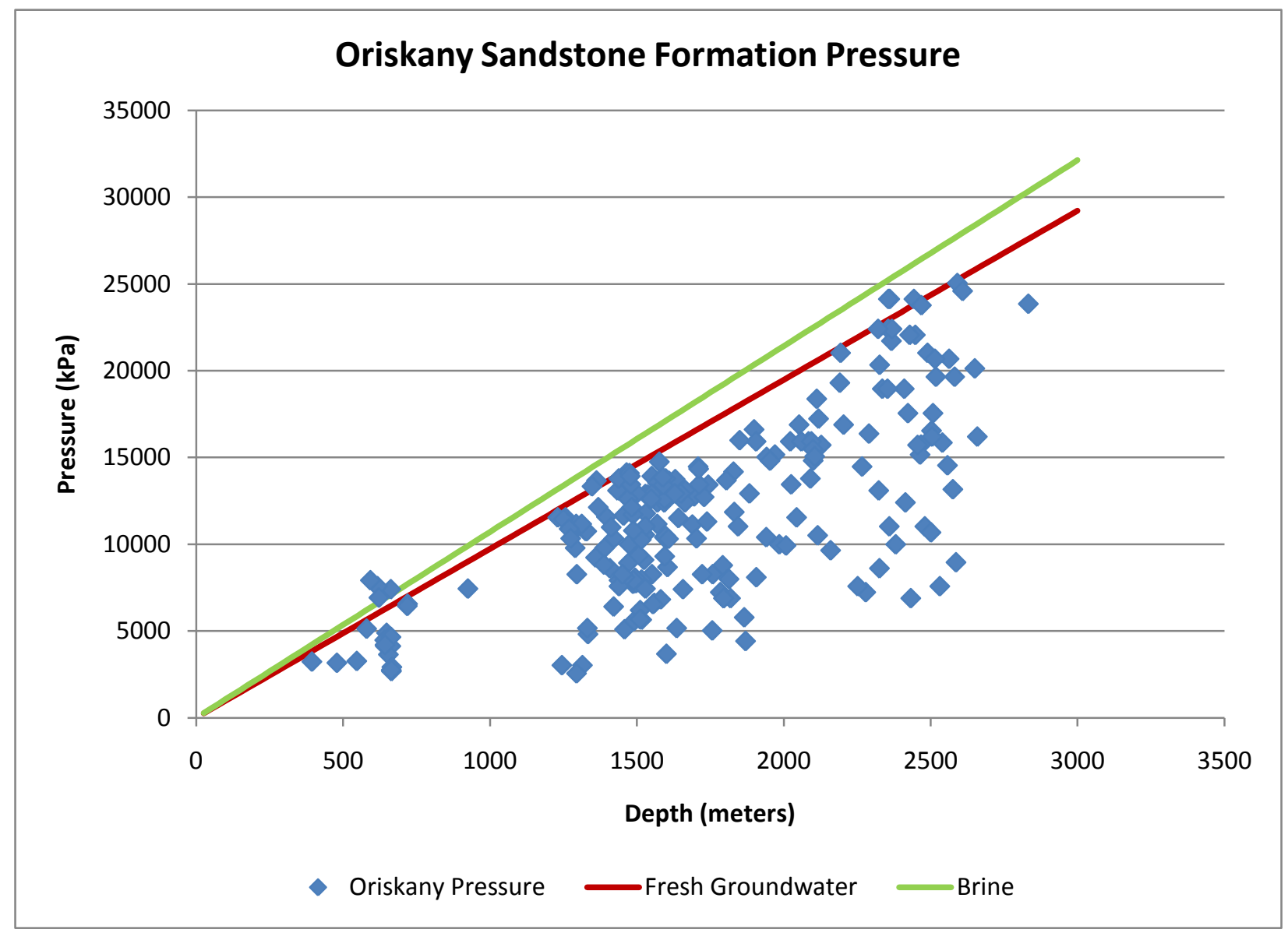

Figure 4-2. Oriskany Sandstone formation pressure (kPa) plotted against depth $(\mathrm{m})$. Red squares indicate the idealized pressure gradient for fresh groundwater (TDS <10,000 mg/L). Green triangles indicate the idealized pressure gradient for brine (TDS=145,000 mg/L). Data from 225 wells provided in Appendix II. 


\subsubsection{TOTAL DISSOLVED SOLIDS (TDS)}

Existing brine geochemical data was gathered from published and unpublished state and federal geological surveys, as well as local oil and gas companies. The data were checked for quality assurance based on the method described by Hitchon and Brulotte (1994) (Table 2). An additional ten brine samples were collected from existing oil and gas wells distributed throughout the Appalachian basin, with an attempt made to collect new sample sites in areas of data gaps (Appendix III). The location of these brine samples depended on the participation and cooperation of local oil and gas companies. The brine samples were collected according to United States Geological Survey (USGS) standards in $500 \mathrm{~mL}$ high-density polyethylene bottles that were labeled with well location, sampled formation, depth, and date (USGS, 2006).

The samples were shipped to and analyzed at the Geochemical Testing Laboratory located in Somerset Pennsylvania. Analytes included: Alkalinity, TDS, and concentrations of calcium $(\mathrm{Ca})$, sodium $(\mathrm{Na})$, magnesium $(\mathrm{Mg})$, potassium $(\mathrm{K})$, chloride $(\mathrm{Cl})$, and sulfate $\left(\mathrm{SO}_{4}\right)$. Alkalinity $\left(\mathrm{CaCO}_{3}\right)$ concentration, which includes carbonate $\left(\mathrm{CO}_{3}\right)$ and bicarbonate $\left(\mathrm{HCO}_{3}\right)$, were determined by the titrimetric method according to the Association of Official Analytic Chemists (AOAC) standards with a detection limit of $2 \mathrm{ppm} \mathrm{CaCO}_{3}$. Total dissolved solids (TDS) concentrations were measured using the American Society of Testing and Materials (ASTM) gravimetric method with a detection limit of $0.8 \mathrm{mg} / \mathrm{L}$. The Environmental Protection Agency (EPA) Method 300.0 of ion chromatography was used to measure the $\mathrm{Cl}$ and $\mathrm{SO}_{4}$ content with a detection limit of 0.03 ppm (O’Dell et al., 1993). The concentration of the cations $\mathrm{Ca}, \mathrm{Mg}, \mathrm{K}$, and $\mathrm{Na}$ were calculated using inductively coupled plasma mass spectroscopy (ICPMS) with detection limits of 50, 1.0, 30, and $5 \mu \mathrm{g} / \mathrm{L}$, respectively. 


\subsubsection{GROSS FLUID FLOW}

Darcy's law describes fluid flow in a porous medium. When it is written in terms of hydraulic head rather than pressure, it shows that the flow of formation water is driven by hydraulic gradients, density differences, and variations in temperature and chemical concentrations (Bachu, 1995b). For sedimentary basin-scale flow systems, temperature and chemical concentration differences are generally thought to be unimportant by comparison with hydraulic- (topographic) and buoyancy-driving mechanisms (Bachu, 1995a, 1995b). Buoyancy, due to density differences, can potentially play an important role by opposing and retarding the flow of formation waters driven by hydraulic-head gradients (Bachu, 1995b).

In order to analyze the flow pattern, the formation pressures were used to calculate equivalent freshwater hydraulic head, $\mathrm{H}_{\mathrm{o}}$ :

$$
H=\left(p / \rho_{o} g\right)+z \quad(\text { Formula } 1)
$$

where $\mathrm{p}$ is formation pressure, $\rho_{\mathrm{o}}=1000 \mathrm{~kg} / \mathrm{m}^{3}$ (density of freshwater), $\mathrm{g}$ is the gravitational constant $9.80665 \mathrm{~m} / \mathrm{s}^{2}$, and $\mathrm{z}$ is elevation relative to sea level (Bachu and Undershultz, 1993, 1995; Anfort et al., 2001). Formation waters in sedimentary basins become less dense as temperature increases, but denser as salinity increases. Therefore, density variations have the potential in introduce error in freshwater hydraulic head estimates (Bachu and Undershultz, 1993, 1995). An indication of the magnitude of this introduced error is given by the dimensionless driving force ratio (DFR) defined (Davies, 1987; Bachu, 1995) as:

$$
D F R=(\Delta \rho|\Delta E|) /\left(\rho\left|\Delta H_{o}\right|_{h}\right) \quad(\text { Formula 2) }
$$


where $|\Delta \mathrm{E}|$ is the magnitude of the aquifer slope, $\left|\Delta \mathrm{H}_{\mathrm{o}}\right|_{\mathrm{h}}$ is the magnitude of the horizontal component of the freshwater hydraulic-head gradient, $\Delta \rho$ is the difference between formationwater and freshwater densities. If the DFR value is greater than 0.5 , neglecting buoyancy effects will introduce significant errors in flow analysis using an equivalent head concept (Davies, 1987). However, according to Aufont, et al., (2001), the presence and direction of flow will be correct but the magnitude will be less than indicated. This is due to hydraulic gradients and buoyancy acting in opposite directions along dip. The values for $\mathrm{H}_{\mathrm{o}}$ thus calculated were mapped with Petra using the minimum curvature parameters and the resulting gradients were used to estimate the flow direction and strength.

\subsection{RESULTS}

\subsubsection{TEMPERATURE}

Figure 4-1 shows correcting for erroneous BHTs in the Oriskany to a zero-depth intercept of $12{ }^{\circ} \mathrm{C}$ (average surface temperature) to yield a linear geothermal gradient by regression of:

$$
T=0.0195 d+12 \quad \text { (Formula } 3)
$$

where $\mathrm{T}$ is in degrees Celsius and $\mathrm{d}$ is in meters. This is approximately $20^{\circ} \mathrm{C} / \mathrm{km}$, low for cratonic rocks, typically 25 to $30^{\circ} \mathrm{C} / \mathrm{km}$. Hitchon (1984) attributes low geothermal gradients to topographically-controlled hydrodynamic flow. The newly calculated geothermal gradient values were used to generate a map with Petra of subsurface temperature of the Oriskany using the minimum curvature method (Figure 4-3). The resulting grid will be used in estimating the solubility trapping capacity of the Oriskany. 


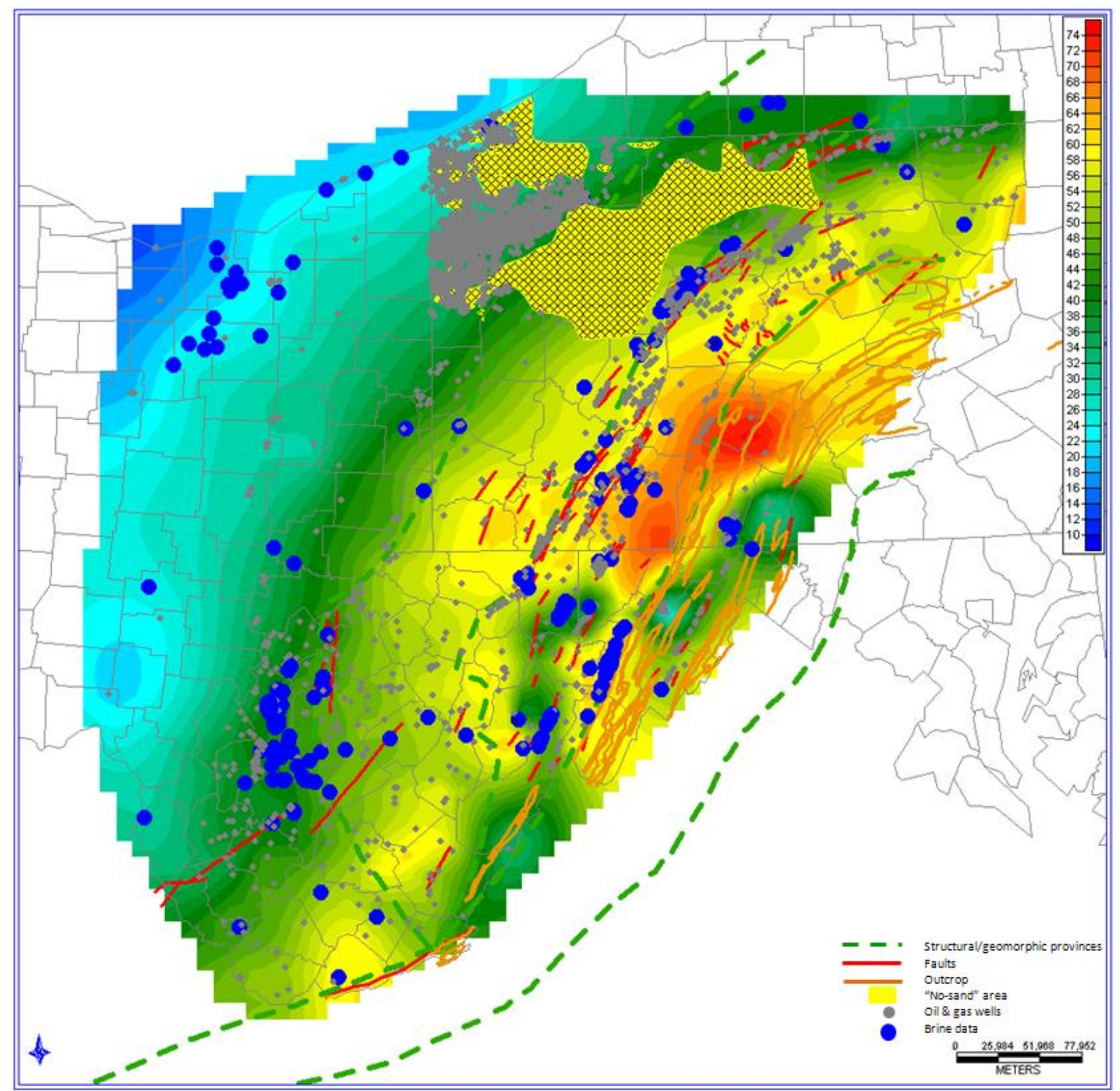

Figure 4-3. Oriskany Sandstone formation temperature $\left({ }^{\circ} \mathrm{C}\right)$ using the newly calculated gradient. Contour interval is $2^{\circ} \mathrm{C}$. 


\subsubsection{PRESSURE}

Final shut-in pressure recorded from gas wells of the Oriskany (based on $n=225$ wells) is significantly below the expected hydrostatic gradient for fresh groundwater. Pressure plotted against depth indicates that the Oriskany is underpressured (Figure 4-4). This underpressure below hydrostatic for either fresh or average-salinity water (lines on Figure 4-2) may be due to drawdown from nearby wells and/or lack of sufficient shut-in time to reach pressure equilibrium. However, a few cases $(<5 \%)$ of overpressure were observed but the Oriskany reservoirs at a regional scale appear to be underpressured. Abnormally low reservoir pressures can be caused by gaseous diffusion and gas shrinkage in reservoirs that have been uplifted or otherwise cooled (Russell, 1972; Belitz and Bredehoeft, 1988; Bachu and Undershultz, 1995). The High Plateau of the central Appalachian basin is the area with the highest pressure values. 


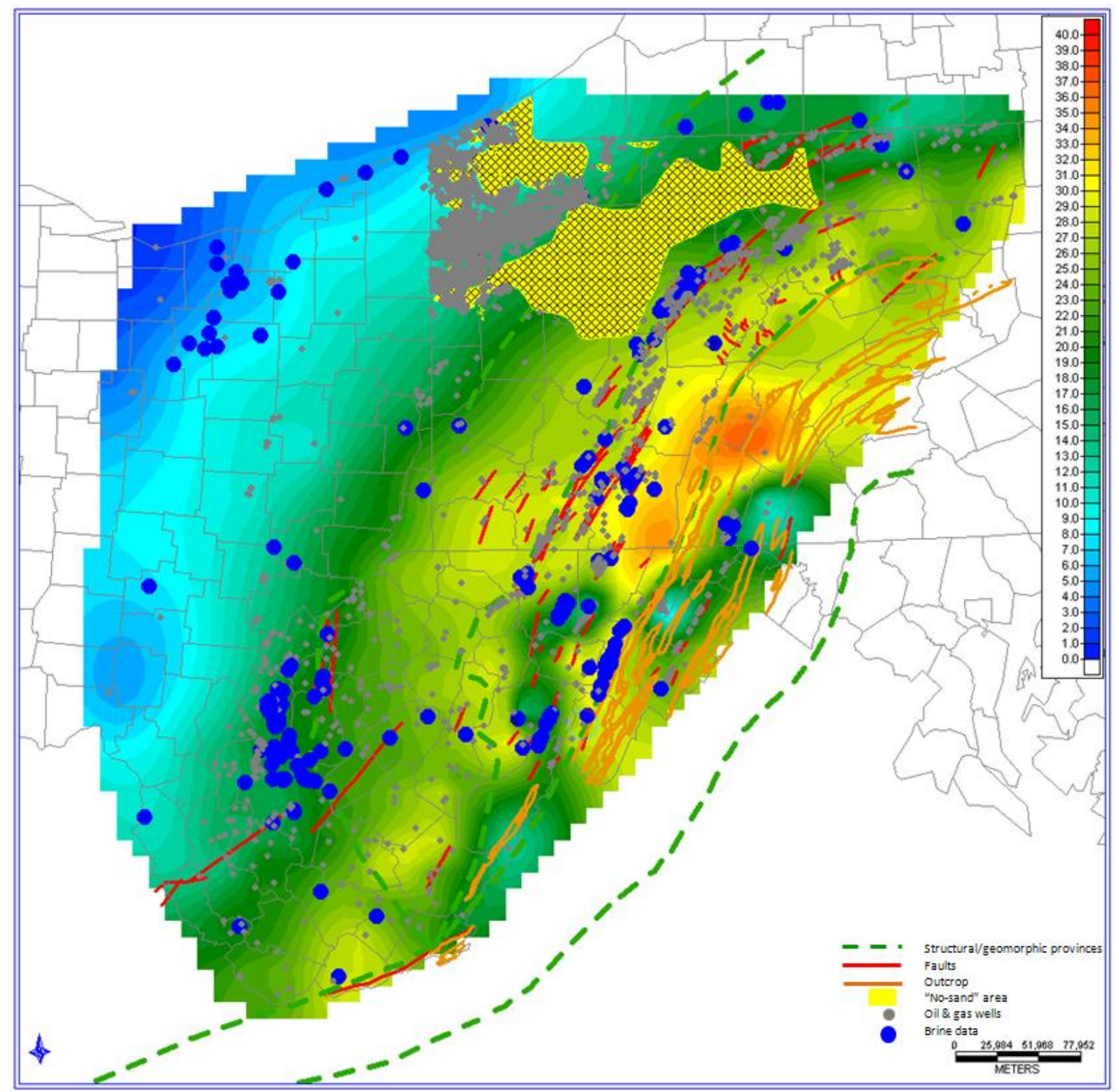

Figure 4-4. Oriskany Sandstone formation pressure $(\mathrm{kPa})$ at top of structure using the newly calculated pressure gradient. Contour interval is $1 \mathrm{kPa}$. 


\subsubsection{TOTAL DISSOLVED SOLIDS (TDS)}

Oriskany brine geochemical data were compiled from published and unpublished sources (Stout, et al., 1932; Price, et al., 1937; Hoskins, 1947; Poth, 1962; Kelley, et al., 1973; Woll, 1978; Dresel, 1985; Lloyd and Reid, 1990; Chesapeake Energy; and NatCarb). Additional brine samples were collected from ten existing oil and gas wells and storage fields distributed throughout the Appalachian basin. Across the extent study area, the TDS ranges from fresh $(\mathrm{TDS}<10,000 \mathrm{mg} / \mathrm{L})$ to brine (TDS $>300,000 \mathrm{mg} / \mathrm{L})($ Figure 4-5). The brines are concentrated in the structural lows at the center of the basin, while the relatively low TDS concentrations are associated with the outcrop areas to the east and the west.

Recharge of meteoric waters into saline brines can dilute salinity and enhance methanogensis (Martini et al., 1998; McIntosh et al., 2002). Thermogenic gas, on the other hand, is generated by the thermal degradation of organic material at depth and is typically associated with saline brines (McIntosh and Martini, 2005). Formation waters associated with microbial gas generally have low $\mathrm{Ca} / \mathrm{Mg}$ ratios $(<1.5)$ as a result of calcite precipitation induced by microbial methanogenesis (Martin et al., 1998). Low $\mathrm{Ca} / \mathrm{Mg}$ ratios can also be used to infer freshwater incursion. The ratio of calcium concentration to magnesium concentration for the Oriskany across the Appalachian basin is generally less than ten, and even lower $(<5)$ in the recharge and outcrop areas to the east and west (Figure 4-6). The ratio is as high as 30 in the northeast area of the basin. 


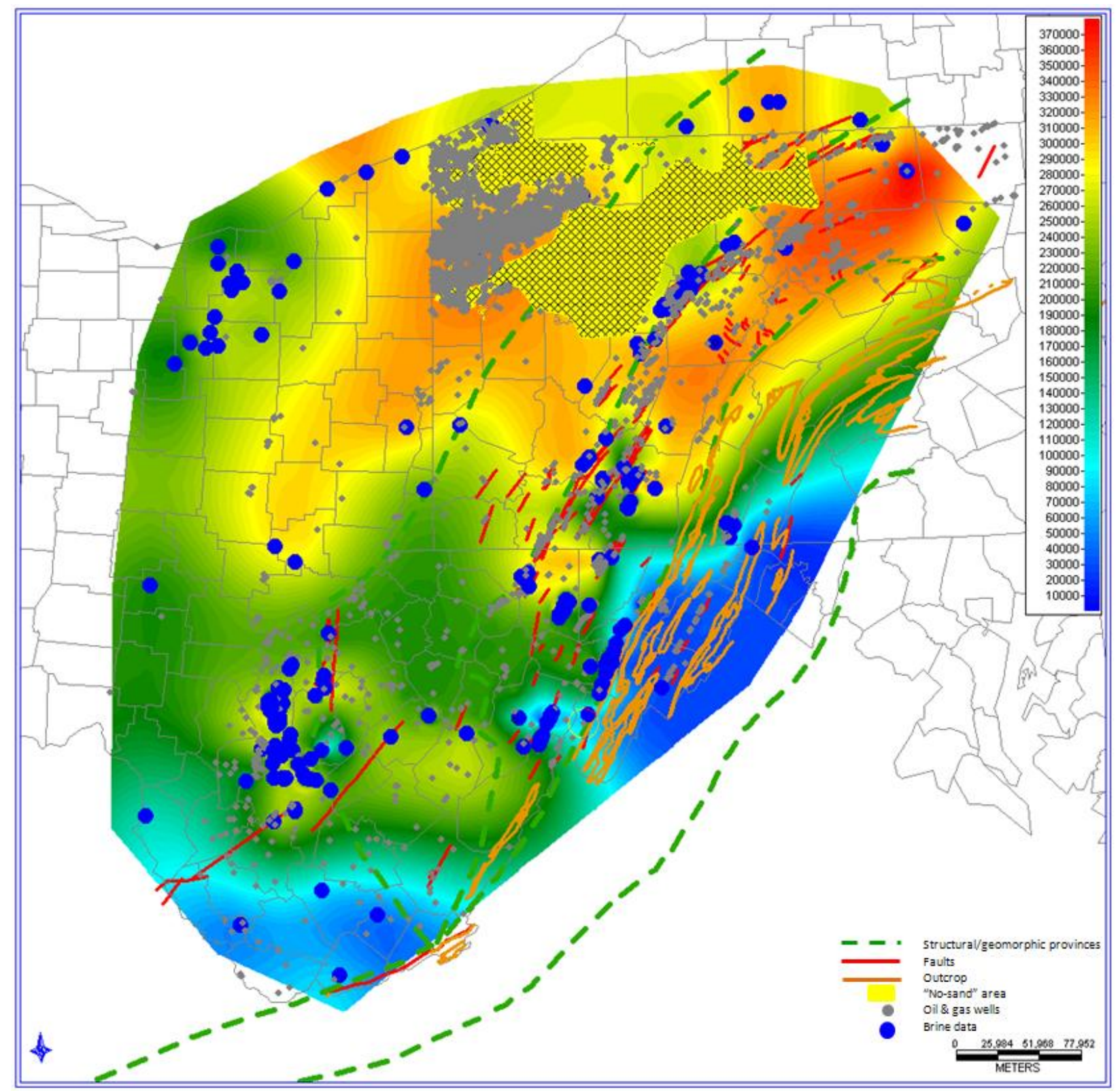

Figure 4-5. Oriskany Sandstone TDS (mg/L) map. Contour interval is 5,000 mg/L. 


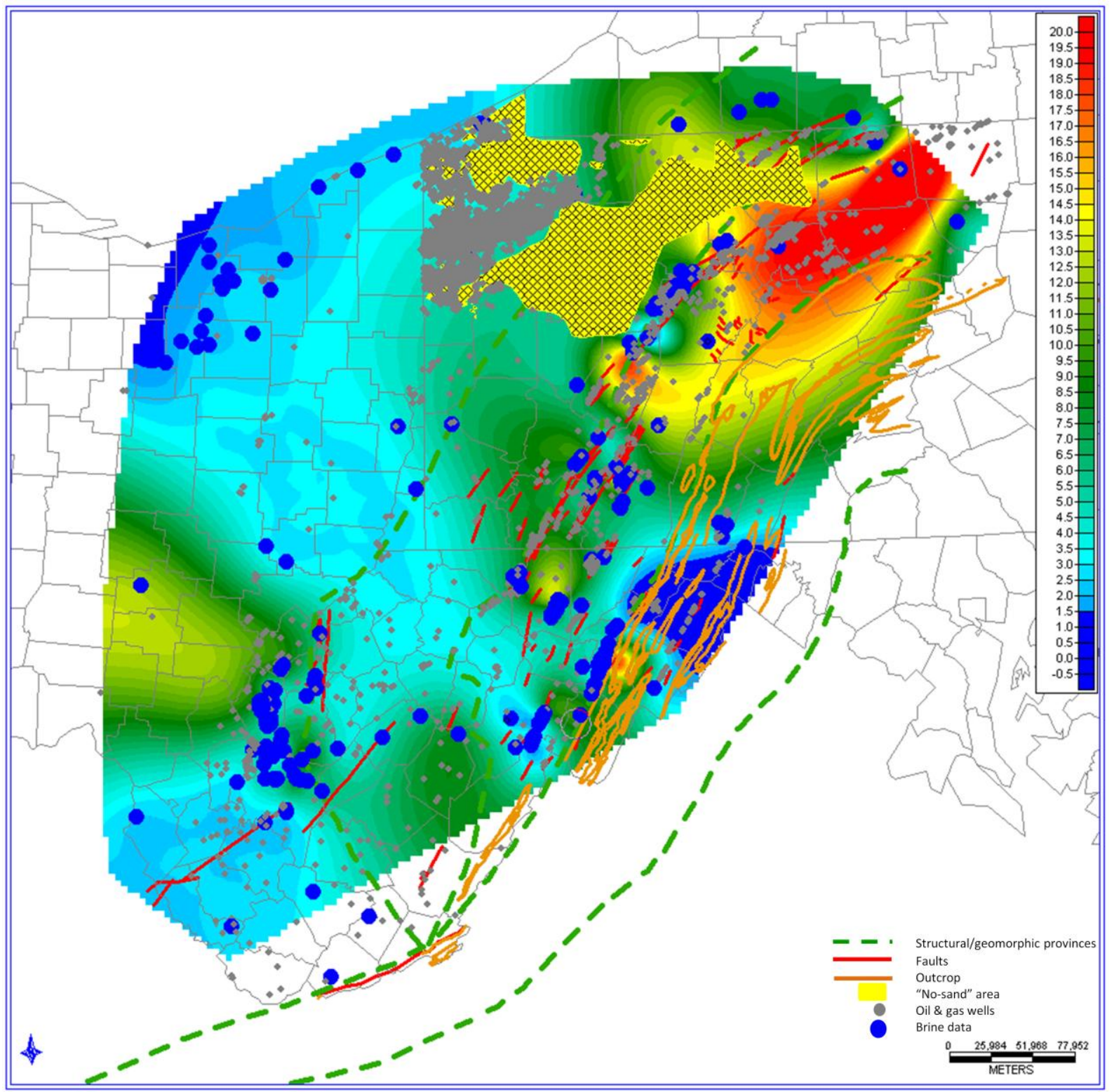

Figure 4-6. Oriskany Sandstone $\mathrm{Ca} / \mathrm{Mg}$ concentration ratio map. Contour interval is 0.5 . Values $<1.5$ indicate possible freshwater incursion. 


\subsubsection{GROSS FLUID FLOW}

Formation pressure was used to calculate equivalent freshwater hydraulic head $\mathrm{H}_{\mathrm{o}}$ (Formula 1). Use of freshwater hydraulic heads in the flow analysis of variable-density formation waters may introduce significant errors, depending on the interaction between the potential and buoyancy forces driving the flow (Bachu and Undershultz, 1993, 1995). Density values were calculated from salinity, temperature, and pressure using the relationships published by Gill (1982)(Appendix IV; Figure 4-7). Across the extent of the Oriskany the density ranges from approximately fresh water $\left(1,030 \mathrm{~kg} / \mathrm{m}^{3}\right)$ to a density of $1,300 \mathrm{~kg} / \mathrm{m}^{3}$. The formation water with the highest density is concentrated in the Oriskany structural lows at the center of the basin. The formation water with the lowest density is associated with the outcrop area to the east and the subcrop or pinch-out area to the west.

An indication of the significance of this introduced error is given by the dimensionless driving force ratio (DFR) (Formula 2). If the DFR value is greater than 0.5, neglecting buoyancy effects will introduce significant errors in flow analysis (Davies, 1987). Within the Oriskany the values were generally much less than 0.5 , with the exception of two areas located in southcentral Pennsylvania. Hydraulic heads (Figure 4-8) range from over 1,000 $\mathrm{m}$ in the deeper part of the basin to less than $250 \mathrm{~m}$ at the potential recharge area to east and the potential discharge area to the west. 


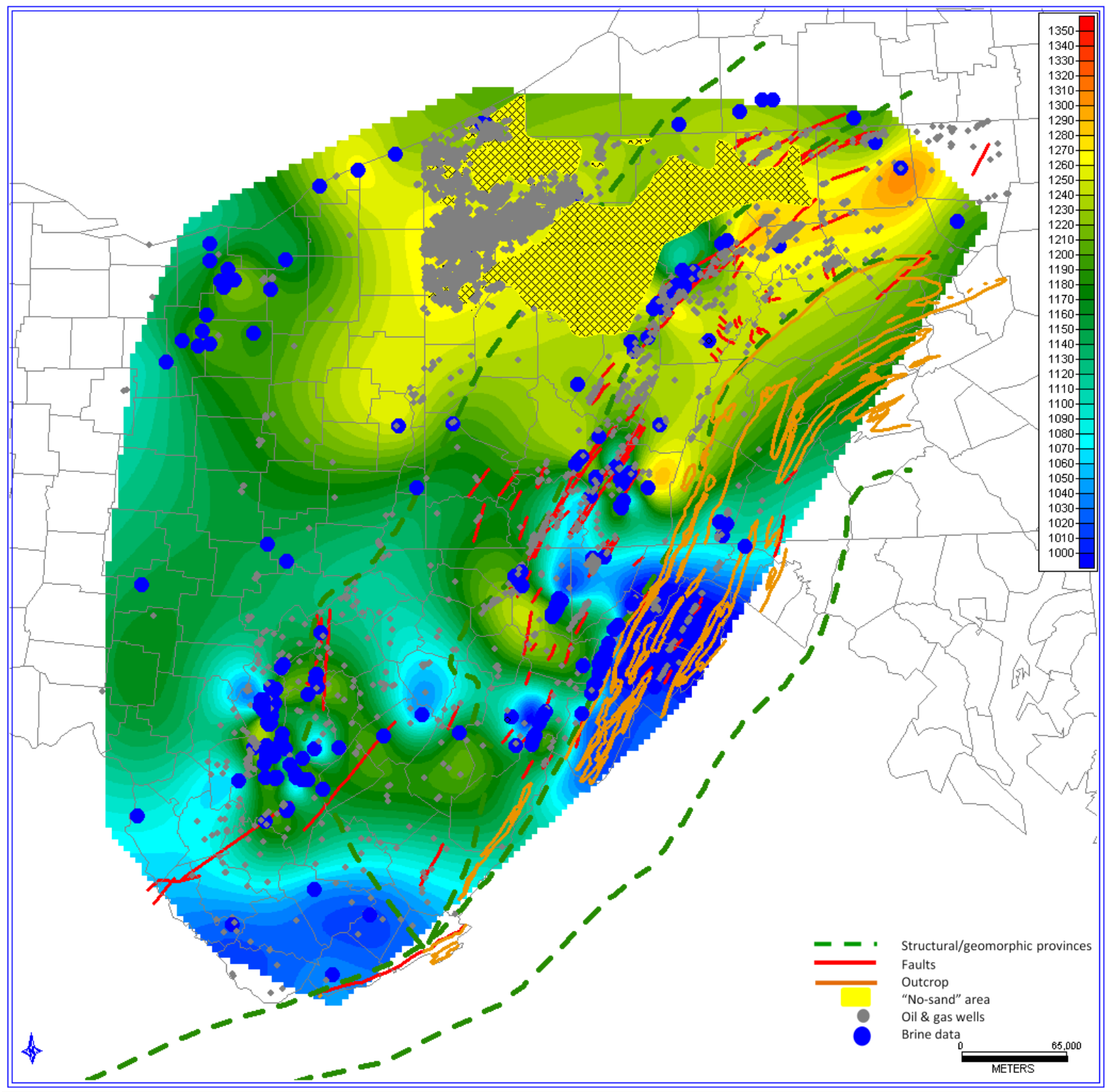

Figure 4-7. Oriskany Sandstone formation water density map. Contour interval is $10 \mathrm{~kg} / \mathrm{m}^{3}$. 


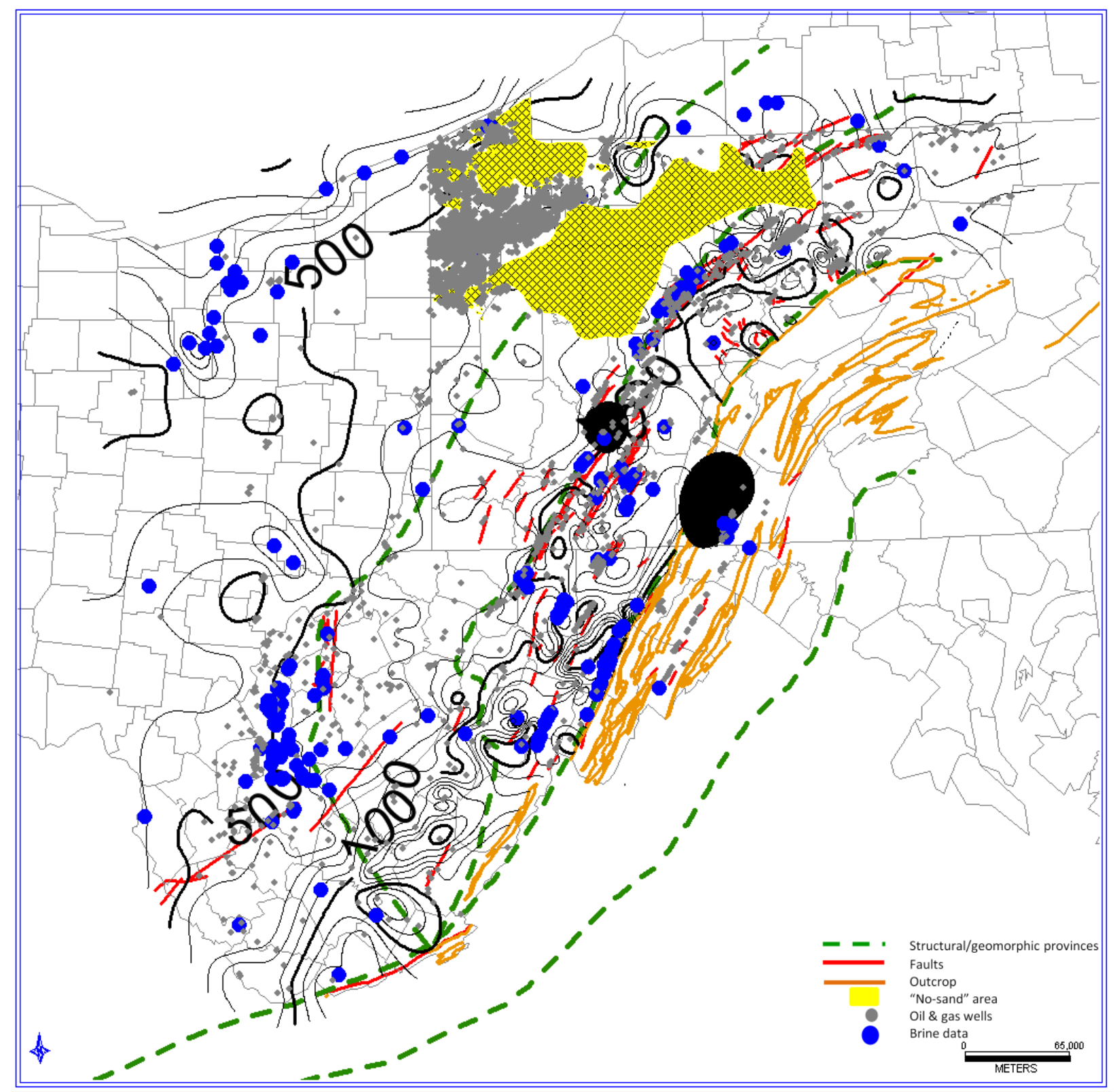

Figure 4-8. Oriskany Sandstone equivalent hydraulic head contours with areas indicated in black in which DFR values exceed 0.5. Contour interval is 500 meters. 


\section{ANALYSIS OF RESULTS}

\subsection{BASIN FRAMEWORK}

The Oriskany dips toward the center of the basin, a trend that is consistent with the preserved northeast-southwest central axis. The Oriskany shallows toward the outcrop area to the east along the Allegheny Front and Eastern Overthrust Belt and toward the Cincinnati Arch toward the west. The Oriskany is typically thickest, over 75 meters, in the Eastern Overthrust Belt and the High Plateau and thins, to a thickness less than 10 meters, toward the northwest, west, and south. Using the depth and isopach data the volume estimate of approximately 2,188 $\mathrm{km}^{3}$ will be used to calculate a total Oriskany $\mathrm{CO}_{2}$ storage capacity

\subsection{ROCK PROPERTIES}

The average $8.08 \%$ porosity value calculated for this study is consistent with the value calculated by Dilmore and others (2008) for the USDOE. This value indicates that the Oriskany has the potential to provide adequate porosity for the injection of supercritical $\mathrm{CO}_{2}(\mathrm{Bachu}$, et al., 2007). The areas of the Appalachian basin that had the lowest estimated porosity values were the areas of greatest depth $(>2,000 \mathrm{~m} \mathrm{MSL})$.

\subsection{FLOW VARIABLES AND CHEMISTRY OF FORMATION WATER}

The temperature data was corrected for erroneous BHTs that are often encountered during drilling, and are therefore directly related to depth. There was no indication that any temperature anomalies existed in the Oriskany before processing. The geothermal gradient for the Oriskany Sandstone $\left(\sim 20^{\circ} \mathrm{C}\right)$ is lower than that expected for cratonic rocks $\left(25-30^{\circ} \mathrm{C}\right)$ (Hitchon, 1984). The pressure values indicate that the Oriskany is underpressured. This underpressuring is an 
indication of the integrity and longevity of the overlying confining layer which will serve as a vertical seal for sequestered $\mathrm{CO}_{2}$ (Puckette and Al-Shaieb, 2003). There is some indication that drawdown from nearby wells and insufficient shut-in time may have an effect on some wells within the Oriskany study area. The High Plateau of the central Appalachian basin is the area with the highest pressure values, which is consistent with the suggestion of Russell (1972) that correlates high pressure values not only with depth but also deformation.

The TDS concentrations of the Oriskany formation fluids range from freshwater to dense brine. The brine samples were characterized by large differences between the reported TDS concentrations from neighboring wells within the same gas field. The cause of these differences may be related to areal, vertical, and temporal variability, errors introduced from sampling procedures, or to varying methods of chemical analysis (Jorgensen, et al., 1993). The dense brines were concentrated in the Oriskany structural lows in the center of the basin and to the north. The relatively lower TDS concentrations are at the outcrop area to the east and the subcrop area to the west. This trend would seem to indicate that any mixing of formation water with meteoric water occurs only along the outcrop and subcrop margins or along fault traces. The low $\mathrm{Ca} / \mathrm{Mg}$ ratios along the outcrop and subcrop margins can also be used to infer freshwater incursion (Martin et al., 1998). The distribution of freshwater hydraulic head shows the expected trends of northwestward and southeastward flow from the basin center toward the western subcrop area and the eastern outcrop area and further substantiates the previous assumption. 


\section{INTERPRETATION}

The Oriskany Sandstone of the Appalachian basin is a widely distributed saline aquifer which has produced large quantities of hydrocarbons and is used extensively for storage of natural gas. Oriskany gas storage fields have the capability to store/deliver more natural gas than storage fields in any other formations within the northern Appalachian basin (American Gas Association, 2001). At least 32 gas storage fields are found within the Oriskany, with a combined storage capacity approaching 1 trillion cubic feet (TCF). Many of these storage fields have been in operation since the 1950's attesting to the ability of these fields and seals to maintain long-term containment (AGA, 2001). This indicates that at the local level the Oriskany has the necessary volume, porosity, and containment characteristics for geologic storage of $\mathrm{CO}_{2}$ (Cook and Benson, 2005; Czernichowski-Lauriol et al., 2006; Bachu et al., 2007; Dilmore et al., 2008).

Using published and unpublished data of rock characteristics, pressure, temperature, and formation water geochemistry along with new brine samples were used to map the regional-scale hydrogeological regime and its relation to the migration of hydrocarbons and geologic $\mathrm{CO}_{2}$ sequestration potential. Basin-scale fluid flow of the Oriskany formation waters is generally controlled by salinity differences and by differences in structural elevation. The flow pattern is substantiated by the salinity distributions and water geochemistry, with relatively lower salinity at recharge to the east and discharge to the west due to mixing with fresh meteoric water and higher salinity between the recharge and discharge zones. The basin-scale flow pattern is also substantiated by the distribution of oil and gas fields that occur in the central Appalachian basin; the major productive gas fields occur at the boundary between lower salinity and are typically 
absent in areas of higher salinity. It is believed that hydrocarbon distribution is influenced by basinal variations in buoyancy and entrainment by the formation water flow (Hitchon, 1984).

Long-term lateral containment of large-scale $\mathrm{CO}_{2}$ injection appears to be associated in the Oriskany with convergent flow located in the eastern Appalachian basin. Storage capacity for the Oriskany saline formation is estimated by the equation:

$$
G_{c o 2}=A h_{g} \phi_{t o t} \rho E \quad(\text { Formula } 4)
$$

$\mathrm{G}_{\mathrm{CO} 2}$ is the estimate of total saline formation storage capacity in kilograms, $\mathrm{A}$ is the area of basin greater than 800 meters in depth, $\mathrm{h}_{\mathrm{g}}$ is the average thickness of formation at depths greater than 800 meters, $\phi_{\text {tot }}$ is the average formation-scale porosity for thickness $h_{g}(8.08 \%), \rho$ is the density of $\mathrm{CO}_{2}$ at pressure and temperature that represents storage conditions for saline formation averaged over $h_{g}\left(800 \mathrm{~kg} / \mathrm{m}^{3}\right.$ at $\mathrm{P}=18.01 \mathrm{MPa}$ and $\left.\mathrm{T}=43.29^{\circ} \mathrm{C}\right)$, and $\mathrm{E}$ is the storage efficiency factor that reflects a fraction of total pore volume filled by $\mathrm{CO}_{2}$ (USDOE estimations of $\mathrm{E}$ are a low of 0.01 and a high of 0.04 ).

Oriskany isopach and porosity grids were generated using Petra's minimum curvature method and a 10,000 by 10,000 meter grid size. These grids were then used to perform a grid-togrid calculation to estimate the available volume within the potential $\mathrm{CO}_{2}$ sequestration area (Figure 6-1). Grid-to-grid calculations were then performed using the constants for density of supercritical $\mathrm{CO}_{2}\left(800 \mathrm{~kg} / \mathrm{m}^{3}\right)$ and the storage efficiency factors (0.01 and 0.04) (Figures 6-2 and 6-3). The result is a storage resource estimate of 1.246 to 4.983 gigatonnes of $\mathrm{CO}_{2}$. 


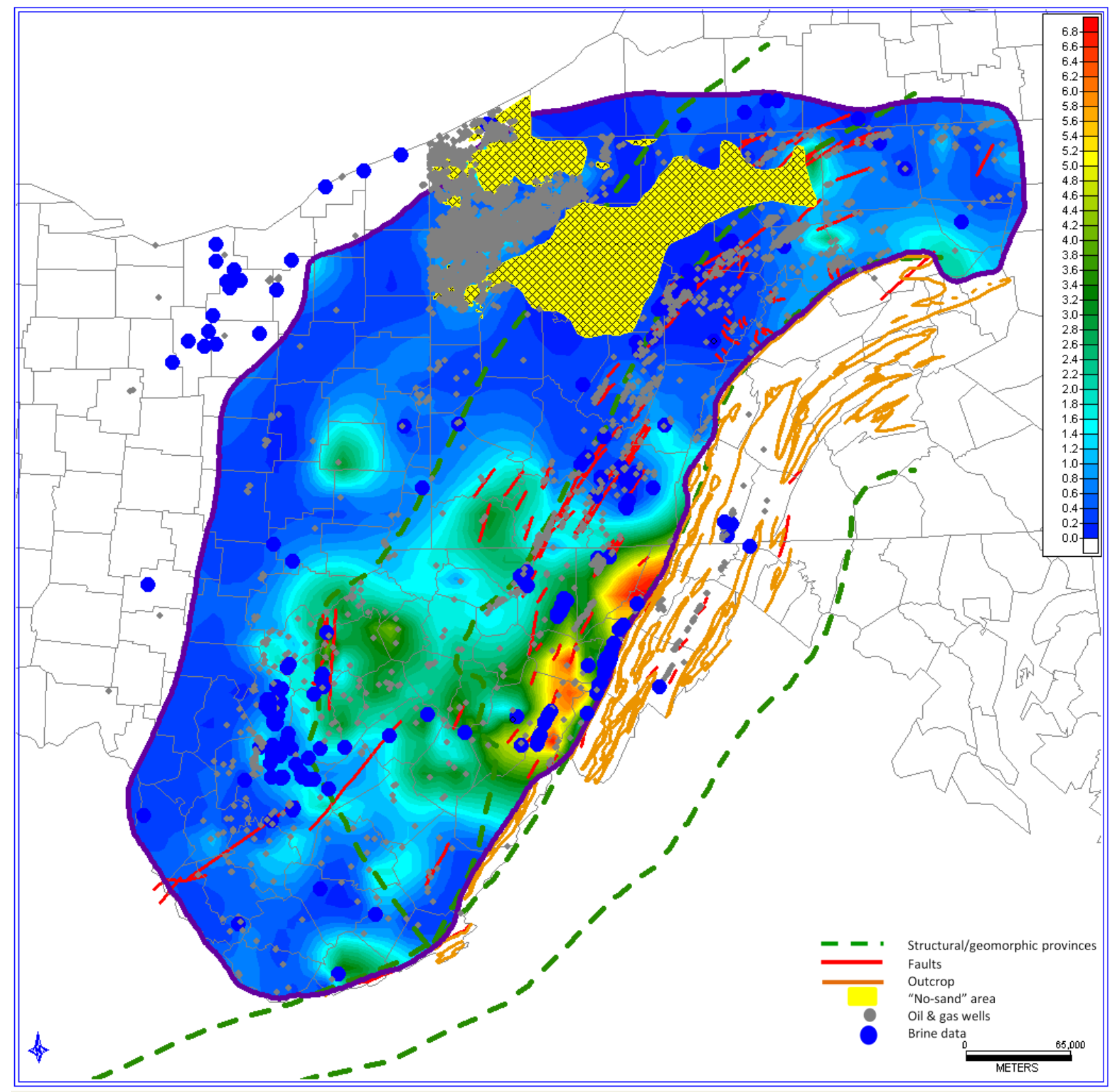

Figure 6-1. Oriskany Sandstone estimated pore volume map. Contour interval is $0.2 \mathrm{~km}^{3}$ per $100 \mathrm{~km}^{3}$. 


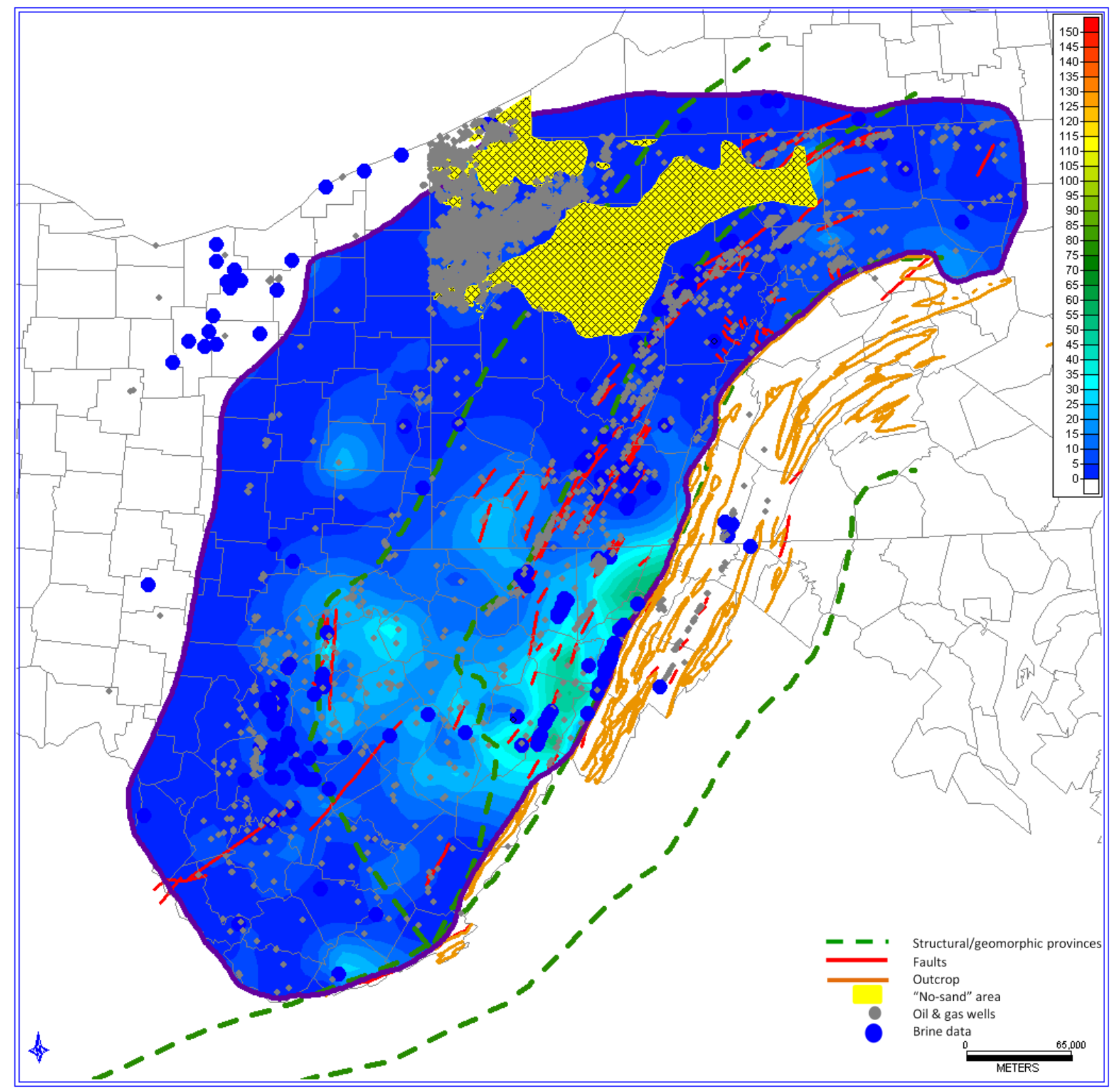

Figure 6-2. Oriskany Sandstone total storage capacity estimate using the low storage efficiency factor 0.01 . Contour interval is $5 \mathrm{~kg} / \mathrm{m}^{3}$. 


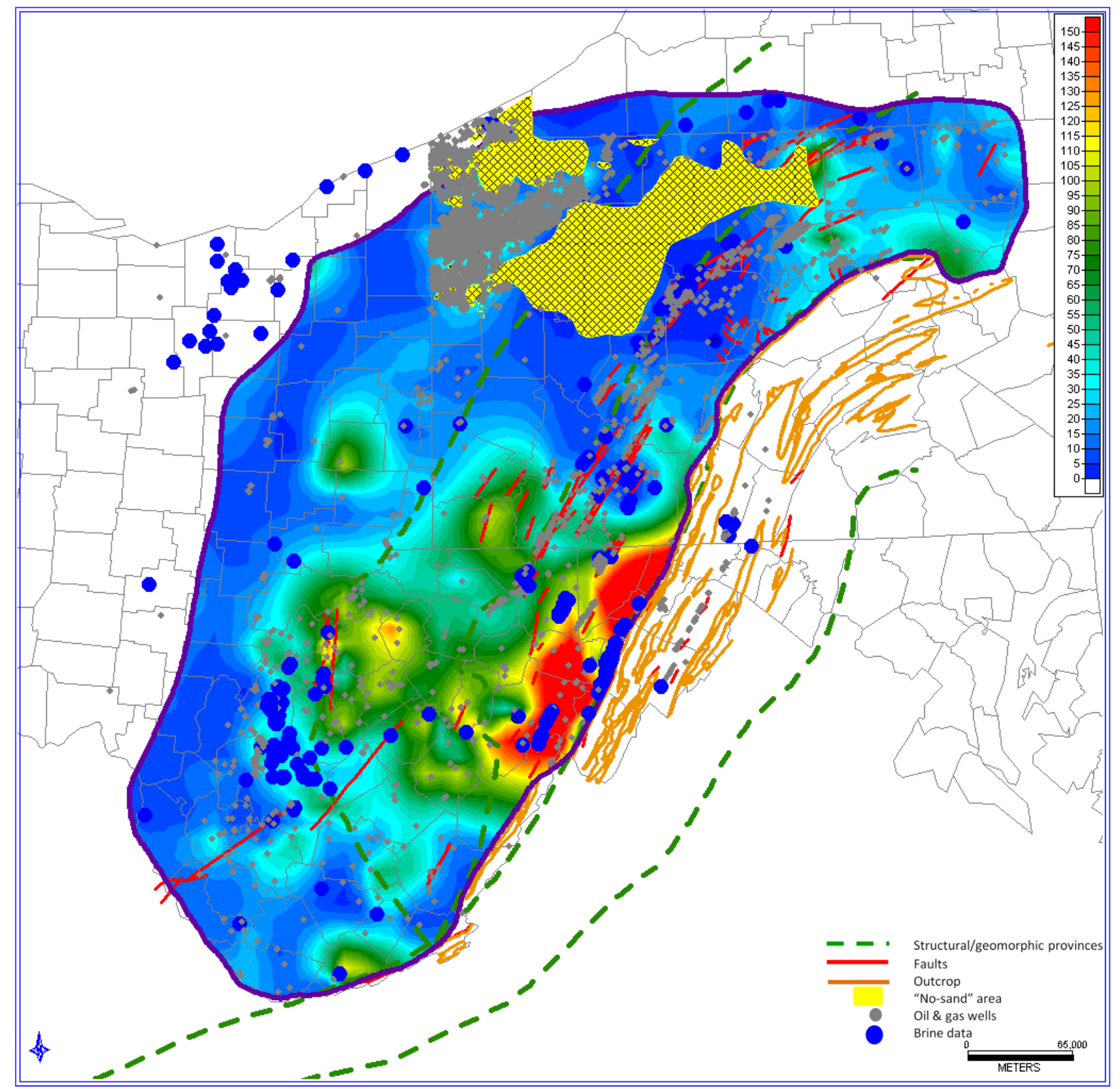

Figure 6-3. Oriskany Sandstone total storage capacity estimate using the high storage efficiency factor of 0.04 . Contour interval is $5 \mathrm{~kg} / \mathrm{m}^{3}$ 
Using the method described by Dilmore et al. (2008) the solubility trapping capacity of the Oriskany saline formation can be estimated by the following equation:

\section{$\mathrm{CO}_{2}=v E \phi \delta m \mathrm{CO}_{2} \mathrm{M} \quad($ Formula 5)}

$\mathrm{CO}_{2}$ is the estimate of total mass of $\mathrm{CO}_{2}$ in grams that can be trapped, $v$ is the total volume of the formation in $\mathrm{km}^{3}$, E is the storage efficiency factor, $\phi$ is the estimated mean porosity, $\delta$ is the density of $\mathrm{CO}_{2}$ saturated brine in $\mathrm{kg} / \mathrm{km}^{3}, \mathrm{mCO}_{2}$ is the concentration of $\mathrm{CO}_{2}$ dissolved in the brine in $\mathrm{mol} / \mathrm{kg}$, and $\mathrm{M}$ is the molar mass of $\mathrm{CO}_{2}$ in $\mathrm{g} / \mathrm{mol}(44.01 \mathrm{~g} / \mathrm{mol})$.

The previous grid-to grid calculation for estimated pore volume within the potential $\mathrm{CO}_{2}$ sequestration area was used with a value of $155.75 \mathrm{~km}^{3}$. A grid was generated for the density of $\mathrm{CO}_{2}$ saturated brine $(\delta)$ using the polynomial fit (Table 3) determined by Dilmore et al. (2008) to correlate temperature, pressure, and brine chemistry. A concentration of $\mathrm{CO}_{2}$ dissolved in brine grid was also generated using the polynomial fit (Table 4) to correlate temperature to the formation $\mathrm{CO}_{2}$ concentration using the parameters described above. Grid-to-grid calculations were performed to estimate the potential dissolved $\mathrm{CO}_{2}$ storage capacity at the low and high storage efficiency factors $(0.01$ and 0.04$)$ (Figures 6-4 and 6-5). The result is a solubility storage capacity estimate of 0.04 to 0.17 gigatonnes of $\mathrm{CO}_{2}$.

At a regional scale, the Oriskany Sandstone appears to have the characteristics to be considered a geologic storage resource for storage of $\mathrm{CO}_{2}$ supercritical fluids (Cook and Benson, 2005; Czernichowski-Lauriol et al., 2006; Bachu et al., 2007; Dilmore et al., 2008). However, site selection will require thorough evaluation of the formation. Such target sites include zones 
of high porosity and high permeability in areas of convergent hydrogeologic flow due to differences in salinity. 


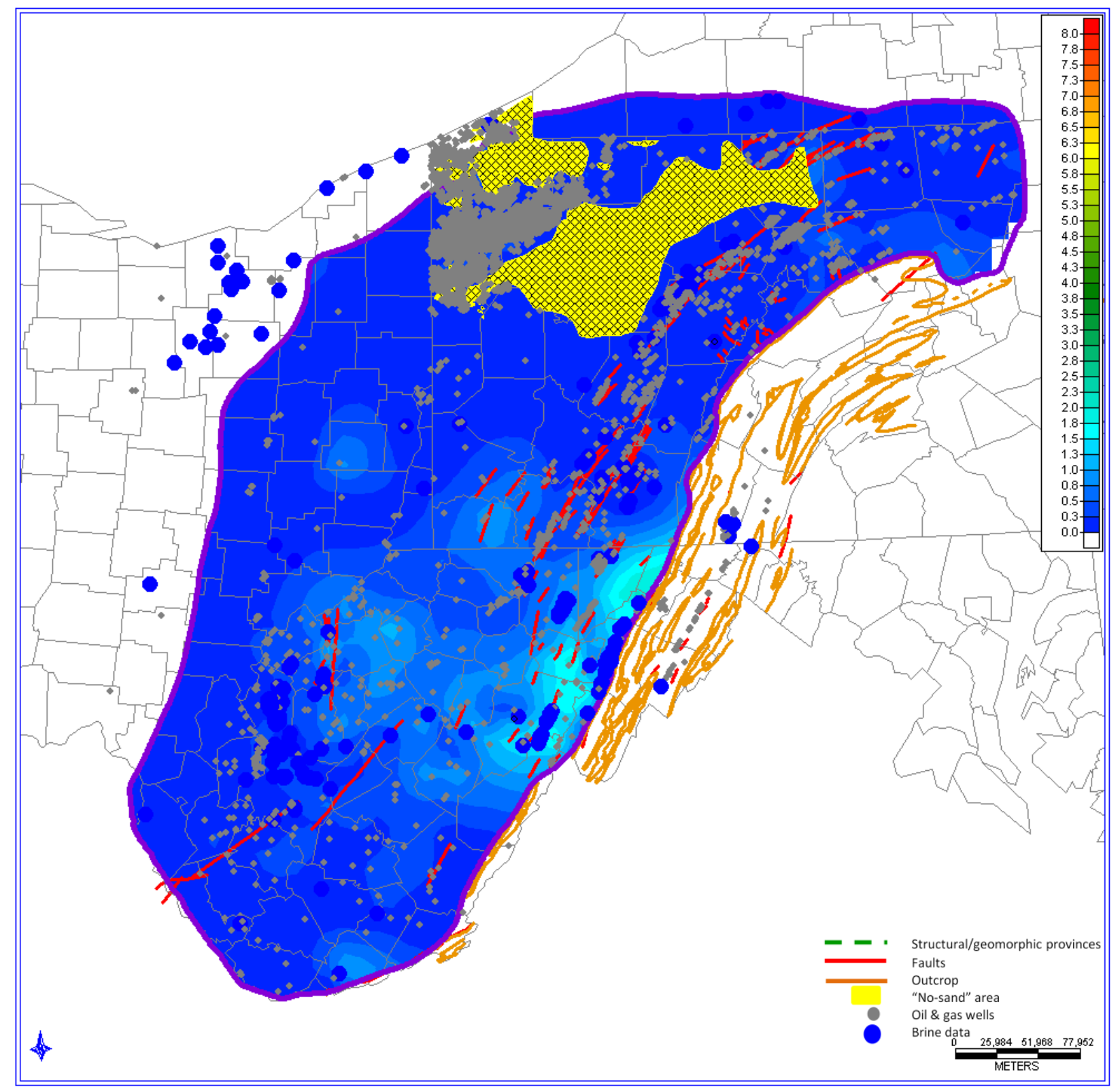

Figure 6-4. Oriskany Sandstone solubility storage capacity estimate using the Dilmore et al., (2008) method and the low storage efficiency factor of 0.01 . Contour interval is $0.25 \mathrm{~kg} / \mathrm{m}^{3}$. 


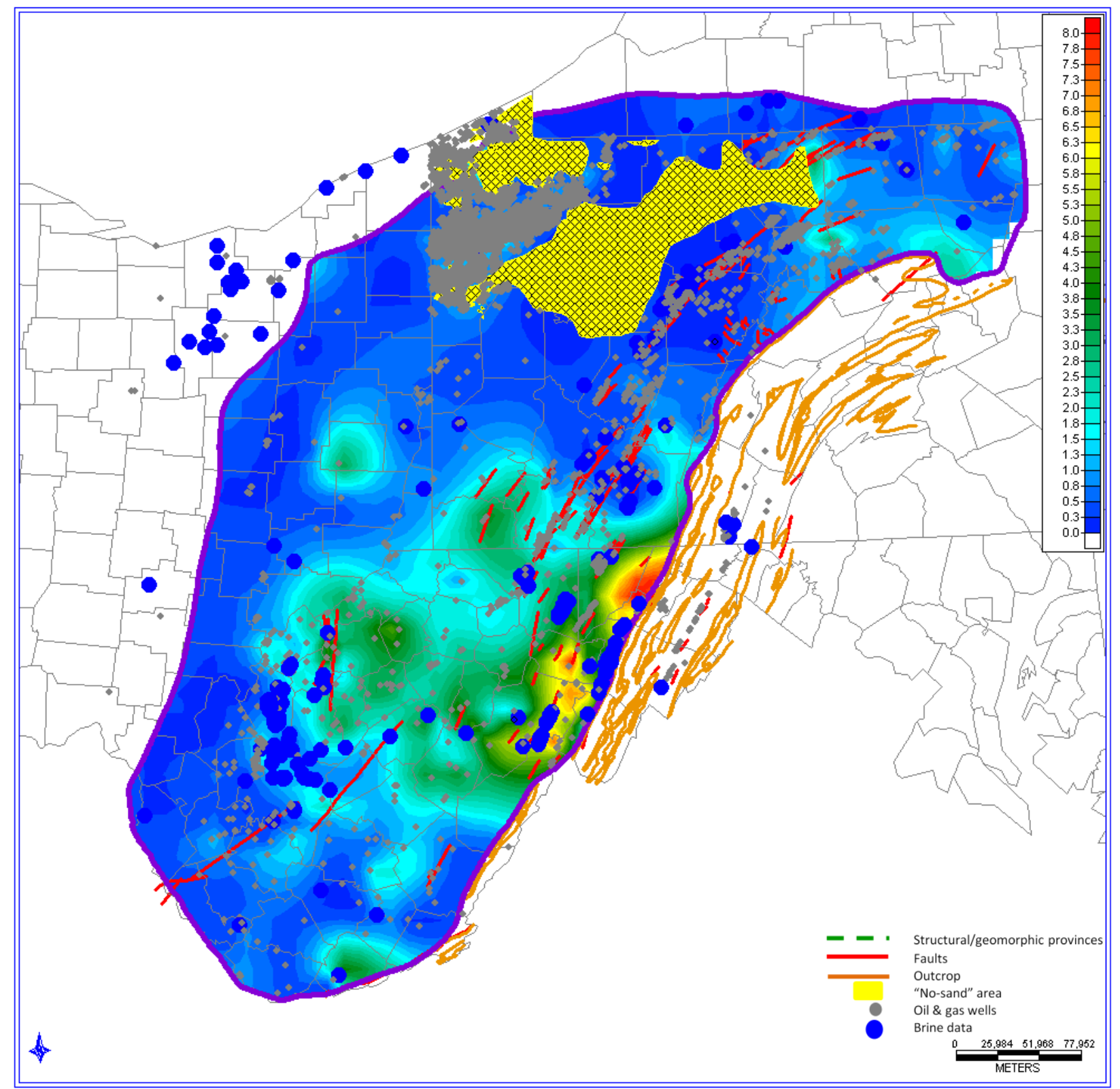

Figure 6-5. Oriskany Sandstone solubility storage capacity estimate using the Dilmore et al., (2008) method and the high storage efficiency factor of 0.04 . Contour interval is $0.25 \mathrm{~kg} / \mathrm{m}^{3}$. 


\section{CONCLUSIONS}

1. The geothermal gradient for the Appalachian basin, approximately $20^{\circ} \mathrm{C} / \mathrm{km}$, is lower than what is expected for cratonic rocks away from tectonic plate boundaries, 25$30^{\circ} \mathrm{C} / \mathrm{km}$, and would be considered a cold basin. In terms of $\mathrm{CO}_{2}$ sequestration, cold basins are better than warm basins because the depth that $\mathrm{CO}_{2}$ reaches supercritical conditions is shallower and therefore the $\mathrm{CO}_{2}$ is less buoyant which lowers the potential for and the relative speed of $\mathrm{CO}_{2}$ migration (Bachu, 2002). Hitchon, 1984, attributes low geothermal gradients to hydrodynamic flow.

2. The Oriskany of the Appalachian basin is generally underpressured with a pressure gradient of $6.8 \mathrm{kPa} / \mathrm{m}$ compared to a hydrostatic gradient of $9.74 \mathrm{kPa} / \mathrm{m}$ for freshwater and approximately $10.71 \mathrm{kPa} / \mathrm{m}$ for brine. This underpressuring would aid in sequestering $\mathrm{CO}_{2}$ by lowering injection and displacement pressures and is an indication of the integrity and longevity of the overlying confining layers and weak lateral migration, which will serve as a vertical seal. These seals have prevented the Oriskany from equalizing with the hydrostatic environment and could help prevent the vertical and lateral migration of $\mathrm{CO}_{2}$ (Puckette and Al-Shaieb, 2003).

3. The salinity of the Oriskany fluids varies widely across the Appalachian basin. The TDS ranges from freshwater (TDS $<10,000 \mathrm{mg} / \mathrm{L}$ ) to dense brine (TDS $>300,000 \mathrm{mg} / \mathrm{L}$ ). The relatively lower TDS concentrations are associated with the outcrop area to the east and indicate dilution by and mixing with fresh meteoric water. A high TDS concentration will decrease the solubility of $\mathrm{CO}_{2}$. Variations in brine geochemistry and physical parameters strongly affect residual, solubility, and mineral trapping. Injected 
$\mathrm{CO}_{2}$ is soluble in brine and forms carbonic acid, which dissociates into bicarbonate and carbonate ions thereby lowering the $\mathrm{pH}$. The Oriskany brine contains cations such as calcium, magnesium, and to a lesser extent iron, that can interact with the carbonate ions to form minerals such as calcite, dolomite, siderite and magnesite. The precipitation of these minerals occurs more favorably in a more basic pH (Soong et al., 2004). Reactions of $\mathrm{CO}_{2}$ charged saline fluids with minerals likely found in sandstone such as the Oriskany results in an increase in $\mathrm{pH}$ and therefore a greater capacity for the fluid to sequester dissolved $\mathrm{CO}_{2}$ (Allen et al., 2005).

4. Divergent flow patterns, based on hydraulic head estimates, are associated with the outcrop belt to the east and the area from the "no-sand area" southeast through the northern panhandle of West Virginia. These areas indicated also correspond to areas that historically have had low or no oil and gas production. Convergent flow patterns, based on hydraulic head estimates, are located within the High Plateau region, extending from New York toward the Allegheny Front. This area is associated with hydrocarbon production and has the potential for improved containment of injected $\mathrm{CO}_{2}$. 


\section{REFERENCES CITED}

Allen, D.E., Strazisar, B.R., Soong, Y., and Hedges, S.W., 2005, Modeling carbon dioxide sequestration in saline aquifers: Significance of elevated pressures and salinities: Fuel Processing Technology, v. 86, p. 15691580.

American Gas Association, 2001, Underground storage of natural gas in the United States and Canada: p. 80-86.

Anfont, S.J., Bachu, S., and Bentley, L.R., 2001, Regional-scale hydrogeology of the Upper Devonian-Lower Cretaceous sedimentary succession, south-central Alberta basin, Canada: The American Association of Petroleum Geologists, v. 85, p. 637-660.

Bachu, S., 1995a, Flow of variable-density formation water in deep sloping aquifers: review of methods of representation with case studies: Journal of Hydrology, v. 164, p. 19-38.

Bachu, S., 1995b, Synthesis and model of formation-water flow, Alberta basin, Canada: The American Association of Petroleum Geologists, v. 79, p. 1159-1178.

Bachu, S., 1997, Flow of formation waters, aquifer characteristics, and their relation to hydrocarbon accumulations, Northern Alberta Basin: The American Association of Petroleum Geologists, v. 81, p. 712-733.

Bachu, S., 2002, Sequestration of $\mathrm{CO}_{2}$ in geological media in response to climate change: road map for site selection using the transform of the geological space into the $\mathrm{CO}_{2}$ phase space: Energy Conversion \& Management, v. 43 , p. $87-102$.

Bachu, S., 2008, $\mathrm{CO}_{2}$ storage in geological media: role, means, status and barriers to development: Progress in Energy and Combustion Science, v. 34, p. 254-273.

Bachu, S., Bonijoly, D., Bradshaw, J., Burruss, R., Holloway, S., Christensen, N.P., and Mathiassen, O.D., 2007, $\mathrm{CO} 2$ storage capacity estimation: methodology and gaps: International Journal of Greenhouse Gas Control, v. 1, p. $430-433$. 
Bachu, S., Sauveplane, C.M., Lytviak, A.T., and Hitchon, B., 1987, Analysis of fluid and heat regimes in sedimentary basins: techniques for use with large data bases: The American Association of Petroleum Geologists, v. 71, p. 822-843.

Bachu, S., and Stewart, S., 2002, Geological sequestration of anthropogenic carbon dioxide in the Western Canada Sedimentary Basin: suitability analysis: Journal of Canadian Petroleum Technology, v. 41, p. 32-40.

Bachu, S., and Undershultz, J.R., 1992, Regional-scale porosity and permeability variations, Peace River Arch area, Alberta, Canada: The American Association of Petroleum Geologists, v. 76, p. 547-562.

Bachu, S., and Undershultz, J.R., 1993, Hydrogeology of formation waters, Northeastern Alberta basin: The American Association of Petroleum Geologists, v. 77, p. 1745-1768.

Bachu, S., and Undershultz, J.R., 1995, Large-scale underpressuring in the Mississippian-Cretaceous succession, Southwestern Alberta basin: The American Association of Petroleum Geologists, v. 79, p. 989-1004.

Benson, S.M., 2005, Overview of geologic storage of CO2, in Proceedings, International Conference on Greenhouse Gas Control Technologies, $7^{\text {th }}$, Vancouver, September 2004, Volume 1: Amsterdam: Elsevier, p. 665-672.

Birkholzer, J., and Tsang, C., 2007, Introduction to the special issue on site characterization for geological storage of $\mathrm{CO}_{2}$ : Environmental Geology, v. 54, p. 1579-1581.

Brennan, S.T., and Burruss, R.C., 2006, Specific storage volumes: a useful tool for CO2 storage capacity assessment: Natural Resources Research, v. 15, p. 165-181.

Bruner, K., and Smosna, D., 2008, A trip through the Paleozoic of the Central Appalachian basin with emphasis on the Oriskany Sandstone, Middle Devonian shales, and Tuscarora Sandstone: Dominion Exploration and Production, INC.

Carr, T.R., Merriam, D.F., and Bartley, J.D., 2005, Use of relational databases to evaluate regional petroleum accumulation, groundwater flow, and $\mathrm{CO} 2$ sequestration in Kansas: The American Association of Petroleum Geologists Bulletin, v. 89, p 1607-1627. 
Cook, P.J., and Benson, S.M., 2005, Overview and current issues in geological storage of carbon dioxide, in Proceedings, International Conference on Greenhouse Gas Control Technologies, $7^{\text {th }}$, Vancouver, September 2004, Volume 1: Amsterdam: Elsevier, p. 15-20.

CSLF, 2005: A taskforce for review and development of standards with regards to CO2 storage capacity measurement, CSLF-T-2005-09, p 1-25. http://www.cslforum.org/publications/documents/PhaseIReport StorageCapacityMeasurementTaskForce.pdf

Czernichowski-Lauriol, I., Rochelle, C., Gaus, I., Azaroul, M., Pearch, J., and Durst, P., 2006, Advances in the Geological Storage of Carbon Dioxide International Approaches to Reduce Anthropogenic Greenhouse Gas Emissions: Nato Science Series: IV: Earth and Environmental Sciences, 65. Springer E-Books. Dordrecht: Springer, p. 157-174.

Davies, P.B., 1987, Modeling areal, variable density, ground-water flow using equivalent head-analysis of potentially significant errors, in Proceedings, National Water Well Association-International Ground Water Modeling Center: Solving ground water problems with models, Denver, February 1987, Volume 1: Dublin, Ohio: National Water Well Association, p. 888-903.

Diecchio, R.J., 1985, Regional controls of gas accumulation in Oriskany sandstone, Central Appalachian basin: The American Association of Petroleum Geologists Bulletin, v. 69, p. 722-732.

Diecchio, R.J., Jones, S.E., and Dennison, J.M., 1984, Oriskany sandstone: regional stratigraphic relationships and production trends. Morgantown: West Virginia Geological and Economic Survey.

Dilmore, R.M., Allen, D.E., McCarthy Jones, J.R., Hedges, S.W., and Soong, Y., 2008, Sequestration of dissolved $\mathrm{CO}_{2}$ in the Oriskany Formation: Environmental Science and Technology, v. 42, p. 2760-2766.

Dresel, P.E., 1985, The geochemistry of oilfield brines in western Pennsylvania, thesis (M.S.), Pennsylvania State University. 
EIA (Energy Information Agency, US Department of Energy), 2009, Annual Energy Outlook 2009 with Projections to 2030, Report \#:DOE/EIA-0383(2009), p. 230. http://www.eia.doe.gov/oiaf/aeo/pdf/0383(2009).pdf (accessed November 9, 2009).

Forester, A., Merriam, D.F., and Watney, W.L., 1999, Problems and potential of industrial temperature data from a cratonic basin environment, in A. Forester and D.F. Merriam, eds., Geothermics in basin analysis: New York, Plenum Press, p. 35-59.

Frailey, S.M., Finley, R.J., and Hickman, T.S., 2006, CO2 sequestration;: storage capacity guideline needed: Oil \& Gas Journal, v. 104, p. 44-49.

Gill, A.E., 1982, Atmosphere-Ocean Dynamics: New York: Academic Press.

Gupta, N., Jagucki, P., Sminchak, J., Meggyesy, D., Spane, F., Ramakrishnan, T.S., and Boyd, A., Determining carbon sequestration injection potential at a site-specific location within the Ohio River Valley region, in Proceedings, International Conference on Greenhouse Gas Control Technologies, $7^{\text {th }}$, Vancouver, September 2004, Volume 1: Amsterdam: Elsevier, p. 511-519.

Harper, J.A., and Patchen, D.G., 1996, Play Dos: the Lower Devonian Oriskany Sandstone structural play, in Roen, J.B., and Walker, B.J., (Eds.), The atlas of major Appalachian gas plays: West Virginia Geological and Economic Survey Publication, v. 25, p. 109-117

Headlee, A.J.W., and Joseph, J.S., 1945, Permeability, porosity, and water content of natural gas reservoirs, Kanawha-Jackson and Campbells Creek Oriskany fields: West Virginia Geological and Economic Survey Publications, Bulletin No. 8, p. 16.

Heald, M.T., Thomson, A., and Wilcox, F.B., 1962, Origin of interstitial porosity in the Oriskany Sandstone of Kanawha County, West Virginia, Journal of Sedimentary Research, v. 32, p. 291-298.

Hitchon, B., 1984, Geothermal gradients, hydrodynamics, and hydrocarbon occurrences, Alberta, Canada: The American Association of Petroleum Geologists, v. 68, p. 713-743. 
Hitchon, B., 1996, Rapid evaluation of the hydrochemistry of a sedimentary basin using only 'standard' formation water analyses: example from the Canadian portion of the Williston Basin: Applied Geochemistry, v. 11, p. 789-795.

Hitchon, B., and Brulotte, M., 1994, Culling criteria for "standard” formation water analyses: Applied Geochemistry, v. 9, p. 637-645.

Hoskins, H.A., 1947, Analysis of West Virginia Brines: West Virginia Geologic and Economic Survey Publication, Reports of Investigation RI-1, p. 22.

IPCC-Intergovernmental Panel on Climate Change, 1995, Climate change 1995: The science of climate change: Houghton, J.T., Meira Filho, L.G., Collander, B.A., Harris, N., Kattenberg, A., Maskell, K., (Eds.): Cambridge University Press: Cambridge, U.K., 1996.

IPCC-Intergovernmental Panel on Climate Change, 2005, Special report on carbon dioxide capture and storage: Metz, B., Davidson, O., de Coninck, H.C., Loos, M., Meyer, L.A., (Eds.), Cambridge University Press, Cambridge, UK and New York, chapter 5, p. 195-276.

Jorgensen, D.G., Helgesen, J.O., and Imes, J.L., 1993, Regional aquifers in Kansas, Nebraska, and parts of Arkansas, Colorado, Missouri, New Mexico, Oklahoma, South Dakota, Texas, and Wyoming; geohydrologic framework: U.S. Geological Survey Professional Paper, Report: p 1414-B, p. 72.

Kelley, D., DeBor, D., Malanchak, J., and Anderson, D., 1973, Tully and deeper formations, brine analysis of Pennsylvania: Pennsylvania Geological Survey, $4^{\text {th }}$ ser., Open-file Report OF 73-03.

Lloyd, O.B., and Reid, M.S., 1990, Evaluation of liquid waste-storage potential based on porosity distribution in the Paleozoic rocks in central and southern parts of the Appalachian Basin: U.S. Geological Survey professional paper: $\mathrm{p} 81$.

Martini, A.M., Walter, L.M., Budai, J.M., Ku, T.C.W., Kaiser, C.J., and Schoell, M., 1998, Genetic and temporal relations between formation waters and biogenic methane: Upper Devonian Antrim Shale, Michigan Basin, USA: Geochimica et Cosmochimica Acta, v. 62, p. 1699-1720. 
McIntosh, J.C., and Martini, A.M., 2005, Hydrogeochemical indicators for microbial methane in fractured organicrich Shales: Case study of the Antrim, New Albany, and Ohio shales, in Bishop, M.G., (eds.), Gas in low permeability reservoirs of the Rocky Mountain Region: Rocky Mountain Association of Geologists Publication, p. 1-13.

McIntosh, J.C., Walter, L.M., and Martini, A.M., 2002, Pleistocene recharge to midcontinent basins: effects on salinity structure and microbial gas generation; Geochimica et Cosmochimica Acta, v. 66, p. 1681-1700.

O’Dell, J.W., Pfaff, J.D., and Budde, W.L., 1993, Methods for the determination of inorganic substances in environmental samples: Environmental Monitoring Systems Laboratory, Office of Research and Development, U.S. Environmental Protection Agency, EPA Method 300: http://www.epa.gov/nerlcwww/methmans.html\#Inorg.\%20Non-metals (accessed August 24, 2008).

Opritza, S.T., 1996, Play Dop: the Lower Devonian Oriskany Sandstone updip permeability pinchout, in Roen, J.B., and Walker, B.J., (eds.), The atlas of major Appalachian gas plays: West Virginia Geological and Economic Survey Publication, v. 25, p. 126-129.

Patchen, D.G., and Harper, J.A., 1996, Play Doc: the Lower Devonian Oriskany Sandstone combination traps play, in Roen, J.B., and Walker, B.J., (Eds.), The atlas of major Appalachian gas plays: West Virginia Geological and Economic Survey Publication, v. 25, p. 118-125.

Pennsylvania Geological Survey, Subsurface rock correlation chart, Oriskany Sandstone, http://www.denr.state.pa.us/topogeo/drc/tabledev.aspx (accessed August 24, 2008).

Poth, C.W., 1962, The occurrence of brine in western Pennsylvania: Department of Internal Affairs, Harrisburg, Bulletin M 47, p. 53.

Price, P.H., Hare, C.E., McCue, J.B., and Hoskins, H.A., 1937, Salt brines of West Virginia: West Virginia Geological and Economic Survey Publication, v. 8, p. 203. 
Puckette, J., and Al-Shaieb, 2003, Naturally underpressured reservoirs: applying the compartment concept to the safe disposal of liquid waste: The American Association of Petroleum Geologists, AAPG Southwest Section Meeting, Fort Worth, TX, March 2003.

Radtke, D.B., Davis, J.V., and Wilde, F.D., Rounds, S.A., August 2005, Specific Electrical Conductance (version 1.2): U.S. Geological Survey Techniques of Water-Resources Investigations, book 9, chap. A6, section 6.3: http://pubs.water.usgs.gov/twri9A6/ (accessed August 16, 2008).

Russell, W.L., 1972, Pressure-depth relations in Appalachian region: The American Association of Petroleum Geologists, v. 56, p. 528-536.

Soong, Y., Allen, D.E., McCarthy-Jones, J.R., Harrison, D.K., Hedges, S.H., Baltrus, J.P., and Zhu, C., 2004a, Preliminary experimental results of $\mathrm{CO}_{2}$ sequestration with brine: in Proceedings of the Eleventh International Symposium on Water-Rock Interaction, Saratoga Springs: New York, p. 597-600.

Soong, Y., Goodman, A.L., McCarthy-Jones, J.R., and Baltrus, J.P., 2004b, Experimental and simulation studies on mineral trapping of $\mathrm{CO}_{2}$ with brine: Energy Conversion and Management, v. 45, p. 1845-1859.

Stout, W., Lamborn, R.E., and Schaaf, D., 1932, Brines of Ohio (A preliminary report): Geological Society of Ohio, Fourth Series, Bulletin 37.

Swartz, C.K., 1913, The Lower Devonian deposits of Maryland: Correlation of the Lower Devonian: Maryland Geological Survey, Lower Devonian, p. 96-123.

Tans, P., 2008, Trends in atmospheric carbon dioxide-Mauna Loa: United States Department of Commerce: http://www.esrl.noaa.gov/gmd/ccgg/trends/ (accessed November 09, 2009).

USDOE, 1999, Carbon Sequestration Research and Development: United States Department of Energy, Office of Science, Office of Fossil Energy, December 1999: www.fossil.energy.gov/programs/sequestration/publications/1999_rdreport/front_feb.pdf (accessed July 11, 2008). 
USDOE, 2007, Carbon Sequestration Atlas of the United States and Canada: United States Department of Energy, Office of Fossil Energy National Energy Technology Laboratory Report, March 2007: http://www.netl.doe.gov/technologies/carbon_seq/refshelf/atlas/ATLAS.pdf (accessed April 24, 2008).

USDOE, 2008, Methodology for development of geologic storage estimates for carbon dioxide: United States Department of Energy, National Energy Technology Laboratory, Carbon Sequestration Program, August 2008:

http://fossil.energy.gov/programs/sequestration/publications/Project_Reports/carbonstorage_method08.pdf (accessed October 30, 2008).

U.S. Geological Survey, September 2006, Collection of water samples (ver. 2.0): U.S. Geological Survey Techniques of Water-Resources Investigations, book 9, chap. A4: http://pubs.water.usgs.gov/twri9A4/ (accessed August 16, 2008).

UTBEG, Bureau of Economic Geology, the University of Texas at Austin, Research Environmental Quality, http://www.beg.utexas.edu/environqlty/co2seq/research.htm, (accessed August 25, 2008).

Vanuxem, L., 1839, Third annual report of the Geological Survey of the third district: New York Geological Survey, Annual Report 1839, p. 273.

Wickstrom, L. H., Venteris, E.R., Harper, J.A., McDonald, J., Slucher, E.R., Carter, K.M., Greb, S.F., Wells, J.G., Harrison, W.B., Nuttall, B.C., Riley, R.A., Drahovzal, J.A., Rupp, J.A., Avary, K.L., Lanham, S., Barnes, D.A., Gupta, N., baranoski, M.A., Radhakkrishnan, P., Solis, M.P., Baum, G.R., Powers, D., Hohn, M.E., Parris, M.P., McCoy, K., Grammer, G.M., Pool, S., Luckhardt, C., and Kish, P., 2005, Characterization of geologic sequestration opportunities in the MRCSP region: Phase I task report, October 2003-September 2005: DOE No. DE-PS26-05NT42255, p. 152.

Wilde, F.D., Busenburg, E., and Radtke, D.B., January 2006, pH (version 1.3): U.S. Geological Survey Techniques of Water-Resources Investigations, book 9, chap. A6, section 6.4: http://pubs.water.usgs.gov/twri9A6/ (accessed August 16, 2008). 
Woll, R.S., 1978, Maryland ground-water information: chemical quality data: Maryland Geological Survey Publication: Water Resources Basic-Data Report No. 10, p. 102. 


\section{Tables}

Table 1. Oriskany Sandstone porosity data.

\begin{tabular}{|c|c|c|c|}
\hline State & County/Area & Field Name & Average Core Porosity (\%) \\
\hline New York & Southwestern Counties & N/A & 9.0 \\
\hline \multirow[t]{15}{*}{ Pennsylvania } & Beaver & & 5.2 \\
\hline & Bedford & & $4.0-8.0$ \\
\hline & Clinton & Leidy & $8.09-8.58$ \\
\hline & Elk & & 1.7 \\
\hline & Erie & Erie & 8.6 \\
\hline & Potter & Leidy & 8.3 \\
\hline & Somerset & Winding/Boardman & $6.0-7.0$ \\
\hline & Somerset & Engleka/Hemminger & $0.14-0.20$ \\
\hline & Somerset & West Ashtola & $0.32-0.35$ \\
\hline & Somerset & North Jerome & $0.87-1.04$ \\
\hline & Somerset & Coxes Creek & 0.72 \\
\hline & Somerset & Lavansville & $0.29-0.78$ \\
\hline & Greene & Shamrock & 1.17 \\
\hline & Indiana & Buffington/Pine & 6.2 \\
\hline & Lawrence & Mt. Jackson & $8.0-21.0$ \\
\hline \multirow[t]{8}{*}{ West Virginia } & Tucker & Canaan Valley & 7.0 \\
\hline & Kanawha & Elk-Poca & 8 \\
\hline & Jackson & Elk-Poca & 8 \\
\hline & Jackson & Rockport & 17 \\
\hline & Putnam & Elk-Poca & 8 \\
\hline & Randolph & Randolph/Tucker & 9 \\
\hline & Tucker & Randolph/Tucker & 9 \\
\hline & Wood & Rockport & 17 \\
\hline
\end{tabular}


Table 2. Criteria for culling formation water analyses based on chemical analysis (Hitchon and Brulotte, 1994).

\begin{tabular}{|l|l|}
\hline \multicolumn{1}{|c|}{ Criteria for Rejection } & \multicolumn{1}{c|}{ Possible Causes } \\
\hline $\begin{array}{l}\text { Any } \mathrm{Ca}, \mathrm{Mg}, \mathrm{Cl}, \text { or }_{4} \mathrm{SO}_{4} \\
\text { with missing or zero values }\end{array}$ & $\begin{array}{l}\text { Incomplete analysis; insufficient sample; very low content, thus difficultly in } \\
\text { determination }\end{array}$ \\
\hline $\mathrm{Mg} \geq \mathrm{Ca}$ & $\begin{array}{l}\text { Signifies loss of } \mathrm{CO}^{2} \text { and precipitation of } \mathrm{CaCO}^{3} \text { before analysis; very low } \mathrm{Ca}+\mathrm{Mg}, \\
\text { thus difficulty in determination; incorrect entry of } \mathrm{Ca}+\mathrm{Mg} \text { as equivalent } \mathrm{Ca} \text { as } \\
\text { separate Ca and } \mathrm{Mg} \text { values }\end{array}$ \\
\hline $\mathrm{OH}$ reported & Wash from cement job; poor analysis \\
\hline $\mathrm{CO} 3$ reported & Contamination from drilling mud; poor sampling of separator or treater \\
\hline $\mathrm{Na}$ (calculated) is negative & Poor analysis \\
\hline Density $<1.0$ & Poor determination; organic matter contamination \\
\hline
\end{tabular}


Table 3. Polynomial fit correlating formation temperature to density of $\mathrm{CO} 2$-saturated brine. This polynomial correlates temperature, pressure, and depth to the Oriskany model brine of Dilmore et al. (2008).

$$
\delta=a_{0}+a_{1} T+a_{2} T^{2}+a_{3} T^{3}+a_{4} T^{4}
$$

$\mathrm{R}_{2}=0.9996$

\begin{tabular}{|lcc|}
\hline & Value & $95 \%$ confidence \\
\hline $\mathrm{a}_{0}$ & 1.13261 & 0.009947 \\
$\mathrm{a}_{1}$ & 0.0012873 & 0.0001723 \\
$\mathrm{a}_{2}$ & $-3.46 \mathrm{E}-05$ & $5.048 \mathrm{E}-06$ \\
$\mathrm{a}_{3}$ & $3.144 \mathrm{E}-07$ & $6.058 \mathrm{E}-08$ \\
$\mathrm{a}_{4}$ & $-1.161 \mathrm{E}-09$ & $2.55 \mathrm{E}-10$ \\
\hline
\end{tabular}


Table 4. Polynomial fit correlating temperature to formation $\mathrm{CO} 2$ concentration. This polynomial correlates temperature, pressure, and depth to Oriskany $\mathrm{CO} 2$ concentration (Dilmore et al., 2008).

$$
m C O_{2}=a_{0}+a_{1} T+a_{2} T^{2}+a_{3} T^{3}+a_{4} T^{4}+a_{5} T^{5}+a_{6} T^{6}+a_{7} T^{7}+a_{8} T^{8}
$$

$\mathrm{R}_{2}=09991$

\begin{tabular}{|ccc|}
\hline & Value & $95 \%$ confidence \\
\hline $\mathrm{a}_{0}$ & -4.874733 & 1.094567 \\
$\mathrm{a}_{1}$ & 0.5667273 & 0.2017776 \\
$\mathrm{a}_{2}$ & -0.0223232 & 0.015391 \\
$\mathrm{a}_{3}$ & 0.0003551 & 0.0006366 \\
$\mathrm{a}_{4}$ & $6.069 \mathrm{E}-07$ & $1.568 \mathrm{E}-05$ \\
$\mathrm{a}_{5}$ & $-1.045 \mathrm{E}-07$ & $2.364 \mathrm{E}-07$ \\
$\mathrm{a}_{6}$ & $1.537 \mathrm{E}-09$ & $2.14 \mathrm{E}-09$ \\
$\mathrm{a}_{7}$ & $-9.701 \mathrm{E}-12$ & $1.068 \mathrm{E}-11$ \\
$\mathrm{a}_{8}$ & $2.346 \mathrm{E}-14$ & $2.254 \mathrm{E}-14$ \\
\hline
\end{tabular}


Appendix I

Oriskany Sandstone Formation Temperature Data 
Oriskany Sandstone formation temperature data.

\begin{tabular}{|c|c|c|c|c|c|c|c|}
\hline API Number & Source & Formation & Latitude & Longitude & GL Elevation (m) & Depth to Top of Formation (m) & Temperature $\left({ }^{\circ} \mathrm{C}\right)$ \\
\hline 3109713796 & $\mathrm{C}$ & Oriskany & & & 423 & 741 & 24.4 \\
\hline 3100723083 & C & Oriskany & & & 433 & 741 & 24.0 \\
\hline 3110112960 & $\mathrm{C}$ & Oriskany & & & 404 & 911 & 27.8 \\
\hline 3102322818 & C & Oriskany & & & 509 & 822 & 27.8 \\
\hline 3700920061 & C & Oriskany & & & 396 & 1289 & 28.3 \\
\hline 3110112923 & $\mathrm{C}$ & Oriskany & & & 552 & 1110 & 30.0 \\
\hline 3100313684 & $\mathrm{C}$ & Oriskany & & & 555 & 960 & 32.8 \\
\hline 3110112972 & C & Oriskany & & & 587 & 1271 & 35.6 \\
\hline 3100311762 & C & Oriskany & & & 612 & 1361 & 36.3 \\
\hline 3110110036 & C & Oriskany & & & 616 & 1403 & 36.7 \\
\hline Chesapeake-1 & C & Oriskany & & & 878 & 2821 & 36.0 \\
\hline 3408100651 & $\mathrm{C}$ & Oriskany & & & 360 & 1517 & 40.6 \\
\hline 4707500020 & $\mathrm{C}$ & Oriskany & 38.60889 & -79.64920 & 1088 & 1783 & 42.2 \\
\hline 3110113578 & $\mathrm{C}$ & Oriskany & & & 699 & 1497 & 43.3 \\
\hline 3700900024 & $C$ & Oriskany & & & 359 & 1611 & 43.3 \\
\hline 3100915731 & $\mathrm{C}$ & Oriskany & & & 529 & 1234 & 45.0 \\
\hline 3711702007 & $\mathrm{C}$ & Oriskany & & & 489 & 1566 & 45.0 \\
\hline 4707500023 & C & Oriskany & 38.53760 & -79.67849 & 1027 & 1573 & 46.1 \\
\hline 4703901018 & $\mathrm{C}$ & Helderberg & 38.25858 & -81.63494 & 244 & 1599 & 46.1 \\
\hline Chesapeake-2 & $\mathrm{C}$ & Oriskany & & & 740 & 1740 & 46.7 \\
\hline 3700920059 & $\mathrm{C}$ & Oriskany & & & 470 & 1975 & 48.3 \\
\hline 3408100412 & $\mathrm{C}$ & Oriskany & & & 360 & 1748 & 48.9 \\
\hline 4707500050 & $\mathrm{C}$ & Oriskany & 38.61832 & -79.64532 & 1145 & 1872 & 50.0 \\
\hline Chesapeake-3 & $\mathrm{C}$ & Oriskany & & & 731 & 1869 & 50.0 \\
\hline 4709702415 & $\mathrm{C}$ & Oriskany & 38.83397 & -80.32758 & 371 & 2431 & 55.0 \\
\hline 4706101316 & C & Huntersville & 39.57071 & -79.85469 & 474 & 2373 & 55.6 \\
\hline 3706300694 & C & Huntersville & & & 471 & 2390 & 58.9 \\
\hline 3705120506 & C & Huntersville & & & 765 & 2363 & 59.4 \\
\hline 4702300012 & C & Oriskany & 39.08072 & -79.26823 & 815 & 2632 & 60.6 \\
\hline 4702300021 & $\mathrm{C}$ & Oriskany & 39.07782 & -79.25428 & 611 & 2643 & 60.6 \\
\hline
\end{tabular}




\begin{tabular}{|c|c|c|c|c|c|c|c|}
\hline API Number & Source & Formation & Latitude & Longitude & GL Elevation (m) & Depth to Top of Formation (m) & Temperature $\left({ }^{\circ} \mathrm{C}\right)$ \\
\hline 4707700316 & $\mathrm{C}$ & Oriskany & 39.53456 & -79.85094 & 566 & 2412 & 62.8 \\
\hline 4705700022 & $\mathrm{C}$ & Oriskany & 39.40201 & -79.40201 & 585 & 2624 & 62.8 \\
\hline 4709703017 & $\mathrm{C}$ & Oriskany & 38.86339 & -80.28058 & 532 & 2333 & 62.8 \\
\hline 4705700037 & $\mathrm{C}$ & Oriskany & 39.35977 & -79.06115 & 393 & 3020 & 64.4 \\
\hline 4707700126 & C & Oriskany & 39.50392 & -79.87606 & 585 & 2372 & 65.6 \\
\hline 4707100010 & C & Helderberg & 38.91014 & -79.34745 & 769 & 2758 & 65.6 \\
\hline 4708300904 & $C$ & Oriskany & 38.62224 & -79.88941 & 1131 & 2612 & 65.6 \\
\hline 4707100013 & $C$ & Helderberg & 38.74623 & -79.46240 & 877 & 2498 & 67.8 \\
\hline 4706101313 & $C$ & Huntersville & 39.57869 & -79.90216 & 476 & 2336 & 67.8 \\
\hline 3706300083 & $\mathrm{C}$ & Oriskany & & & 434 & 2282 & 67.8 \\
\hline 3705120245 & $\mathrm{C}$ & Oriskany & & & 861 & 2625 & 68.3 \\
\hline 4706101314 & $\mathrm{C}$ & Oriskany & 39.48041 & -79.90567 & 565 & 2373 & 68.9 \\
\hline 4706101311 & $\mathrm{C}$ & Oriskany & 39.60723 & -79.85506 & 603 & 2432 & 68.9 \\
\hline 4705700016 & C & Helderberg & 39.41304 & -79.03553 & 570 & 2665 & 68.9 \\
\hline 4702300026 & $\mathrm{C}$ & Helderberg & 39.20456 & -79.20871 & 882 & 3016 & 70.0 \\
\hline 3705120507 & $\mathrm{C}$ & Oriskany & & & 831 & 2708 & 70.0 \\
\hline 4707100012 & C & Helderberg & 38.79632 & -79.42260 & 824 & 2606 & 71.1 \\
\hline 4707700345 & $\mathrm{C}$ & Helderberg & 39.62094 & -79.67229 & 0 & 2474 & 72.2 \\
\hline 3706300382 & $\mathrm{C}$ & Oriskany & & & 469 & 2344 & 73.3 \\
\hline 3711100019 & C & Oriskany & & & 740 & 2589 & 74.4 \\
\hline 4705700059 & $\mathrm{C}$ & Helderberg & 39.45472 & -79.04226 & 722 & 3182 & 76.7 \\
\hline 4707100014 & $C$ & Helderberg & 38.85570 & -79.39910 & 856 & 2798 & 78.3 \\
\hline Chesapeake-4 & $\mathrm{C}$ & Oriskany & & & 411 & 2138 & 73.0 \\
\hline
\end{tabular}

Source: $\quad$ C-Chesapeake Energy

All data used in this study are available on the West Virginia GIS Technical Center website http://wvgis.wvu.edu. 
Appendix II

Oriskany Sandstone Formation Pressure Data 
Oriskany Sandstone formation pressure data

\begin{tabular}{|c|c|c|c|c|c|c|c|}
\hline API Number & Source & Formation & Latitude & Longitude & GL Elevation (m) & Depth to Top Oriskany (m) & Pressure $(\mathrm{kPa})$ \\
\hline 3400720085 & $A$ & Oriskany & 41.74362 & -80.55750 & 305 & 719 & 6571 \\
\hline 3400720097 & A & Oriskany & 41.74252 & -80.57179 & 305 & 718 & 6447 \\
\hline 3409320696 & A & Oriskany & 41.34812 & -82.02845 & 234 & 394 & 3241 \\
\hline 3410320357 & A & Oriskany & 41.20962 & -81.69461 & 289 & 580 & 5137 \\
\hline 3410320396 & A & Oriskany & 41.21446 & -81.69365 & 374 & 648 & 4895 \\
\hline 3410320399 & A & Oriskany & 41.21684 & -81.69517 & 376 & 662 & 7412 \\
\hline 3410320405 & A & Oriskany & 41.21468 & -81.68951 & 334 & 617 & 7584 \\
\hline 3410320571 & A & Oriskany & 41.20426 & -81.70448 & 298 & 593 & 7929 \\
\hline 3410320591 & $A$ & Oriskany & 41.20837 & -81.70214 & 297 & 622 & 6929 \\
\hline 3410521463 & A & Oriskany & 38.93080 & -81.79015 & 178 & 1290 & 9791 \\
\hline 3413320341 & $A$ & Oriskany & 41.04369 & -81.20816 & 369 & 925 & 7446 \\
\hline 3415320249 & $A$ & Oriskany & 41.21769 & -81.63165 & 361 & 644 & 4137 \\
\hline 3415320255 & A & Oriskany & 41.21742 & -81.63381 & 363 & 659 & 4675 \\
\hline 3415320256 & A & Oriskany & 41.21965 & -81.63129 & 358 & 642 & 4482 \\
\hline 3415320260 & $A$ & Oriskany & 41.22003 & -81.63468 & 367 & 662 & 4137 \\
\hline 3415320265 & A & Oriskany & 41.21837 & -81.63459 & 366 & 663 & 4661 \\
\hline 3415320268 & A & Oriskany & 41.22252 & -81.63418 & 360 & 654 & 3654 \\
\hline 3415320272 & A & Oriskany & 41.21872 & -81.63567 & 382 & 666 & 2930 \\
\hline 3415320275 & A & Oriskany & 41.22036 & -81.63566 & 370 & 664 & 2689 \\
\hline 3415320276 & $A$ & Oriskany & 41.21855 & -81.63773 & 383 & 664 & 2758 \\
\hline 3415320302 & A & Oriskany & 41.22728 & -81.63253 & 351 & 643 & 4206 \\
\hline 4700100619 & B & Oriskany & 39.06838 & -80.02232 & 626 & 2432 & 6895 \\
\hline 4700101504 & $\mathrm{~B}$ & Oriskany & 39.04357 & -80.00167 & 637 & 2410 & 18961 \\
\hline 4700500602 & B & Oriskany & 38.19251 & -81.64889 & 321 & 1421 & 6412 \\
\hline 4700500900 & B & Oriskany & 37.97344 & -81.95055 & 351 & 1315 & 3034 \\
\hline 4700501056 & B & Oriskany & 37.96331 & -81.79329 & 326 & 1601 & 3689 \\
\hline
\end{tabular}




\begin{tabular}{|c|c|c|c|c|c|c|c|}
\hline API Number & Source & Formation & Latitude & Longitude & GL Elevation (m) & Depth to Top Oriskany (m) & Pressure (kPa) \\
\hline 4700702305 & B & Oriskany & 38.75408 & -80.63760 & 336 & 2160 & 9653 \\
\hline 4701501915 & B & Oriskany & 38.57948 & -81.01992 & 267 & 1870 & 4426 \\
\hline 4701702556 & B & Oriskany & 39.33029 & -80.77613 & 243 & 2100 & 14824 \\
\hline 4702103376 & B & Oriskany & 38.96374 & -80.81037 & 287 & 2052 & 16892 \\
\hline 4702104270 & B & Oriskany & 38.94324 & -80.82175 & 265 & 1985 & 9997 \\
\hline 4702104374 & B & Oriskany & 38.91667 & -80.98674 & 238 & 1883 & 12928 \\
\hline 4702104886 & B & Oriskany & 38.96807 & -80.89654 & 220 & 1899 & 16616 \\
\hline 4702104892 & $B$ & Oriskany & 38.97533 & -80.84726 & 241 & 1940 & 10411 \\
\hline 4702105055 & B & Oriskany & 38.97170 & -80.82360 & 346 & 2044 & 11549 \\
\hline 4702105355 & $B$ & Oriskany & 39.03789 & -80.81083 & 350 & 2115 & 10515 \\
\hline 4702300007 & C & Oriskany & 39.95471 & -79.32992 & 825 & 2563 & 20684 \\
\hline 4702300008 & C & Oriskany & 39.12748 & -79.24653 & 796 & 2448 & 22063 \\
\hline 4702300009 & C & Oriskany & 39.96604 & -79.32082 & 834 & 2508 & 17554 \\
\hline 4702300013 & C & Oriskany & 39.09597 & -79.27809 & 904 & 2650 & 20133 \\
\hline 4702300015 & $\mathrm{C}$ & Oriskany & 39.05692 & -79.27511 & 765 & 2423 & 17554 \\
\hline 4702300017 & C & Oriskany & 39.02178 & -79.29464 & 868 & 2582 & 19650 \\
\hline 4702300022 & $B$ & Oriskany & 39.16420 & -79.22622 & 818 & 2576 & 13169 \\
\hline 4702300023 & $\mathrm{~V}$ & Oriskany & 39.10715 & -79.26953 & 829 & 2557 & 14548 \\
\hline 4702300024 & $\mathrm{~B}$ & Oriskany & 39.06998 & -79.27604 & 841 & 2586 & 8963 \\
\hline 4702300030 & V & Oriskany & 39.28557 & -79.15300 & 814 & 2833 & 23856 \\
\hline 4702300033 & $\mathrm{~B}$ & Oriskany & 39.10337 & -79.26153 & 665 & 2381 & 9997 \\
\hline 4702700003 & $\mathrm{~B}$ & Oriskany & 39.31606 & -78.63784 & 409 & 1708 & 14479 \\
\hline 4702700004 & $B$ & Oriskany & 39.30024 & -78.65259 & 367 & 1465 & 14134 \\
\hline 4702700008 & $\mathrm{~B}$ & Oriskany & 39.30997 & -78.64493 & 390 & 1609 & 13652 \\
\hline 4702700009 & $B$ & Oriskany & 39.29400 & -78.65203 & 381 & 1551 & 13927 \\
\hline 4702700010 & $B$ & Oriskany & 39.29487 & -78.64829 & 363 & 1695 & 12755 \\
\hline 4702700013 & $\mathrm{~B}$ & Oriskany & 39.44803 & -78.54971 & 277 & 1569 & 11170 \\
\hline 4702700015 & B & Oriskany & 39.38111 & -78.59530 & 300 & 1630 & 13748 \\
\hline
\end{tabular}




\begin{tabular}{|c|c|c|c|c|c|c|c|}
\hline API Number & Source & Formation & Latitude & Longitude & GL Elevation (m) & Depth to Top Oriskany (m) & Pressure (kPa) \\
\hline 4702700016 & B & Oriskany & 39.35992 & -78.60877 & 348 & 1743 & 13431 \\
\hline 4702700017 & B & Oriskany & 39.35034 & -78.62691 & 342 & 1598 & 13790 \\
\hline 4702700019 & B & Oriskany & 39.44862 & -78.54133 & 207 & 1636 & 5171 \\
\hline 4702700021 & B & Oriskany & 39.36964 & -78.60054 & 328 & 1665 & 13128 \\
\hline 4702700022 & B & Oriskany & 39.16828 & -78.77106 & 535 & 1970 & 15169 \\
\hline 4702700024 & B & Oriskany & 39.18540 & -78.75317 & 576 & 1942 & 15031 \\
\hline 4702700025 & B & Oriskany & 39.25859 & -78.68384 & 438 & 1570 & 13548 \\
\hline 4702700026 & $\mathrm{~B}$ & Oriskany & 39.24536 & -78.69257 & 477 & 1758 & 8274 \\
\hline 4702700029 & B & Oriskany & 39.36717 & -78.60596 & 324 & 1689 & 11135 \\
\hline 4702700030 & $\mathrm{~B}$ & Oriskany & 39.37777 & -78.59867 & 310 & 1664 & 12411 \\
\hline 4702900120 & $\mathrm{~B}$ & Oriskany & 40.58029 & -80.62135 & 306 & 1422 & 10342 \\
\hline 4703100005 & B & Oriskany & 38.99129 & -78.85617 & 631 & 2128 & 15720 \\
\hline 4703100006 & $\mathrm{~B}$ & Oriskany & 39.00321 & -78.83798 & 569 & 2084 & 15927 \\
\hline 4703100008 & $\mathrm{~B}$ & Oriskany & 38.97794 & -78.86936 & 515 & 2022 & 15927 \\
\hline 4703100009 & B & Oriskany & 39.01353 & -78.84140 & 626 & 2060 & 15927 \\
\hline 4703100010 & $\mathrm{~B}$ & Oriskany & 39.02573 & -78.83439 & 635 & 2094 & 15927 \\
\hline 4703100012 & $\mathrm{~B}$ & Oriskany & 39.03441 & -78.82273 & 561 & 1906 & 15927 \\
\hline 4703100016 & $\mathrm{~B}$ & Oriskany & 38.93801 & -78.90081 & 674 & 2025 & 13452 \\
\hline 4703100017 & $\mathrm{~B}$ & Oriskany & 39.05314 & -78.81101 & 500 & 2008 & 9929 \\
\hline 4703100018 & $\mathrm{~B}$ & Oriskany & 39.15433 & -78.78466 & 544 & 2100 & 15479 \\
\hline 4703100019 & $\mathrm{~B}$ & Oriskany & 39.14054 & -78.79465 & 571 & 1953 & 14817 \\
\hline 4703304176 & $\mathrm{~B}$ & Oriskany & 39.43714 & -80.35727 & 337 & 2279 & 7240 \\
\hline 4703500038 & $B$ & Oriskany & 38.59916 & -81.64576 & 224 & 1529 & 12893 \\
\hline 4703500040 & $\mathrm{~B}$ & Oriskany & 38.59679 & -81.64258 & 271 & 1570 & 12411 \\
\hline 4703500043 & $\mathrm{~B}$ & Oriskany & 38.96845 & -81.64775 & 201 & 1434 & 13100 \\
\hline 4703500045 & $B$ & Oriskany & 38.59794 & -81.63216 & 279 & 1593 & 12411 \\
\hline 4703500051 & $\mathrm{~B}$ & Oriskany & 38.59050 & -81.60731 & 238 & 1549 & 12617 \\
\hline 4703500061 & B & Oriskany & 38.59373 & -81.58377 & 212 & 1527 & 10549 \\
\hline
\end{tabular}




\begin{tabular}{|c|c|c|c|c|c|c|c|}
\hline API Number & Source & Formation & Latitude & Longitude & GL Elevation (m) & Depth to Top Oriskany (m) & Pressure (kPa) \\
\hline 4703500106 & B & Oriskany & 38.57438 & -81.62234 & 247 & 1551 & 8274 \\
\hline 4703500118 & B & Oriskany & 38.83296 & -81.66288 & 245 & 1536 & 12859 \\
\hline 4703500157 & B & Oriskany & 38.79664 & -81.64842 & 257 & 1573 & 12859 \\
\hline 4703500173 & B & Oriskany & 38.88753 & -81.63591 & 284 & 1593 & 10411 \\
\hline 4703500227 & B & Oriskany & 38.79269 & -81.62356 & 283 & 1594 & 12617 \\
\hline 4703500431 & B & Oriskany & 38.83517 & -81.62202 & 285 & 1604 & 8687 \\
\hline 4703500796 & B & Oriskany & 38.84914 & -81.76850 & 193 & 1390 & 9791 \\
\hline 4703500864 & $B$ & Oriskany & 39.05026 & -81.74749 & 268 & 1359 & 9239 \\
\hline 4703500978 & B & Oriskany & 39.03703 & -81.67609 & 296 & 1455 & 11652 \\
\hline 4703501330 & $B$ & Oriskany & 38.71363 & -81.77915 & 221 & 1473 & 9997 \\
\hline 4703900043 & $\mathrm{~B}$ & Oriskany & 38.24173 & -81.65463 & 283 & 1408 & 8619 \\
\hline 4703900074 & B & Oriskany & 38.25030 & -81.57351 & 228 & 1388 & 8825 \\
\hline 4703900142 & $B$ & Oriskany & 38.29777 & -81.53461 & 291 & 1471 & 8929 \\
\hline 4703900238 & $\mathrm{~B}$ & Oriskany & 38.28876 & -81.52872 & 383 & 1559 & 6619 \\
\hline 4704100049 & $\mathrm{~B}$ & Oriskany & 39.08029 & -80.53051 & 372 & 2105 & 15065 \\
\hline 4704300182 & $B$ & Oriskany & 38.12632 & -82.02903 & 272 & 1294 & 2565 \\
\hline 4704500223 & $B$ & Oriskany & 38.01329 & -81.97725 & 299 & 1245 & 3034 \\
\hline 4704901077 & $\mathrm{~B}$ & Oriskany & 39.54022 & -80.31284 & 375 & 2414 & 12411 \\
\hline 4705300106 & $\mathrm{~B}$ & Oriskany & 38.82912 & -81.89039 & 215 & 1295 & 8274 \\
\hline 4705700002 & $B$ & Oriskany & 39.43498 & -79.02188 & 560 & 2659 & 16203 \\
\hline 4705700016 & $\mathrm{~B}$ & Oriskany & 39.41304 & -79.03553 & 570 & 2591 & 25049 \\
\hline 4705700022 & $\mathrm{~B}$ & Oriskany & 39.40201 & -79.04544 & 585 & 2609 & 24594 \\
\hline 4705700023 & $B$ & Oriskany & 39.36892 & -78.86400 & 284 & 547 & 3275 \\
\hline 4705700030 & $\mathrm{~B}$ & Oriskany & 39.37342 & -78.87878 & 242 & 479 & 3172 \\
\hline 4705900641 & $\mathrm{C}$ & Oriskany & 37.63161 & -81.87895 & 350 & 1657 & 7412 \\
\hline 4705900786 & $B$ & Oriskany & 37.65175 & -81.90393 & 472 & 1757 & 5033 \\
\hline 4705900850 & $\mathrm{~B}$ & Oriskany & 37.63898 & -81.85055 & 545 & 1865 & 5792 \\
\hline 4706100289 & B & Oriskany & 39.52218 & -79.88317 & 660 & 2361 & 24132 \\
\hline
\end{tabular}




\begin{tabular}{|c|c|c|c|c|c|c|c|}
\hline API Number & Source & Formation & Latitude & Longitude & GL Elevation (m) & Depth to Top Oriskany (m) & Pressure (kPa) \\
\hline 4706100335 & B & Oriskany & 39.56205 & -79.85628 & 668 & 2489 & 21029 \\
\hline 4706100568 & B & Oriskany & 39.61146 & -79.84536 & 634 & 2443 & 24132 \\
\hline 4706100599 & B & Oriskany & 39.46408 & -79.90737 & 571 & 2355 & 22408 \\
\hline 4706101057 & B & Oriskany & 39.69063 & -79.78303 & 637 & 2366 & 21719 \\
\hline 4706101078 & B & Oriskany & 39.52454 & -79.92791 & 511 & 2326 & 20340 \\
\hline 4706101246 & B & Oriskany & 39.55068 & -79.91704 & 465 & 2290 & 16375 \\
\hline 4706101282 & B & Oriskany & 39.58872 & -79.87474 & 599 & 2480 & 11032 \\
\hline 4706101368 & $B$ & Oriskany & 39.47054 & -79.95332 & 521 & 2335 & 18961 \\
\hline 4706101373 & B & Oriskany & 39.59786 & -79.86275 & 436 & 2193 & 21029 \\
\hline 4706101395 & $B$ & Oriskany & 39.62094 & -79.84195 & 597 & 2356 & 24132 \\
\hline 4706500003 & $\mathrm{~B}$ & Oriskany & 39.58553 & -78.43412 & 168 & 1438 & 13790 \\
\hline 4706500004 & B & Oriskany & 39.58524 & -78.43787 & 169 & 1362 & 13672 \\
\hline 4707100013 & $B$ & Oriskany & 38.74623 & -79.46240 & 877 & 2323 & 13100 \\
\hline 4707100016 & $\mathrm{~B}$ & Oriskany & 38.66464 & -79.54145 & 1113 & 2467 & 15741 \\
\hline 4707301314 & $B$ & Oriskany & 39.44440 & -81.08932 & 280 & 1829 & 14183 \\
\hline 4707500004 & $B$ & Oriskany & 38.65302 & -79.76943 & 982 & 1729 & 12728 \\
\hline 4707500010 & $B$ & Oriskany & 38.70238 & -79.74812 & 1067 & 1805 & 13686 \\
\hline 4707500024 & $\mathrm{~B}$ & Oriskany & 38.51307 & -79.69530 & 1173 & 1739 & 11307 \\
\hline 4707500049 & $\mathrm{~B}$ & Oriskany & 38.53252 & -79.69068 & 1024 & 1814 & 7998 \\
\hline 4707500050 & C & Oriskany & 38.61832 & -79.64532 & 1139 & 1792 & 8791 \\
\hline 4707700005 & $\mathrm{~B}$ & Oriskany & 39.43231 & -79.56575 & 608 & 1850 & 15996 \\
\hline 4707700010 & $\mathrm{~B}$ & Oriskany & 39.42047 & -79.57452 & 579 & 1576 & 14755 \\
\hline 4707700013 & $C$ & Oriskany & 39.43387 & -79.57246 & 656 & 1649 & 12928 \\
\hline 4707700017 & $\mathrm{~B}$ & Oriskany & 39.41231 & -79.58019 & 613 & 1551 & 12907 \\
\hline 4707700020 & C & Oriskany & 39.40810 & -79.58169 & 669 & 1600 & 10315 \\
\hline 4707700025 & $B$ & Oriskany & 39.42672 & -79.57357 & 703 & 1703 & 10342 \\
\hline 4707700028 & $\mathrm{~B}$ & Oriskany & 39.41481 & -79.57501 & 639 & 1598 & 10480 \\
\hline 4707700061 & B & Oriskany & 39.26999 & -79.49884 & 776 & 1500 & 12928 \\
\hline
\end{tabular}




\begin{tabular}{|c|c|c|c|c|c|c|c|}
\hline API Number & Source & Formation & Latitude & Longitude & GL Elevation (m) & Depth to Top Oriskany (m) & Pressure (kPa) \\
\hline 4707700065 & B & Oriskany & 39.26415 & -79.50349 & 775 & 1518 & 7929 \\
\hline 4707700068 & B & Oriskany & 39.36778 & -79.60068 & 573 & 1524 & 9101 \\
\hline 4707700094 & B & Oriskany & 39.34118 & -79.62855 & 738 & 1832 & 11859 \\
\hline 4707700127 & B & Oriskany & 39.50814 & -79.86406 & 594 & 2469 & 23773 \\
\hline 4707700253 & B & Oriskany & 39.49681 & -79.49873 & 839 & 2191 & 19305 \\
\hline 4707700284 & B & Oriskany & 39.70282 & -79.76389 & 713 & 2368 & 22408 \\
\hline 4707700319 & B & Oriskany & 39.46923 & -79.85708 & 529 & 2353 & 18961 \\
\hline 4707700320 & $\mathrm{~B}$ & Oriskany & 39.58072 & -79.69065 & 625 & 2464 & 15169 \\
\hline 4707700321 & B & Oriskany & 39.48607 & -79.88734 & 554 & 2321 & 22408 \\
\hline 4707900204 & $\mathrm{~B}$ & Oriskany & 38.61315 & -81.74124 & 272 & 1530 & 11783 \\
\hline 4707900221 & $\mathrm{~B}$ & Oriskany & 38.52532 & -81.78736 & 229 & 1458 & 5102 \\
\hline 4707900228 & B & Oriskany & 38.64781 & -81.72138 & 296 & 1581 & 6826 \\
\hline 4707900241 & $\mathrm{~B}$ & Oriskany & 38.66974 & -81.74790 & 225 & 1491 & 5585 \\
\hline 4707900246 & $\mathrm{~B}$ & Oriskany & 38.66605 & -81.74186 & 216 & 1487 & 11721 \\
\hline 4707900249 & B & Oriskany & 38.64331 & -81.72988 & 236 & 1515 & 7963 \\
\hline 4707900272 & $\mathrm{~B}$ & Oriskany & 38.66052 & -81.74561 & 237 & 1507 & 9377 \\
\hline 4707900324 & $\mathrm{~B}$ & Oriskany & 38.60387 & -81.77001 & 218 & 1470 & 12617 \\
\hline 4707900348 & $\mathrm{~B}$ & Oriskany & 38.58452 & -81.76726 & 301 & 1549 & 12617 \\
\hline 4707900380 & $\mathrm{~B}$ & Oriskany & 38.56826 & -81.77225 & 242 & 1483 & 12135 \\
\hline 4707900394 & $\mathrm{~B}$ & Oriskany & 38.55994 & -81.77824 & 312 & 1529 & 11032 \\
\hline 4707900410 & $\mathrm{~B}$ & Oriskany & 38.55217 & -81.78076 & 267 & 1515 & 10273 \\
\hline 4707900431 & $\mathrm{~B}$ & Oriskany & 38.54985 & -81.77661 & 252 & 1494 & 7998 \\
\hline 4707900441 & $\mathrm{~B}$ & Oriskany & 38.54844 & -81.78515 & 249 & 1487 & 7722 \\
\hline 4707900452 & $\mathrm{~B}$ & Oriskany & 38.56245 & -81.78184 & 273 & 1511 & 6205 \\
\hline 4707900454 & $\mathrm{~B}$ & Oriskany & 38.54215 & -81.77804 & 251 & 1494 & 8067 \\
\hline 4707900458 & $B$ & Oriskany & 38.65428 & -81.76888 & 226 & 1488 & 10790 \\
\hline 4707900459 & $\mathrm{~B}$ & Oriskany & 38.55093 & -81.79691 & 213 & 1439 & 7929 \\
\hline 4707900469 & B & Oriskany & 38.53818 & -81.78196 & 253 & 1497 & 7757 \\
\hline
\end{tabular}




\begin{tabular}{|c|c|c|c|c|c|c|c|}
\hline API Number & Source & Formation & Latitude & Longitude & GL Elevation $(\mathrm{m})$ & Depth to Top Oriskany (m) & Pressure (kPa) \\
\hline 4707900487 & B & Oriskany & 38.54186 & -81.78694 & 148 & 1516 & 5654 \\
\hline 4707900531 & B & Oriskany & 38.52919 & -81.79241 & 264 & 1511 & 5688 \\
\hline 4707900545 & B & Oriskany & 38.50252 & -87.78278 & 273 & 1488 & 7929 \\
\hline 4707900553 & B & Oriskany & 38.50569 & -81.93484 & 202 & 1334 & 4826 \\
\hline 4707900556 & B & Oriskany & 38.49576 & -81.78308 & 251 & 1459 & 8101 \\
\hline 4707900577 & B & Oriskany & 38.46775 & -81.79156 & 197 & 1396 & 11583 \\
\hline 4707900583 & B & Oriskany & 38.45872 & -81.77006 & 175 & 1369 & 12135 \\
\hline 4707900692 & $\mathrm{~B}$ & Oriskany & 38.63824 & -81.74452 & 291 & 1555 & 6550 \\
\hline 4708300047 & B & Oriskany & 38.79123 & -79.68743 & 925 & 1479 & 13445 \\
\hline 4708300058 & $\mathrm{~B}$ & Oriskany & 38.75454 & -79.71322 & 962 & 1475 & 14100 \\
\hline 4708300078 & $\mathrm{~B}$ & Oriskany & 38.73795 & -79.72924 & 969 & 1590 & 13417 \\
\hline 4708300082 & B & Oriskany & 38.90044 & -79.62398 & 888 & 1844 & 11032 \\
\hline 4708300084 & $\mathrm{~B}$ & Oriskany & 38.77280 & -79.70870 & 921 & 1477 & 13927 \\
\hline 4708300087 & $\mathrm{~B}$ & Oriskany & 38.80478 & -79.68319 & 940 & 1588 & 13859 \\
\hline 4708300091 & B & Oriskany & 38.72385 & -79.74255 & 1016 & 1712 & 13445 \\
\hline 4708300097 & $\mathrm{C}$ & Oriskany & 38.81316 & -79.67742 & 903 & 1608 & 10315 \\
\hline 4708300099 & $\mathrm{~B}$ & Oriskany & 38.83169 & -79.66509 & 1005 & 1907 & 8101 \\
\hline 4708300122 & $B$ & Oriskany & 38.75168 & -79.71829 & 1088 & 1641 & 11514 \\
\hline 4708300386 & $\mathrm{~B}$ & Oriskany & 38.65882 & -80.23757 & 849 & 2326 & 8619 \\
\hline 4708300545 & $\mathrm{~B}$ & Oriskany & 38.60642 & -79.86381 & 1134 & 2501 & 10687 \\
\hline 4708300711 & $\mathrm{C}$ & Oriskany & 38.67844 & -79.85813 & 1106 & 2540 & 15858 \\
\hline 4708300822 & $\mathrm{~B}$ & Oriskany & 38.96168 & -79.50501 & 668 & 2112 & 18382 \\
\hline 4708300846 & $B$ & Oriskany & 38.97446 & -79.49863 & 668 & 2118 & 17237 \\
\hline 4708300884 & $\mathrm{~B}$ & Oriskany & 38.76525 & -79.58263 & 961 & 2266 & 14479 \\
\hline 4708300904 & $\mathrm{C}$ & Oriskany & 38.62224 & -79.88941 & 1131 & 2503 & 16548 \\
\hline 4708301033 & $B$ & Oriskany & 38.63604 & -79.89017 & 1143 & 2518 & 19650 \\
\hline 4708301173 & $\mathrm{~B}$ & Oriskany & 38.94324 & -80.05988 & 698 & 2359 & 11032 \\
\hline 4708701575 & B & Oriskany & 38.65070 & -81.28627 & 274 & 1722 & 8274 \\
\hline
\end{tabular}




\begin{tabular}{|c|c|c|c|c|c|c|c|}
\hline API Number & Source & Formation & Latitude & Longitude & GL Elevation (m) & Depth to Top Oriskany (m) & Pressure (kPa) \\
\hline 4708703853 & B & Oriskany & 38.78615 & -81.30650 & 277 & 1784 & 7240 \\
\hline 4708703856 & B & Oriskany & 38.78020 & -81.31020 & 317 & 1819 & 6895 \\
\hline 4708704031 & B & Oriskany & 38.69498 & -81.25259 & 317 & 1795 & 6895 \\
\hline 4708704050 & B & Oriskany & 38.74623 & -81.23350 & 280 & 1795 & 6895 \\
\hline 4709300001 & B & Oriskany & 39.08044 & -79.39784 & 1020 & 2429 & 22063 \\
\hline 4709300002 & C & Oriskany & 39.06310 & -79.40547 & 1019 & 2515 & 20684 \\
\hline 4709300003 & B & Oriskany & 39.09771 & -79.38746 & 1005 & 2455 & 15720 \\
\hline 4709300022 & $B$ & Oriskany & 39.23074 & -79.75269 & 552 & 1347 & 13341 \\
\hline 4709300027 & B & Oriskany & 39.23737 & -79.74728 & 506 & 1305 & 11032 \\
\hline 4709300030 & $B$ & Oriskany & 39.24594 & -79.74150 & 587 & 1412 & 10983 \\
\hline 4709300050 & $\mathrm{~B}$ & Oriskany & 39.04542 & -79.43951 & 986 & 2531 & 7584 \\
\hline 4709300054 & $\mathrm{~B}$ & Oriskany & 39.02351 & -79.44327 & 1000 & 2505 & 16203 \\
\hline 4709500976 & $B$ & Oriskany & 39.50016 & -81.08138 & 191 & 1710 & 14348 \\
\hline 4709702777 & $\mathrm{~B}$ & Oriskany & 38.82956 & -80.39057 & 500 & 2252 & 7584 \\
\hline 4709703022 & $B$ & Oriskany & 38.84249 & -80.32837 & 539 & 2204 & 16892 \\
\hline 4710300645 & $B$ & Oriskany & 39.67814 & -80.82395 & 411 & 2091 & 13790 \\
\hline 4710700169 & $B$ & Oriskany & 39.33246 & -81.47625 & 205 & 1439 & 7584 \\
\hline 4710700288 & $\mathrm{~B}$ & Oriskany & 39.04734 & -81.55841 & 311 & 1629 & 12928 \\
\hline 4710700320 & $\mathrm{~B}$ & Oriskany & 39.08393 & -81.54036 & 261 & 1529 & 7446 \\
\hline 4710700375 & $B$ & Oriskany & 39.21430 & -81.70654 & 269 & 1326 & 10756 \\
\hline 4710700384 & $\mathrm{~B}$ & Oriskany & 39.20893 & -81.69928 & 259 & 1329 & 10756 \\
\hline 4710700385 & $\mathrm{~B}$ & Oriskany & 39.20108 & -81.72343 & 213 & 1257 & 11549 \\
\hline 4710700386 & $B$ & Oriskany & 39.19788 & -81.72976 & 189 & 1230 & 11549 \\
\hline 4710700387 & $\mathrm{~B}$ & Oriskany & 39.21168 & -81.69182 & 214 & 1293 & 11170 \\
\hline 4710700391 & $B$ & Oriskany & 39.20442 & -81.69667 & 235 & 1312 & 11170 \\
\hline 4710700392 & $B$ & Oriskany & 39.19730 & -81.71132 & 190 & 1250 & 11445 \\
\hline 4710700395 & $\mathrm{~B}$ & Oriskany & 39.19077 & -81.70412 & 200 & 1269 & 10894 \\
\hline 4710700611 & B & Oriskany & 39.19812 & -81.42551 & 235 & 1595 & 9308 \\
\hline
\end{tabular}




\begin{tabular}{|l|c|c|c|c|c|c|c|}
\hline API Number & Source & Formation & Latitude & Longitude & GL Elevation $(\mathbf{m})$ & Depth to Top Oriskany (m) & Pressure (kPa) \\
\hline 4710701053 & B & Oriskany & 39.26830 & -81.65673 & 194 & 1275 & 10342 \\
\hline 4710701303 & B & Oriskany & 39.14461 & -81.54390 & 195 & 1451 & 8274 \\
\hline 4710701309 & B & Oriskany & 39.24811 & -81.60812 & 205 & 1331 & 5171 \\
\hline
\end{tabular}

Source: $\quad$ A-Ohio Stat Division of Natural Resources website http://www.dnr.state.oh.us

B-West Virginia Geologic and Economic Survey website http://www.wvgs.wvnet.edu

C-Chesapeake Energy

All data used in this study are available on the West Virginia GIS Technical Center website http://wvgis.wvu.edu. 
Appendix III

Oriskany Sandstone Geochemical Data 
Oriskany Sandstone geochemical data.

\begin{tabular}{|c|c|c|c|c|c|c|c|c|}
\hline Sample/API Number & Source & Horizon & Latitude & Longitude & GL Elevation (m) & Depth/Top (m) & Depth/Base (m) & TDS Calculated (mg/L) \\
\hline 3407321971 & $\mathrm{C}$ & Oriskany & 39.51075 & -82.5557 & 340 & 665 & & 194292 \\
\hline 3705120737 & $\mathrm{C}$ & Oriskany & 39.78439 & -79.75071 & & & & 341633 \\
\hline 3711720158 & $\mathrm{C}$ & Oriskany & 41.76024 & -76.99193 & 522 & 2038 & & 385500 \\
\hline 3711720159 & $\mathrm{C}$ & Oriskany & 41.45374 & -76.59301 & 523 & 2039 & & 277375 \\
\hline 4700500567 & $\mathrm{C}$ & Oriskany & 38.20717 & -81.65403 & 299 & 1393 & 1397 & 246321 \\
\hline 4700700226 & $\mathrm{H}$ & Oriskany & 38.68439 & -80.82756 & 352 & 1914 & & 246819 \\
\hline 4700700447 & $\mathrm{~J}$ & Oriskany & 38.79923 & -80.55487 & 269 & 2101 & & 80000 \\
\hline 4701502426 & $\mathrm{C}$ & Oriskany & 38.38474 & -81.25295 & 436 & 1900 & 1909 & 222949 \\
\hline 4702300005 & $\mathrm{C}$ & Oriskany & 39.04240 & -79.28571 & 912 & 2525 & 2622 & 102548 \\
\hline 4702300007 & $\mathrm{C}$ & Oriskany & 39.95471 & -79.32992 & 825 & 2563 & 2624 & 187404 \\
\hline 4702300008 & $\mathrm{C}$ & Oriskany & 39.12748 & -79.24653 & 796 & 2448 & 2558 & 23908 \\
\hline 4702300009 & $\mathrm{C}$ & Oriskany & 39.96604 & -79.32082 & 834 & 2508 & & 128344 \\
\hline 4702300010 & $\mathrm{C}$ & Oriskany & 39.14823 & -79.23740 & 805 & 2504 & 2611 & 204038 \\
\hline 4702300011 & C & Oriskany & 39.18613 & -79.21765 & 879 & 2716 & 2789 & 90079 \\
\hline 4702300012 & $\mathrm{C}$ & Oriskany & 39.08072 & -79.26823 & 815 & 2524 & 2586 & 110545 \\
\hline 4702300013 & $\mathrm{C}$ & Oriskany & 39.09597 & -79.27809 & 904 & 2650 & 2710 & 197705 \\
\hline 4702300014 & $\mathrm{C}$ & Oriskany & 39.11528 & -79.25558 & 645 & 2319 & 2382 & 207709 \\
\hline 4702300015 & $\mathrm{C}$ & Oriskany & 39.05692 & -79.27511 & 765 & 2423 & 2488 & 35011 \\
\hline 4702300017 & $\mathrm{C}$ & Oriskany & 39.02178 & -79.29464 & 868 & 2582 & & 163637 \\
\hline 4702300018 & $\mathrm{C}$ & Oriskany & 39.06824 & -79.26191 & 698 & 2376 & 2443 & 22236 \\
\hline 4702300019 & $\mathrm{C}$ & Oriskany & 39.26119 & -79.18189 & 959 & 2973 & 3042 & 188919.3 \\
\hline 4702300020 & $\mathrm{C}$ & Oriskany & 39.07332 & -79.29409 & 1055 & 2830 & 2891 & 166400 \\
\hline 4702300021 & $\mathrm{C}$ & Oriskany & 39.07782 & -79.25428 & 611 & 2381 & & 13091 \\
\hline 4702300023 & C & Oriskany & 39.10715 & -79.26953 & 829 & 2557 & 2621 & 249278 \\
\hline 4702300030 & $\mathrm{C}$ & Oriskany & 39.28557 & -79.15300 & 814 & 2833 & & 83778 \\
\hline 4702300032 & $\mathrm{C}$ & Oriskany & 39.09612 & -79.24944 & 596 & 2359 & 2390 & 17594 \\
\hline 4703100016 & $*$ & Oriskany & 38.93801 & -78.90081 & 674 & 2025 & 2096 & 29655 \\
\hline 4703500022 & $\mathrm{H}$ & Oriskany & 38.69528 & -81.54256 & 296 & 1677 & 1680 & 266694 \\
\hline 4703500024 & $\mathrm{H}$ & Oriskany & 38.65926 & -81.54996 & 300 & 1659 & & 266019 \\
\hline 4703500041 & $\mathrm{H}$ & Oriskany & 38.59932 & -81.63977 & 200 & 1512 & & 138199 \\
\hline
\end{tabular}




\begin{tabular}{|c|c|c|c|c|c|c|c|c|}
\hline Sample/API Number & Source & Horizon & Latitude & Longitude & GL Elevation (m) & Depth/Top (m) & Depth/Base (m) & TDS Calculated (mg/L) \\
\hline 4703500053 & $\mathrm{H}$ & Oriskany & 38.57157 & -81.59830 & 254 & 1555 & & 259914 \\
\hline 4703500077 & $\mathrm{H}$ & Oriskany & 38.57535 & -81.64983 & 288 & 1609 & & 268146 \\
\hline 4703500094 & $\mathrm{C}$ & Oriskany & 38.60634 & -81.65371 & 213 & 1509 & & 338377 \\
\hline 4703500103 & $\mathrm{H}$ & Oriskany & 38.94282 & -81.58816 & 204 & 1546 & & 264713 \\
\hline 4703500104 & $\mathrm{C}$ & Oriskany & 38.60925 & -81.62882 & 276 & 1586 & & 92342 \\
\hline 4703500112 & $\mathrm{H}$ & Oriskany & 38.95341 & -81.62567 & 211 & 1523 & & 262276 \\
\hline 4703500198 & $\mathrm{H}$ & Oriskany & 38.86180 & -81.61973 & 211 & 1644 & & 275968 \\
\hline 4703500223 & $\mathrm{H}$ & Oriskany & 38.82898 & -81.61559 & 195 & 1532 & & 175678 \\
\hline 4703500224 & $\mathrm{H}$ & Oriskany & 38.61543 & -81.58049 & 208 & 1543 & & 239231 \\
\hline 4703500225 & $\mathrm{C}$ & Oriskany & 38.61878 & -81.64038 & 234 & 1536 & & 315133 \\
\hline 4703500272 & $\mathrm{C}$ & Oriskany & 38.74753 & -81.63530 & 256 & 1579 & & 270117 \\
\hline 4703500273 & $\mathrm{C}$ & Oriskany & 38.74394 & -81.64003 & 269 & 1589 & & 278947 \\
\hline 4703500308 & $\mathrm{H}$ & Oriskany & 38.91959 & -81.60821 & 235 & 1579 & & 239793 \\
\hline 4703500312 & $\mathrm{H}$ & Oriskany & 38.79386 & -81.61874 & 213 & 1549 & & 267695 \\
\hline 4703500332 & $\mathrm{H}$ & Oriskany & 38.86413 & -81.59392 & 213 & 1597 & & 241390 \\
\hline 4703500337 & $\mathrm{H}$ & Oriskany & 38.91623 & -81.61323 & 285 & 1628 & & 226768 \\
\hline 4703500381 & $\mathrm{H}$ & Oriskany & 38.63067 & -81.64995 & 248 & 1561 & & 264309 \\
\hline 4703500398 & $\mathrm{H}$ & Oriskany & 38.78094 & -81.62115 & 273 & 1610 & & 267683 \\
\hline 4703500413 & $\mathrm{C}$ & Oriskany & 38.77699 & -81.62970 & 303 & 1625 & & 178745 \\
\hline 4703500419 & $\mathrm{C}$ & Oriskany & 38.76065 & -81.64656 & 190 & 1503 & 1519 & 342271 \\
\hline 4703500441 & $\mathrm{H}$ & Oriskany & 38.75161 & -81.62059 & 253 & 1590 & & 270323 \\
\hline 4703500486 & $\mathrm{C}$ & Oriskany & 38.8843 & -81.6815 & 201 & 1481 & 1498 & 55722 \\
\hline 4703500512 & $\mathrm{C}$ & Oriskany & 38.83755 & -81.6789 & 208 & 1502 & & 217147 \\
\hline 4703500531 & $\mathrm{C}$ & Oriskany & 38.85337 & -81.6947 & 225 & 1504 & & 148323 \\
\hline 4703500911 & $\mathrm{C}$ & Oriskany & 38.88024 & -81.6954 & 223 & 1498 & & 99380 \\
\hline 4703502408 & $\mathrm{C}$ & Oriskany & 38.8239 & -81.6811 & 225 & 1512 & & 202822 \\
\hline 4703502464 & $\mathrm{C}$ & Oriskany & 38.84409 & -81.6985 & 184 & 1462 & 1472 & 82199 \\
\hline 4703900222 & $\mathrm{I}$ & Oriskany & 38.27818 & -81.50221 & 345 & 1550 & 1551 & 238989 \\
\hline 4703900226 & $\mathrm{I}$ & Oriskany & 38.43875 & -81.35657 & 382 & 1761 & & 262164 \\
\hline 4703900269 & 1 & Oriskany & 38.26830 & -81.50828 & 405 & 1600 & & 233580 \\
\hline 4703900321 & $\mathrm{H}$ & Oriskany & 38.44919 & -81.57264 & 280 & 1523 & & 271551 \\
\hline 4703900458 & $\mathrm{H}$ & Oriskany & 38.44615 & -81.58850 & 305 & 1561 & & 264280 \\
\hline
\end{tabular}




\begin{tabular}{|c|c|c|c|c|c|c|c|c|}
\hline Sample/API Number & Source & Horizon & Latitude & Longitude & GL Elevation $(\mathrm{m})$ & Depth/Top (m) & Depth/Base (m) & TDS Calculated (mg/L) \\
\hline 4703900513 & $\mathrm{H}$ & Oriskany & 38.45065 & -81.59200 & 315 & 1569 & & 266696 \\
\hline 4703900696 & $\mathrm{H}$ & Oriskany & 38.52934 & -81.66645 & 261 & 1539 & & 253625 \\
\hline 4703900754 & $\mathrm{H}$ & Oriskany & 38.47315 & -81.44838 & 223 & 1589 & & 273093 \\
\hline 4703900771 & C & Oriskany & 38.56897 & -81.64680 & 232 & 1537 & 1551 & 347133 \\
\hline 4703900926 & $\mathrm{H}$ & Oriskany & 38.45166 & -81.65561 & 217 & 1478 & & 259923 \\
\hline 4703901352 & $\mathrm{C}$ & Oriskany & 38.52411 & -81.4859 & 260 & 1581 & 1594 & 51230 \\
\hline 4703901533 & $\mathrm{C}$ & Oriskany & 38.44865 & -81.4375 & 307 & 1654 & & 92283 \\
\hline 4703905269 & $\mathrm{C}$ & Oriskany & 38.442513 & -81.403 & 368 & 1706 & 1718 & 129349 \\
\hline 4705300260 & $\mathrm{C}$ & Oriskany & 38.77570 & -82.07207 & 211 & & & 216847 \\
\hline 4705500014 & $\mathrm{C}$ & Oriskany & 37.35613 & -81.18628 & 794 & 2385 & 2432 & 77000 \\
\hline 4705700022 & $\mathrm{C}$ & Oriskany & 39.40201 & -79.04544 & 585 & 2609 & & 222 \\
\hline 4705900641 & $\mathrm{C}$ & Oriskany & 37.63161 & -81.87895 & 350 & 1657 & 1661 & 48245 \\
\hline 4706100337 & $*$ & Oriskany & 39.58848 & -79.83815 & 608 & 2471 & & 279860 \\
\hline 4706100347 & $*$ & Oriskany & 39.56573 & -79.88614 & 626 & 2446 & 2463 & 271200 \\
\hline 4706900038 & $\mathrm{C}$ & Oriskany & 40.05866 & -80.58205 & 396 & 2060 & 2087 & 216847 \\
\hline 4707100010 & $\mathrm{C}$ & Oriskany & 38.91014 & -79.34745 & 769 & 2594 & 2665 & 185867 \\
\hline 4707100012 & $\mathrm{C}$ & Oriskany & 38.79632 & -79.42260 & 824 & 2458 & 2552 & 76479 \\
\hline 4707500011 & $\mathrm{C}$ & Oriskany & 38.67495 & -79.75759 & 1052 & 1750 & 1809 & 28441 \\
\hline 4707500014 & C & Oriskany & 38.63024 & -79.78072 & 984 & 1815 & 1870 & 195659 \\
\hline 4707500025 & $*$ & Oriskany & 38.68381 & -79.75481 & 1048 & 1771 & 1832 & 282995 \\
\hline 4707500026 & $\mathrm{C}$ & Oriskany & 38.66391 & -79.7635 & 1072 & 1794 & 1863 & 21691 \\
\hline 4707500033 & $*$ & Oriskany & 38.65999 & -79.7655 & 1014 & 1740 & 1800 & 37090 \\
\hline 4707500034 & $\mathrm{C}$ & Oriskany & 38.66769 & -79.76184 & 1063 & 1806 & & 42737 \\
\hline 4707700013 & $\mathrm{C}$ & Oriskany & 39.43387 & -79.57246 & 656 & 1649 & 1699 & 89348 \\
\hline 4707700021 & C & Oriskany & 39.41043 & -79.57720 & 685 & & & 122512 \\
\hline 4707700025 & $*$ & Oriskany & 39.42672 & -79.57357 & 703 & & & 176969 \\
\hline 4707700058 & $\mathrm{C}$ & Oriskany & 39.40331 & -79.59137 & 536 & 1419 & 1451 & 259414 \\
\hline 4707700090 & $\mathrm{H}$ & Oriskany & 39.35337 & -79.60835 & 784 & 1835 & 1875 & \\
\hline 4707700141 & $\mathrm{C}$ & Oriskany & 39.38034 & -79.58653 & 610 & 1609 & 1649 & 30887 \\
\hline 4707700143 & $\mathrm{C}$ & Oriskany & 39.36482 & -79.60156 & 680 & 1651 & 1690 & 313023 \\
\hline 4707700155 & $\mathrm{C}$ & Oriskany & 39.38197 & -79.58294 & 610 & 1603 & 1644 & 198626 \\
\hline 4707700156 & C & Oriskany & 39.37754 & -79.59483 & 631 & 1568 & 1608 & 340920 \\
\hline
\end{tabular}




\begin{tabular}{|c|c|c|c|c|c|c|c|c|}
\hline Sample/API Number & Source & Horizon & Latitude & Longitude & GL Elevation $(\mathrm{m})$ & Depth/Top (m) & Depth/Base (m) & TDS Calculated (mg/L) \\
\hline 4707700158 & $\mathrm{C}$ & Oriskany & 39.36237 & -79.59397 & 775 & 1810 & 1851 & 130370 \\
\hline 4707700162 & $*$ & Oriskany & 39.35409 & -79.62037 & 617 & 1611 & 1650 & 324460 \\
\hline 4707700164 & $\mathrm{C}$ & Oriskany & 39.33534 & -79.62316 & 794 & 1953 & 1993 & 202318 \\
\hline 4707700166 & $\mathrm{C}$ & Oriskany & 39.42145 & -79.54762 & 815 & 2010 & 2046 & 255943 \\
\hline 4707700186 & $*$ & Oriskany & 39.51110 & -79.83121 & 540 & 2368 & 2391 & 292200 \\
\hline 4707700316 & $\mathrm{C}$ & Oriskany & 39.53456 & -79.85094 & 566 & 2358 & 2393 & 255943 \\
\hline 4707900031 & $\mathrm{C}$ & Oriskany & 38.42908 & -81.85005 & 180 & 1321 & 1322 & 114035 \\
\hline 4707900204 & $\mathrm{H}$ & Oriskany & 38.61311 & -81.74124 & 272 & 1547 & & 266039 \\
\hline 4708100289 & $\mathrm{C}$ & Oriskany & 37.828689 & -81.31032 & 548 & 2000 & 2004 & 75000 \\
\hline 4708300002 & $\mathrm{H}$ & Oriskany & 38.78442 & -79.91600 & 619 & 1135 & 1153 & 107840 \\
\hline 4708300096 & $\mathrm{C}$ & Oriskany & 38.75422 & -79.723 & 990 & 1572 & & 3622 \\
\hline 4708300097 & $\mathrm{C}$ & Oriskany & 38.81316 & -79.67742 & 903 & 1608 & & 97453 \\
\hline 4708300118 & C & Oriskany & 38.78203 & -79.69855 & 987 & 1516 & 1576 & 136876 \\
\hline 4708300124 & $\mathrm{C}$ & Oriskany & 38.74918 & -79.7216 & 1061 & 1624 & 1698 & 1836 \\
\hline 4708300126 & $\mathrm{C}$ & Oriskany & 38.79111 & -79.69454 & 985 & 1601 & 1664 & 185113 \\
\hline 4708300612 & $\mathrm{C}$ & Oriskany & 38.75186 & -80.11867 & 945 & & & 225130 \\
\hline 4708300904 & $\mathrm{C}$ & Oriskany & 38.62224 & -79.88941 & 1131 & 2503 & 2559 & 191039 \\
\hline 4708700239 & 1 & Oriskany & 38.61978 & -81.14033 & 314 & 1822 & & 222755 \\
\hline 4708700413 & $\mathrm{H}$ & Oriskany & 38.55924 & -81.39392 & 309 & 1676 & & 275327 \\
\hline 4708700429 & $\mathrm{H}$ & Oriskany & 38.60787 & -81.51940 & 207 & 1544 & & 272738 \\
\hline 4708701200 & $\mathrm{~J}$ & Oriskany & 38.60874 & -81.31771 & 279 & 1682 & & 37000 \\
\hline 4708900005 & $C$ & Oriskany & 37.69236 & -80.95206 & 553 & 2128 & 2134 & 38000 \\
\hline 4709300002 & $\mathrm{C}$ & Oriskany & 39.06310 & -79.40547 & 1019 & 2515 & 2554 & 230964 \\
\hline 4709702852 & $\mathrm{C}$ & Oriskany & 38.69745 & -80.28997 & 812 & 2370 & 2436 & 253721 \\
\hline 4709900393 & $\mathrm{H}$ & Oriskany & 38.23142 & -82.55329 & 231 & 928 & & 121699 \\
\hline 4710500068 & $\mathrm{I}$ & Oriskany & 38.99318 & -81.30763 & 254 & 1494 & 1495 & 274294 \\
\hline 4710500091 & $\mathrm{H}$ & Oriskany & 39.02368 & -81.30413 & 265 & 1488 & & \\
\hline 4710500171 & $\mathrm{H}$ & Oriskany & 38.91115 & -81.36267 & 246 & 1724 & & 255999 \\
\hline 4710500531 & $\mathrm{~J}$ & Oriskany & 38.95428 & -81.29141 & 320 & 1807 & 1818 & 294197 \\
\hline 4710700306 & C & Oriskany & 39.05808 & -81.5502 & 329 & 1640 & & 222516 \\
\hline 4710700336 & $\mathrm{C}$ & Oriskany & 39.07782 & -81.5357 & 300 & 1598 & & 226438 \\
\hline 4710700346 & $\mathrm{C}$ & Oriskany & 39.07985 & -81.53311 & 290 & 1586 & & 235513 \\
\hline
\end{tabular}




\begin{tabular}{|c|c|c|c|c|c|c|c|c|}
\hline Sample/API Number & Source & Horizon & Latitude & Longitude & GL Elevation (m) & Depth/Top (m) & Depth/Base (m) & TDS Calculated (mg/L) \\
\hline 4710700351 & $\mathrm{~J}$ & Oriskany & 39.25698 & -81.27240 & 324 & 1323 & & 190000 \\
\hline ED-82-37 & $\mathrm{F}$ & Oriskany & 39.97139 & -79.09139 & 646 & 2694 & 2727 & 101000 \\
\hline ED-82-38 & $\mathrm{F}$ & Oriskany & 39.94111 & -79.11944 & 570 & 2676 & 2695 & 230000 \\
\hline ED-82-39 & $\mathrm{F}$ & Oriskany & 39.93361 & -79.11056 & 642 & 2697 & 2729 & 302000 \\
\hline ED-82-40 & $\mathrm{F}$ & Oriskany & 40.04167 & -78.91667 & 718 & 2604 & 2627 & 343000 \\
\hline Maryland_GARCO_G41 & $M$ & Oriskany & 39.65722 & -79.325 & 603 & 2128 & 2166 & 305380 \\
\hline Maryland_WASCO_AC2 & $\mathrm{M}$ & Oriskany & 39.70416 & -78.22916 & 189 & 42 & 43 & 113 \\
\hline Maryland-153 & $*$ & Oriskany & 39.665 & -79.2361 & 893 & 2588 & 2632 & 130960 \\
\hline NewYork_1 & $\mathrm{L}$ & Oriskany & 42.05 & -78.62 & & 1246 & 1252 & 254534 \\
\hline NewYork_2 & $\mathrm{L}$ & Oriskany & 42.11 & -78.17 & & 1430 & 1436 & 306509 \\
\hline NewYork_3 & $\mathrm{L}$ & Oriskany & 42.17 & -78.00 & & 1169 & 1170 & 321261 \\
\hline NewYork_4 & $\mathrm{L}$ & Oriskany & 42.17 & -77.92 & & 1169 & 1181 & 318570 \\
\hline NewYork_5 & $L$ & Oriskany & 42.052 & -77.32 & & 1250 & & 262609 \\
\hline OHIO_12 & $\mathrm{G}$ & Oriskany & 40.85057 & -82.08988 & 357 & 652 & & 252900 \\
\hline OHIO_18 & $\mathrm{G}$ & Oriskany & 41.31122 & -82.09506 & & 384 & 399 & 177900 \\
\hline OHIO_21 & $\mathrm{G}$ & Oriskany & 40.40286 & -80.71155 & 357 & 1568 & 1577 & 316100 \\
\hline OHIO_243 & G & Oriskany & 40.91527 & -81.76897 & 290 & 693 & & 231090 \\
\hline OHIO_244 & G & Oriskany & 41.76928 & -81.28762 & & 457 & & 295700 \\
\hline OHIO_25 & G & Oriskany & 41.20770 & -81.91132 & & 547 & & 273500 \\
\hline OHIO_2545 & G & Oriskany & 39.74174 & -81.65590 & & 1162 & 1167 & 292700 \\
\hline OHIO_287 & G & Oriskany & 41.32416 & -81.53710 & 347 & 753 & & 197550 \\
\hline OHIO_29 & $\mathrm{G}$ & Oriskany & 40.74705 & -82.40302 & 347 & 611 & & 165600 \\
\hline OHIO_3 & $\mathrm{G}$ & Oriskany & 40.92303 & -82.14164 & 337 & 608 & 613 & 251200 \\
\hline OHIO_31 & $\mathrm{G}$ & Oriskany & 41.26723 & -81.95789 & 255 & 463 & 469 & 256100 \\
\hline OHIO_32 & G & Oriskany & 41.15853 & -81.64475 & 318 & 650 & 652 & 246750 \\
\hline OHIO_34 & G & Oriskany & 41.16371 & -81.99154 & 270 & 530 & & 257700 \\
\hline OHIO_3477 & G & Oriskany & 39.65279 & -81.51805 & & 1311 & 1318 & 285000 \\
\hline OHIO_36 & $\mathrm{G}$ & Oriskany & 41.01102 & -82.11317 & 332 & 555 & & 224800 \\
\hline OHIO_37 & $\mathrm{G}$ & Oriskany & 40.83763 & -82.17269 & & 604 & & 246800 \\
\hline OHIO_38 & $\mathrm{G}$ & Oriskany & 40.86868 & -82.28915 & & 515 & & 133700 \\
\hline OHIO_57 & G & Oriskany & 41.40439 & -82.09609 & 191 & 337 & & 168750 \\
\hline OHIO_58 & $\mathrm{G}$ & Oriskany & 41.19994 & -82.01069 & 282 & 475 & & 241900 \\
\hline
\end{tabular}




\begin{tabular}{|c|c|c|c|c|c|c|c|c|}
\hline Sample/API Number & Source & Horizon & Latitude & Longitude & GL Elevation (m) & Depth/Top (m) & Depth/Base (m) & TDS Calculated (mg/L) \\
\hline OHIO_65-88 & $\mathrm{G}$ & Oriskany & 41.90777 & -80.73238 & 190 & 494 & 497 & 284900 \\
\hline OHIO_709 & G & Oriskany & 41.82107 & -81.00393 & 205 & 497 & 498 & 319500 \\
\hline PENN_TULLY_1 & $\mathrm{D}$ & Oriskany & 42.07306 & -80.06202 & 272 & 609 & 611 & 272518 \\
\hline PENN_TULLY_176 & $\mathrm{D}$ & Oriskany & 41.03091 & -78.84634 & 450 & 2213 & 2221 & 327262 \\
\hline PENN_TULLY_177 & $\mathrm{D}$ & Oriskany & 41.05477 & -78.75641 & 485 & 2213 & 2224 & 338440 \\
\hline PENN_TULLY_178 & $\mathrm{D}$ & Oriskany & 41.12063 & -78.74281 & 460 & 2189 & 2192 & 324112 \\
\hline PENN_TULLY_179 & $\mathrm{D}$ & Oriskany & 41.23796 & -78.62943 & 533 & 2241 & 2250 & 191311 \\
\hline PENN_TULLY_181 & $\mathrm{D}$ & Oriskany & 41.23262 & -78.53979 & 478 & 2188 & 2198 & 232255 \\
\hline PENN_TULLY_183 & $\mathrm{D}$ & Oriskany & 40.84483 & -78.44819 & 526 & 2440 & 2446 & 253770 \\
\hline PENN_TULLY_183a & $\mathrm{D}$ & Oriskany & 40.84483 & -78.44819 & 526 & 2449 & & 330389 \\
\hline PENN_TULLY_185 & $\mathrm{D}$ & Oriskany & 41.06146 & -78.81391 & 472 & 2270 & & 328338 \\
\hline PENN_TULLY_185a & $\mathrm{D}$ & Oriskany & 41.06146 & -78.81391 & 472 & 2211 & & 336042 \\
\hline PENN_TULLY_186 & $D$ & Oriskany & 41.21724 & -78.53979 & 352 & 2089 & 2100 & 240329 \\
\hline PENN_TULLY_187 & $\mathrm{D}$ & Oriskany & 41.07349 & -78.73435 & 512 & 2257 & 2266 & 274977 \\
\hline PENN_TULLY_189 & $\mathrm{D}$ & Oriskany & 41.07884 & -78.72566 & 487 & 2207 & 2216 & 190401 \\
\hline PENN_TULLY_190 & $\mathrm{D}$ & Oriskany & 41.08218 & -78.71630 & 471 & 2205 & 2209 & 325408 \\
\hline PENN_TULLY_191 & $\mathrm{D}$ & Oriskany & 41.04140 & -78.77714 & 443 & 2198 & 2207 & 325054 \\
\hline PENN_TULLY_192 & $\mathrm{D}$ & Oriskany & 41.05343 & -78.81325 & 450 & 2212 & 2221 & 316299 \\
\hline PENN_TULLY_193 & $\mathrm{D}$ & Oriskany & 39.82755 & -78.35384 & 331 & 1402 & 1460 & 159797 \\
\hline PENN_TULLY_193a & $D$ & Oriskany & 39.82755 & -78.35384 & 331 & 1437 & & 297592 \\
\hline PENN_TULLY_194 & $\mathrm{D}$ & Oriskany & 40.79758 & -78.99555 & 423 & 2199 & 2208 & 319848 \\
\hline PENN_TULLY_195 & $\mathrm{D}$ & Oriskany & 41.38039 & -78.33475 & 516 & 2089 & 2089 & 268721 \\
\hline PENN_TULLY_196 & $\mathrm{D}$ & Oriskany & 40.85196 & -79.01606 & 479 & 2323 & 2329 & 297265 \\
\hline PENN_TULLY_197 & $\mathrm{D}$ & Oriskany & 41.40103 & -78.28866 & 423 & 2014 & 2024 & 325009 \\
\hline PENN_TULLY_198 & $\mathrm{D}$ & Oriskany & 39.76393 & -78.38837 & 333 & 1515 & & 139277 \\
\hline PENN_TULLY_199 & $D$ & Oriskany & 40.87603 & -78.89214 & 612 & 2306 & & 279698 \\
\hline PENN_TULLY_200 & $\mathrm{D}$ & Oriskany & 40.62273 & -79.41129 & 324 & 2349 & 2354 & 303654 \\
\hline PENN_TULLY_201 & $\mathrm{D}$ & Oriskany & 41.86746 & -77.49424 & 500 & 1325 & 1331 & 595 \\
\hline PENN_TULLY_203 & $\mathrm{D}$ & Oriskany & 41.16105 & -78.67281 & 501 & 2259 & 2267 & 274542 \\
\hline PENN_TULLY_204 & $D$ & Oriskany & 41.06213 & -78.73168 & 449 & 2187 & 2189 & 330058 \\
\hline PENN_TULLY_205 & $\mathrm{D}$ & Oriskany & 41.03781 & -78.78422 & 429 & 2214 & & 250203 \\
\hline PENN_TULLY_209 & $\mathrm{D}$ & Oriskany & 40.10795 & -79.06582 & 629 & 2566 & 2595 & 127477 \\
\hline
\end{tabular}




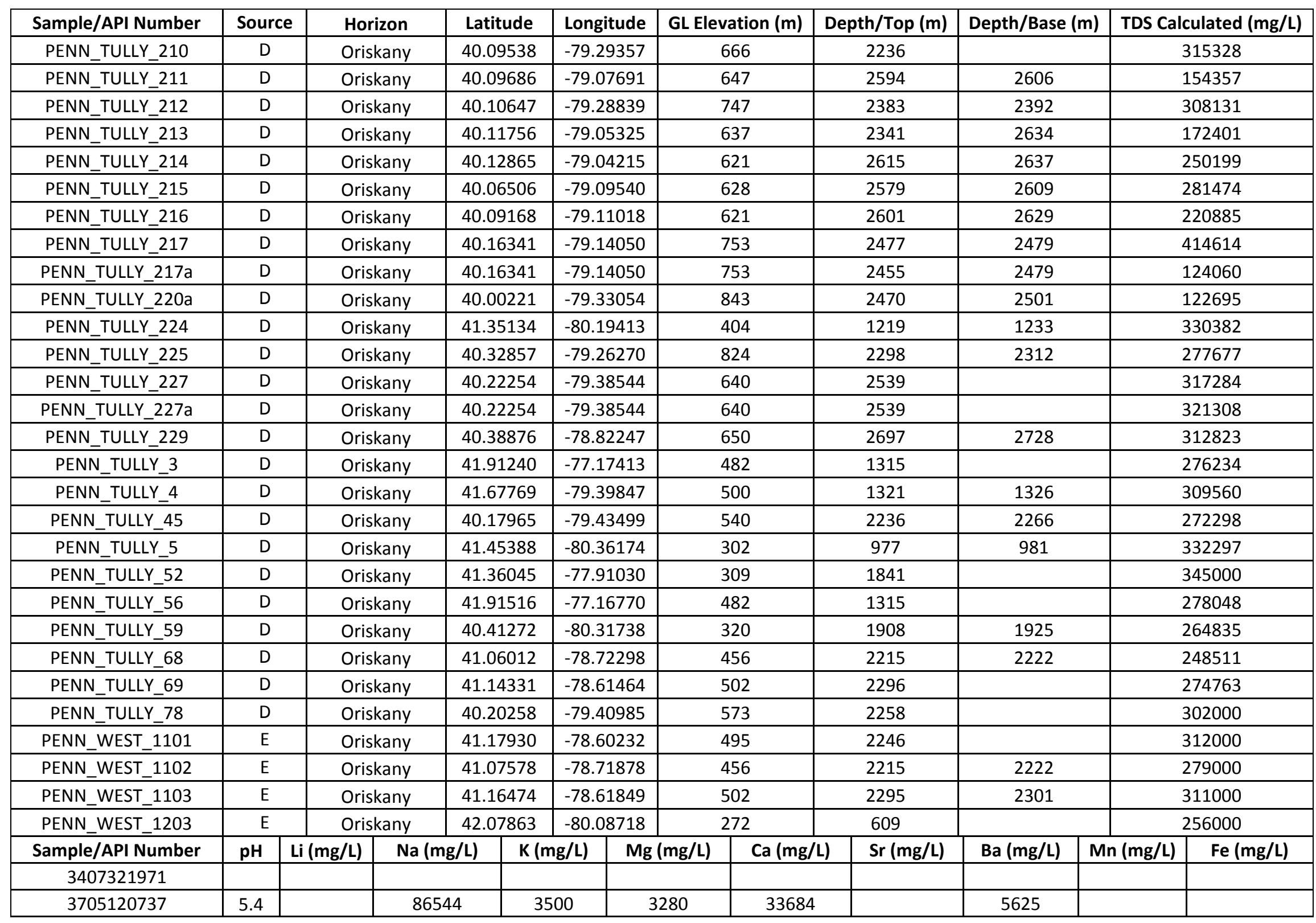




\begin{tabular}{|c|c|c|c|c|c|c|c|c|c|c|}
\hline Sample/API Number & $\mathrm{pH}$ & $\mathrm{Li} \mathrm{(mg/L)}$ & $\mathrm{Na}(\mathrm{mg} / \mathrm{L})$ & $\mathrm{K}(\mathrm{mg} / \mathrm{L})$ & $\mathrm{Mg}(\mathrm{mg} / \mathrm{L})$ & $\mathrm{Ca}(\mathrm{mg} / \mathrm{L})$ & $\mathrm{Sr}(\mathrm{mg} / \mathrm{L})$ & $\mathrm{Ba}(\mathrm{mg} / \mathrm{L})$ & $\mathrm{Mn}(\mathrm{mg} / \mathrm{L})$ & $\mathrm{Fe}(\mathrm{mg} / \mathrm{L})$ \\
\hline 3711720158 & 3 & & 112486 & & 729 & 34085 & & 1875 & & 250 \\
\hline 3711720159 & 4.2 & & 31068 & 0 & 5224 & 63558 & & 1025 & & \\
\hline 4700500567 & & & 61720 & 4400 & 4350 & 22750 & & 1300 & & \\
\hline 4700700226 & & & 69620 & 2350 & 2300 & 19270 & & 880 & & 144 \\
\hline \multicolumn{11}{|l|}{4700700447} \\
\hline 4701502426 & 2 & & 14223 & & 5711 & 59259 & & 0 & & 2200 \\
\hline 4702300005 & 4.7 & & 30690 & 0 & 1166 & 6567 & & 1125 & & \\
\hline 4702300007 & 5.4 & & 56822 & 1 & 1094 & 12613 & & 2375 & & 130 \\
\hline 4702300008 & 5.6 & & 7578 & 0 & 67 & 1532 & & 80 & & 70 \\
\hline 4702300009 & 5.7 & & 38969 & 1 & 1385 & 8328 & & 462 & & 130 \\
\hline 4702300010 & 5.6 & & 60261 & 1 & 1312 & 15215 & & 2250 & & 80 \\
\hline 4702300011 & 6 & & 27880 & 1 & 753 & 5846 & & 0 & & 200 \\
\hline 4702300012 & 4 & & 21868 & & 608 & 18819 & & 0 & & 2500 \\
\hline 4702300013 & 4.4 & & 57097 & 3900 & 4009 & 9824 & & 1375 & & \\
\hline 4702300014 & 4.8 & & 59219 & 1 & 972 & 18218 & & 1800 & & 40 \\
\hline 4702300015 & 6.9 & & 11144 & 0 & 85 & 1982 & & 550 & & 60 \\
\hline 4702300017 & 6.3 & & 48042 & & 1434 & 11411 & & 2750 & & 100 \\
\hline 4702300018 & 7.1 & & 7018 & 1 & 292 & 1101 & & 125 & & 100 \\
\hline 4702300019 & 4 & & 58583.3 & 0 & 1215 & 12431 & & 440 & & \\
\hline 4702300020 & 6.3 & & 51985 & 2 & 729 & 10811 & & 875 & & 160 \\
\hline 4702300021 & 6.3 & & 4258 & 1 & 49 & 701 & & 83 & & 25 \\
\hline 4702300023 & 4.9 & & 75916 & 1 & 1822 & 16040 & & 3000 & & \\
\hline 4702300030 & 6.3 & & 23754 & 6000 & 656 & 3368 & & 0 & & \\
\hline 4702300032 & 6.2 & & 2295 & & 109 & 4070 & & 0 & & \\
\hline 4703100016 & & & 1390 & 65 & 35 & 265 & & & & \\
\hline 4703500022 & & & 74332 & 3116 & 1976 & 22970 & & 580 & & 50 \\
\hline 4703500024 & & & 74320 & 3750 & 2492 & 20359 & 1082 & 2170 & & 12 \\
\hline 4703500041 & & & 37200 & 1900 & 1350 & 10450 & & 500 & & 880 \\
\hline 4703500053 & & & 69450 & 2900 & 3800 & 21900 & & 2000 & & 25 \\
\hline 4703500077 & & & 71650 & 5100 & 2500 & 23500 & & 1160 & & 120 \\
\hline 4703500094 & 6 & & 99068 & & 2673 & 27368 & & 0 & & \\
\hline 4703500103 & & & 70000 & 5300 & 3000 & 23100 & & 1025 & & 108 \\
\hline 4703500104 & 6.8 & & 29159 & & 948 & 5213 & & 0 & & \\
\hline
\end{tabular}




\begin{tabular}{|c|c|c|c|c|c|c|c|c|c|c|}
\hline Sample/API Number & $\mathrm{pH}$ & $\mathrm{Li}(\mathrm{mg} / \mathrm{L})$ & $\mathrm{Na}(\mathrm{mg} / \mathrm{L})$ & $\mathrm{K}(\mathrm{mg} / \mathrm{L})$ & $\mathrm{Mg}(\mathrm{mg} / \mathrm{L})$ & $\mathrm{Ca}(\mathrm{mg} / \mathrm{L})$ & $\mathrm{Sr}(\mathrm{mg} / \mathrm{L})$ & $\mathrm{Ba}(\mathrm{mg} / \mathrm{L})$ & $\mathrm{Mn}(\mathrm{mg} / \mathrm{L})$ & $\mathrm{Fe}(\mathrm{mg} / \mathrm{L})$ \\
\hline 4703500112 & & & 69700 & 4000 & 3000 & 23600 & & 42 & & 115 \\
\hline 4703500198 & & & 78076 & 194 & 2820 & 23600 & & 1100 & & 35 \\
\hline 4703500223 & & & 48000 & 2800 & 1815 & 14800 & & 440 & & 27 \\
\hline 4703500224 & & & 64600 & 6900 & 2130 & 19250 & & 250 & & 32 \\
\hline 4703500225 & 2.5 & & 87676 & & 4921 & 26266 & & 2 & & \\
\hline 4703500272 & 4.2 & & 78372 & & 3159 & 21052 & & 0 & & \\
\hline 4703500273 & 6.6 & & 82303 & & 2430 & 21654 & & 0 & & \\
\hline 4703500308 & & & 65370 & 4230 & 2400 & 20000 & & 1260 & & 45 \\
\hline 4703500312 & & & 72900 & 5600 & 2500 & 22150 & & 830 & & 60 \\
\hline 4703500332 & & & 64680 & 4350 & 2550 & 20900 & & 1260 & & 78 \\
\hline 4703500337 & & & 61000 & 3850 & 2400 & 19500 & & 1600 & & 45 \\
\hline 4703500381 & & & 72650 & 3750 & 2750 & 22100 & & 830 & & 38 \\
\hline 4703500398 & & & 71860 & 4100 & 2900 & 23500 & & 1235 & & 20 \\
\hline 4703500413 & 3.5 & & 52132 & & 2551 & 13032 & & 0 & & \\
\hline 4703500419 & 2.5 & & 100744 & & 3645 & 25864 & & 0 & & \\
\hline 4703500441 & & & 75372 & 2450 & 2950 & 22400 & & 618 & & 45 \\
\hline \multicolumn{11}{|l|}{4703500486} \\
\hline \multicolumn{11}{|l|}{4703500512} \\
\hline \multicolumn{11}{|l|}{4703500531} \\
\hline \multicolumn{11}{|l|}{4703500911} \\
\hline \multicolumn{11}{|l|}{4703502408} \\
\hline \multicolumn{11}{|l|}{4703502464} \\
\hline 4703900222 & & & 85700 & 2800 & 479 & 3920 & 1386 & 850 & & 5 \\
\hline 4703900226 & & & 69600 & 4850 & 2407 & 22600 & 1574 & 990 & & 75 \\
\hline 4703900269 & & & 81100 & 689 & 2580 & 4540 & 1331 & 1532 & & 26 \\
\hline 4703900321 & & & 98291 & 1520 & 2460 & 19170 & Trace & 1380 & & 3750 \\
\hline 4703900458 & & & 72391 & 3565 & 2740 & 22740 & & 750 & & 92 \\
\hline 4703900513 & & & 72982 & 3720 & 2380 & 23100 & & 1000 & & 131 \\
\hline 4703900696 & & & 67400 & 1400 & 4000 & 29000 & & 1200 & & 270 \\
\hline 4703900754 & & & 75270 & 2600 & 2200 & 24000 & & 1800 & & 270 \\
\hline 4703900771 & 3.2 & & 101531 & & 3523 & 27067 & & 0 & & \\
\hline 4703900926 & & & 70550 & 4070 & 2350 & 22500 & & 2075 & & 80 \\
\hline
\end{tabular}




\begin{tabular}{|c|c|c|c|c|c|c|c|c|c|c|}
\hline Sample/API Number & pH & $\mathrm{Li}(\mathrm{mg} / \mathrm{L})$ & $\mathrm{Na}(\mathrm{mg} / \mathrm{L})$ & $\mathrm{K}(\mathrm{mg} / \mathrm{L})$ & $\mathrm{Mg}(\mathrm{mg} / \mathrm{L})$ & $\mathrm{Ca}(\mathrm{mg} / \mathrm{L})$ & $\mathrm{Sr}(\mathrm{mg} / \mathrm{L})$ & $\mathrm{Ba}(\mathrm{mg} / \mathrm{L})$ & $\mathrm{Mn}(\mathrm{mg} / \mathrm{L})$ & $\mathrm{Fe}(\mathrm{mg} / \mathrm{L})$ \\
\hline \multicolumn{11}{|l|}{4703901352} \\
\hline \multicolumn{11}{|l|}{4703901533} \\
\hline \multicolumn{11}{|l|}{4703905269} \\
\hline 4705300260 & 9.4 & & 51428 & & 4374 & 24825 & & & & \\
\hline \multicolumn{11}{|l|}{4705500014} \\
\hline 4705700022 & 5 & & 53 & & 10 & 16 & & 3 & & 15 \\
\hline 4705900641 & 4.9 & & 13901 & 0 & 790 & 3509 & & 45 & & \\
\hline 4706100337 & & & 52200 & 2700 & 1860 & 24100 & & & & \\
\hline 4706100347 & & & 50000 & 2820 & 1880 & 23500 & & & & \\
\hline 4706900038 & 9.4 & & 51428 & & 4374 & 24825 & & 0 & & \\
\hline 4707100010 & 5.4 & & 51189 & 0 & 1312 & 15616 & & 4750 & & 850 \\
\hline 4707100012 & 7.4 & & 24598 & 1 & 267 & 4364 & & 500 & & \\
\hline 4707500011 & & & 3839 & & 486 & 6006 & & 110 & & \\
\hline 4707500014 & & & 48387 & & 9720 & 12412 & & & & \\
\hline 4707500025 & & & 83943 & & 2430 & 21622 & & 0 & & \\
\hline \multicolumn{11}{|l|}{4707500026} \\
\hline \multicolumn{11}{|l|}{4707500033} \\
\hline 4707500034 & & & 4386 & & 2673 & 7608 & & 0 & & \\
\hline 4707700013 & & & 25167 & & 243 & 8809 & & 4 & & \\
\hline 4707700021 & & & 40850 & & 486 & 6006 & & 0 & & \\
\hline 4707700025 & & & 8100 & 246 & 283 & 2340 & & & & \\
\hline 4707700058 & & & 78996 & & 2430 & 17618 & & 0 & & \\
\hline 4707700090 & 4.4 & & 101316 & & 1556 & 20532 & & & & \\
\hline 4707700141 & & & 3395 & & 1701 & 5606 & & 0 & & \\
\hline 4707700143 & & & 97473 & & 2430 & 20020 & & & & \\
\hline 4707700155 & & & 65338 & & 1118 & 10170 & & & & \\
\hline 4707700156 & & & 108470 & & 2430 & 20020 & & 0 & & \\
\hline 4707700158 & & & 40204 & & 632 & 9209 & & 0 & & \\
\hline 4707700162 & & & 102000 & & 2430 & 20020 & & 0 & & \\
\hline 4707700164 & & & 60320 & & 1701 & 15215 & & 0 & & \\
\hline 4707700166 & 6.4 & & 69218 & & 1701 & 24424 & & 3600 & & \\
\hline 4707700186 & & & 50200 & 3470 & 2530 & 33000 & & & & \\
\hline 4707700316 & 6.4 & & 69218 & & 1701 & 24424 & & 3600 & & \\
\hline
\end{tabular}




\begin{tabular}{|c|c|c|c|c|c|c|c|c|c|c|}
\hline Sample/API Number & $\mathrm{pH}$ & $\mathrm{Li}(\mathrm{mg} / \mathrm{L})$ & $\mathrm{Na}(\mathrm{mg} / \mathrm{L})$ & $\mathrm{K}(\mathrm{mg} / \mathrm{L})$ & $\mathrm{Mg}(\mathrm{mg} / \mathrm{L})$ & $\mathrm{Ca}(\mathrm{mg} / \mathrm{L})$ & $\mathrm{Sr}(\mathrm{mg} / \mathrm{L})$ & $\mathrm{Ba}(\mathrm{mg} / \mathrm{L})$ & $\mathrm{Mn}(\mathrm{mg} / \mathrm{L})$ & $\mathrm{Fe}(\mathrm{mg} / \mathrm{L})$ \\
\hline 4707900031 & & & 31655 & 700 & 1730 & 8600 & & 1650 & & \\
\hline 4707900204 & & & 68280 & 3400 & 3220 & 26140 & & 1700 & & 18 \\
\hline \multicolumn{11}{|l|}{4708100289} \\
\hline 4708300002 & & & 34000 & 4500 & 940 & 3200 & & 167 & & 6.7 \\
\hline \multicolumn{11}{|l|}{4708300096} \\
\hline 4708300097 & & & 26905 & & 729 & 9209 & & 610 & & \\
\hline 4708300118 & & & 28803 & & 4617 & 16416 & & 0 & & \\
\hline \multicolumn{11}{|l|}{4708300124} \\
\hline 4708300126 & & & 48755 & & 1701 & 19620 & & 0 & & \\
\hline 4708300612 & & & 62682 & & 3159 & 19219 & & 0 & & \\
\hline 4708300904 & 6 & & 43516 & & 3499 & 24024 & & & & 75 \\
\hline 4708700239 & & & 62000 & & 2550 & 17600 & & 1000 & & \\
\hline 4708700413 & & & 76330 & 4490 & 1372 & 24260 & & 100 & & 24.5 \\
\hline 4708700429 & & & 73850 & 4550 & 3200 & 22500 & & 2500 & & 84 \\
\hline \multicolumn{11}{|l|}{4708701200} \\
\hline \multicolumn{11}{|l|}{4708900005} \\
\hline 4709300002 & 4.2 & & 66631 & 1 & 2065 & 18018 & & 2250 & & \\
\hline 4709702852 & 3 & & 66053 & & 2066 & 27227 & & 1375 & & \\
\hline 4709900393 & & & 35340 & 830 & 1975 & 8060 & & & & 6.3 \\
\hline 4710500068 & & & 68100 & 3400 & 4110 & 27200 & 889 & 1550 & & 115 \\
\hline 4710500091 & & & 80000 & & 3200 & 2500 & & 1280 & & \\
\hline 4710500171 & & & 59450 & 4040 & 3770 & 29530 & & 1000 & & \\
\hline 4710500531 & 5.9 & & 75727 & & 4100 & 29160 & & & & \\
\hline \multicolumn{11}{|l|}{4710700306} \\
\hline \multicolumn{11}{|l|}{4710700336} \\
\hline 4710700346 & & & & & 1562 & 31120 & & & 4 & \\
\hline \multicolumn{11}{|l|}{4710700351} \\
\hline ED-82-37 & 5.63 & 105 & 24400 & 978 & 797 & 8930 & 4400 & 1510 & 6.2 & 458 \\
\hline ED-82-38 & 6.14 & 277 & 61300 & 2580 & 1580 & 17600 & 8930 & 3890 & 5.6 & 240 \\
\hline ED-82-39 & 5.65 & 315 & 79900 & 3180 & 2050 & 23800 & 13100 & 4370 & 5.7 & 207 \\
\hline ED-82-40 & 5.53 & 315 & 83300 & 3890 & 2390 & 28400 & 12800 & 3680 & 5.8 & 225 \\
\hline Maryland_GARCO_G41 & 3 & & & & 4980 & 74400 & & & & \\
\hline Maryland_WASCO_AC2 & 7 & & & & 29 & 77 & & & & \\
\hline
\end{tabular}




\begin{tabular}{|c|c|c|c|c|c|c|c|c|c|c|}
\hline Sample/API Number & $\mathrm{pH}$ & $\mathrm{Li}(\mathrm{mg} / \mathrm{L})$ & $\mathrm{Na}(\mathrm{mg} / \mathrm{L})$ & $\mathrm{K}(\mathrm{mg} / \mathrm{L})$ & $\mathrm{Mg}(\mathrm{mg} / \mathrm{L})$ & $\mathrm{Ca}(\mathrm{mg} / \mathrm{L})$ & $\mathrm{Sr}(\mathrm{mg} / \mathrm{L})$ & $\mathrm{Ba}(\mathrm{mg} / \mathrm{L})$ & $\mathrm{Mn}$ (mg/L) & $\mathrm{Fe}(\mathrm{mg} / \mathrm{L})$ \\
\hline Maryland-153 & & & 31500 & 1320 & 1040 & 10800 & & & & \\
\hline NewYork_1 & & & 254534 & 1815 & 1166 & 14797 & & & & \\
\hline NewYork_2 & & & 46214 & 1902 & 8750 & 74185 & & & & \\
\hline NewYork_3 & & & 59280 & 1848 & & 42700 & & & & \\
\hline NewYork_4 & & & 64000 & 1800 & 5290 & 44070 & & & & \\
\hline NewYork_5 & & & & & 6051 & 48320 & & & & \\
\hline OHIO_12 & & & 31486 & 1998 & 11785 & 43549 & & & & \\
\hline OHIO_18 & & & 21633 & 267 & 10016 & 29585 & 338 & & & \\
\hline OHIO_21 & & & 86422 & 2371 & 4078 & 25889 & 1802 & & & \\
\hline OHIO_243 & & & 51787 & & 6124 & 26945 & & & & \\
\hline OHIO_244 & & & 43409 & 3903 & 11207 & 48584 & & & & \\
\hline OHIO_25 & & & 33449 & 2024 & 11350 & 49011 & 957 & & & \\
\hline OHIO_2545 & & 167 & 73800 & 2260 & 4040 & 21000 & 2100 & & & \\
\hline OHIO_287 & & & 18491 & 1995 & 10589 & 36270 & 1383 & & & \\
\hline OHIO_29 & & & 35356 & 828 & 6690 & 16726 & trace & & & \\
\hline OHIO_3 & & & 31149 & 1884 & 11781 & 43407 & & & & \\
\hline OHIO_31 & & & 32422 & 1409 & 11653 & 43716 & 1281 & & & \\
\hline OHIO_32 & & & 50460 & 2097 & 6835 & 30844 & 345 & & & \\
\hline OHIO_34 & & & 31877 & 2706 & 11004 & 44556 & 1417 & & & \\
\hline OHIO_3477 & & 173 & 75000 & 2050 & 3790 & 19000 & 2060 & & & \\
\hline OHIO_36 & & & 27853 & 2091 & 10431 & 37946 & 1843 & & & \\
\hline OHIO_37 & & & 32898 & 2591 & 9872 & 41586 & 1160 & & & \\
\hline OHIO_38 & & & 17568 & 1003 & 6578 & 21619 & trace & & & \\
\hline OHIO_57 & & & 24351 & 1013 & 8978 & 24013 & 793 & & & \\
\hline OHIO_58 & & & 28689 & 2250 & 11442 & 41244 & 1645 & & & \\
\hline OHIO_65-88 & & 141 & 43300 & 3990 & 8720 & 38600 & 1730 & & & \\
\hline OHIO_709 & & 148 & 48200 & 4430 & 10200 & 43100 & 2130 & & & \\
\hline PENN_TULLY_1 & 6.5 & 187 & 42800 & 3970 & 8280 & 37300 & & & 1.7 & 3.9 \\
\hline PENN_TULLY_176 & 3.95 & & 78700 & 3400 & 2400 & 39300 & & & & \\
\hline PENN_TULLY_177 & 4.55 & & 74200 & 3700 & 2900 & 46800 & & & & \\
\hline PENN_TULLY_178 & 5 & & 78700 & 3500 & 2400 & 38500 & & & & \\
\hline PENN_TULLY_179 & 3.8 & & 47600 & 1576 & 1736 & 21400 & & & & \\
\hline PENN_TULLY_181 & 4.8 & & 58000 & 1968 & 2016 & 26200 & & & & \\
\hline
\end{tabular}




\begin{tabular}{|c|c|c|c|c|c|c|c|c|c|c|}
\hline Sample/API Number & $\mathrm{pH}$ & Li (mg/L) & $\mathrm{Na}(\mathrm{mg} / \mathrm{L})$ & $\mathrm{K}(\mathrm{mg} / \mathrm{L})$ & $\mathrm{Mg}(\mathrm{mg} / \mathrm{L})$ & $\mathrm{Ca}(\mathrm{mg} / \mathrm{L})$ & $\mathrm{Sr}(\mathrm{mg} / \mathrm{L})$ & $\mathrm{Ba}(\mathrm{mg} / \mathrm{L})$ & $\mathrm{Mn}(\mathrm{mg} / \mathrm{L})$ & $\mathrm{Fe}(\mathrm{mg} / \mathrm{L})$ \\
\hline PENN_TULLY_183 & 2.8 & & 54000 & 1920 & 520 & 38597 & & & & 1830 \\
\hline PENN_TULLY_183a & 4.5 & & 70000 & 2360 & 2182 & 48031 & & & & 2070 \\
\hline PENN_TULLY_185 & 4.85 & & 73400 & 3440 & 3040 & 44000 & & & & \\
\hline PENN_TULLY_185a & 4.9 & & 76000 & 3440 & 3040 & 44400 & & & & \\
\hline PENN_TULLY_186 & 3.55 & & 19000 & 2500 & 2500 & 36000 & & & & \\
\hline PENN_TULLY_187 & 3.15 & & 65300 & 2900 & 2400 & 33400 & & & & \\
\hline PENN_TULLY_189 & 4.9 & & 43600 & 1704 & 1856 & 24400 & & & & 112 \\
\hline PENN_TULLY_190 & 5.8 & & 55700 & 4900 & 3500 & 57400 & & & & \\
\hline PENN_TULLY_191 & 3.03 & & 74200 & 3300 & 2800 & 42500 & & & & \\
\hline PENN_TULLY_192 & 2.9 & & 55700 & 4900 & 3650 & 54100 & & & & \\
\hline PENN_TULLY_193 & 6.1 & & 47600 & 584 & 1240 & 10319 & & 1871 & & \\
\hline PENN_TULLY_193a & 4.3 & & 91000 & 1160 & 2267 & 18409 & & & & 226 \\
\hline PENN_TULLY_194 & 4.2 & & 71660 & 2320 & 1493 & 45169 & & & & 820 \\
\hline PENN_TULLY_195 & 3.6 & & 60000 & 1760 & 1252 & 36058 & & & & 2838 \\
\hline PENN_TULLY_196 & 4.4 & & 66000 & 2504 & 3360 & 38987 & & 640 & & 316 \\
\hline PENN_TULLY_197 & 4.1 & & 85000 & 1600 & 1944 & 41438 & & & & 389 \\
\hline PENN_TULLY_198 & 6.5 & & 45600 & 576 & 1075 & 5920 & & 921 & & \\
\hline PENN_TULLY_199 & 3.9 & & 69600 & 2304 & 5019 & 4967 & & & & 294 \\
\hline PENN_TULLY_200 & 5.8 & & 104070 & 2072 & 1250 & 13413 & & & & 379 \\
\hline PENN_TULLY_201 & 8.1 & & 195 & 6 & 29 & & & & & \\
\hline PENN_TULLY_203 & 3.7 & & 93000 & 1040 & 971 & 11193 & & & & 220 \\
\hline PENN_TULLY_204 & 3.5 & & 74400 & 3344 & 3840 & 42000 & & & & 16.5 \\
\hline PENN_TULLY_205 & 5.1 & & 64000 & 2000 & 8000 & 36000 & & & & \\
\hline PENN_TULLY_209 & 5.15 & & 34200 & 940 & 1020 & 12400 & & & & \\
\hline PENN_TULLY_210 & 3.1 & & 92000 & 2560 & 2000 & 24400 & & & & \\
\hline PENN_TULLY_211 & 3.2 & & 47400 & 1360 & 1296 & 13200 & & & & \\
\hline PENN_TULLY_212 & 2.4 & & 94400 & 2440 & 1760 & 20000 & & & & \\
\hline PENN_TULLY_213 & 4.95 & & 43000 & 1500 & 1600 & 19200 & & & & \\
\hline PENN_TULLY_214 & 4.2 & & 66000 & 2400 & 1920 & 25000 & & & & \\
\hline PENN_TULLY_215 & 3.65 & & 76000 & 2460 & 1760 & 26800 & & & & \\
\hline PENN_TULLY_216 & 3.55 & & 57000 & 2040 & 1020 & 24600 & & & & \\
\hline PENN_TULLY_217 & 3.2 & & 15520 & 34 & 1640 & 5880 & & & & \\
\hline PENN_TULLY_217a & 3.9 & & 34000 & 1160 & 1000 & 10408 & & & & \\
\hline
\end{tabular}




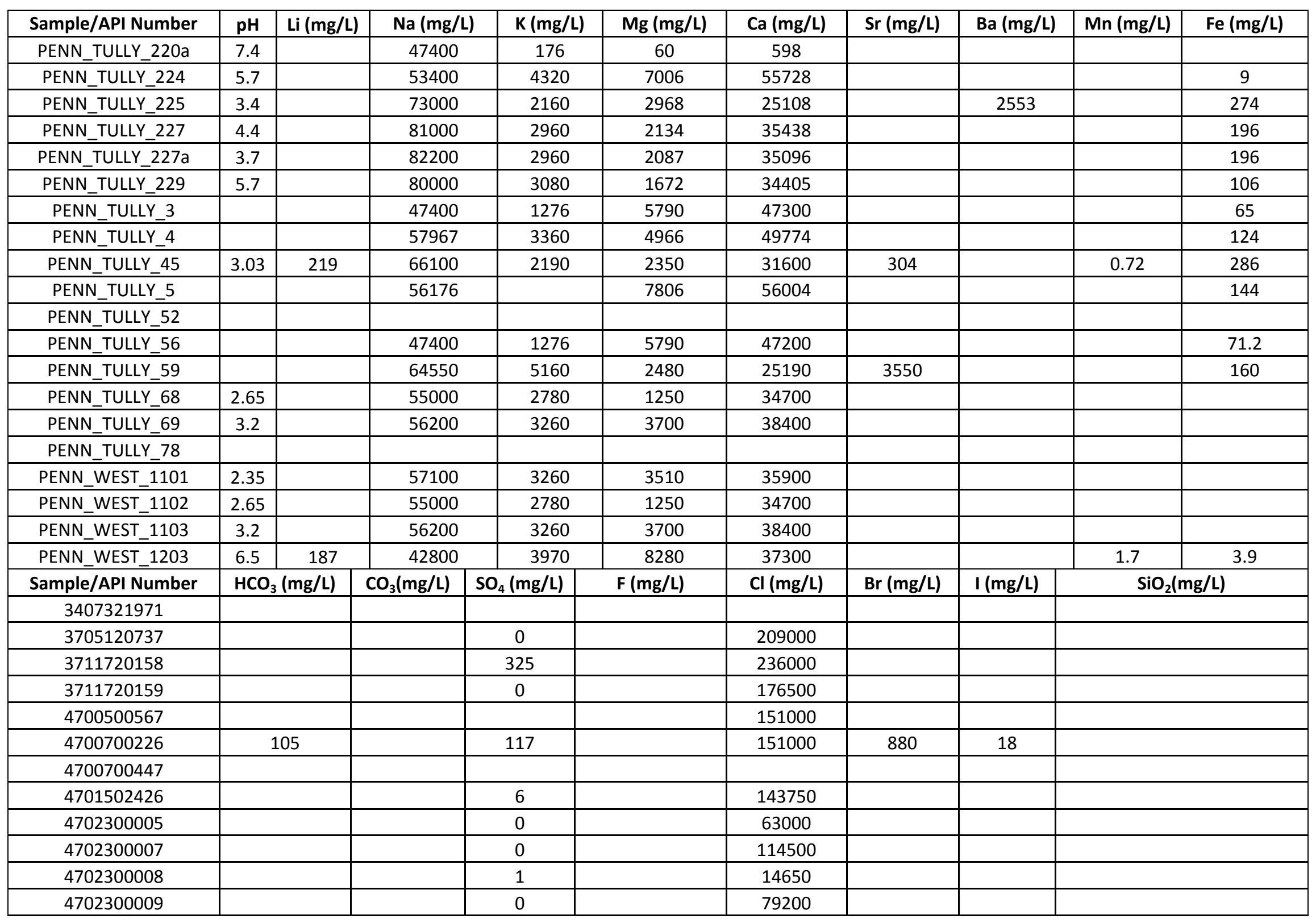




\begin{tabular}{|c|c|c|c|c|c|c|c|c|}
\hline Sample/API Number & $\mathrm{HCO}_{3}(\mathrm{mg} / \mathrm{L})$ & $\mathrm{CO}_{3}(\mathrm{mg} / \mathrm{L})$ & $\mathrm{SO}_{4}(\mathrm{mg} / \mathrm{L})$ & $F(\mathrm{mg} / \mathrm{L})$ & $\mathrm{Cl}(\mathrm{mg} / \mathrm{L})$ & $\mathrm{Br}(\mathrm{mg} / \mathrm{L})$ & $\mathrm{I}(\mathrm{mg} / \mathrm{L})$ & $\mathrm{SiO}_{2}(\mathrm{mg} / \mathrm{L})$ \\
\hline 4702300010 & & & 0 & & 125000 & & & \\
\hline 4702300011 & & & 0 & & 55600 & & & \\
\hline 4702300012 & & & 1250 & & 68000 & & & \\
\hline 4702300013 & & & 0 & & 121500 & & & \\
\hline 4702300014 & & & 0 & & 127500 & & & \\
\hline 4702300015 & & & 0 & & 21250 & & & \\
\hline 4702300017 & & & 0 & & 100000 & & & \\
\hline 4702300018 & & & 0 & & 13700 & & & \\
\hline 4702300019 & & & 0 & & 116250 & & & \\
\hline 4702300020 & & & 0 & & 102000 & & & \\
\hline 4702300021 & & & 0 & & 8000 & & & \\
\hline 4702300023 & & & 0 & & 152500 & & & \\
\hline 4702300030 & & & 0 & & 50000 & & & \\
\hline 4702300032 & & & 120 & & 11000 & & & \\
\hline 4703100016 & & & & & 27900 & & & \\
\hline 4703500022 & & & 154 & & 163500 & 580 & 16 & \\
\hline 4703500024 & 3 & & 111 & & 161300 & 2170 & 23 & \\
\hline 4703500041 & & & 110 & & 85800 & 500 & 8 & \\
\hline 4703500053 & & & 79 & & 159000 & 2000 & 0.8 & \\
\hline 4703500077 & 31 & & 76 & & 164000 & 1160 & 9 & \\
\hline 4703500094 & & & 18 & & 209250 & & & \\
\hline 4703500103 & 90 & & 86 & & 162000 & 1025 & 4 & \\
\hline 4703500104 & & & 22 & & 57000 & & & \\
\hline 4703500112 & 118 & & 83 & & 161600 & 42 & 18 & \\
\hline 4703500198 & 35 & & 41 & & 170000 & 1100 & 20 & \\
\hline 4703500223 & 15 & & 69 & & 107270 & 440 & 4 & \\
\hline 4703500224 & & & 52 & & 146000 & 250 & 17 & \\
\hline 4703500225 & & & 18 & & 196250 & & & \\
\hline 4703500272 & & & 34 & & 167500 & & & \\
\hline 4703500273 & & & 60 & & 172500 & & & \\
\hline 4703500308 & & & 65 & & 146400 & 1260 & 23 & \\
\hline 4703500312 & 77 & & 58 & & 163500 & 830 & 20 & \\
\hline 4703500332 & & & 49 & & 147500 & 1260 & 23 & \\
\hline
\end{tabular}




\begin{tabular}{|c|c|c|c|c|c|c|c|c|}
\hline Sample/API Number & $\mathrm{HCO}_{3}(\mathrm{mg} / \mathrm{L})$ & $\mathrm{CO}_{3}(\mathrm{mg} / \mathrm{L})$ & $\mathrm{SO}_{4}(\mathrm{mg} / \mathrm{L})$ & $F(\mathrm{mg} / \mathrm{L})$ & $\mathrm{Cl}(\mathrm{mg} / \mathrm{L})$ & $\mathrm{Br}(\mathrm{mg} / \mathrm{L})$ & $\mathrm{I}(\mathrm{mg} / \mathrm{L})$ & $\mathrm{SiO}_{2}(\mathrm{mg} / \mathrm{L})$ \\
\hline 4703500337 & & & 62 & & 138300 & 1600 & 11 & \\
\hline 4703500381 & & & 89 & & 162100 & 830 & 2 & \\
\hline 4703500398 & & & 60 & & 164000 & 1235 & 8 & \\
\hline 4703500413 & & & 30 & & 111000 & & & \\
\hline 4703500419 & & & 18 & & 212000 & & & \\
\hline 4703500441 & 5 & & 72 & & 166400 & 618 & 11 & \\
\hline \multicolumn{9}{|l|}{4703500486} \\
\hline \multicolumn{9}{|l|}{4703500512} \\
\hline \multicolumn{9}{|l|}{4703500531} \\
\hline \multicolumn{9}{|l|}{4703500911} \\
\hline \multicolumn{9}{|l|}{4703502408} \\
\hline \multicolumn{9}{|l|}{4703502464} \\
\hline 4703900222 & 133 & & 113 & & 143600 & 850 & 3.4 & \\
\hline 4703900226 & 100 & & 68 & & 159900 & 990 & Trace & \\
\hline 4703900269 & 266 & & 62 & & 141400 & 1532 & 34 & \\
\hline 4703900321 & 120 & & 46 & & 144800 & 1380 & 14 & \\
\hline 4703900458 & & & 77 & & 161900 & 750 & 25 & \\
\hline 4703900513 & & & 62 & & 163300 & 1000 & 21 & \\
\hline 4703900696 & 80 & & 75 & & 150200 & 1200 & Trace & \\
\hline 4703900754 & 140 & & 93 & & 166700 & 1800 & 20 & \\
\hline 4703900771 & & & 12 & & 215000 & & & \\
\hline 4703900926 & 140 & & 45 & & 158100 & 2075 & 13 & \\
\hline \multicolumn{9}{|l|}{4703901352} \\
\hline \multicolumn{9}{|l|}{4703901533} \\
\hline \multicolumn{9}{|l|}{4703905269} \\
\hline 4705300260 & & & 220 & & 136000 & & & \\
\hline \multicolumn{9}{|l|}{4705500014} \\
\hline 4705700022 & & & 0 & & 140 & & & \\
\hline 4705900641 & & & 0 & & 30000 & & & \\
\hline 4706100337 & & & 0 & & 199000 & & & \\
\hline 4706100347 & & & 0 & & 193000 & & & \\
\hline 4706900038 & & & 220 & & 136000 & & & \\
\hline 4707100010 & & & 0 & & 113000 & & & \\
\hline
\end{tabular}




\begin{tabular}{|c|c|c|c|c|c|c|c|c|}
\hline Sample/API Number & $\mathrm{HCO}_{3}(\mathrm{mg} / \mathrm{L})$ & $\mathrm{CO}_{3}(\mathrm{mg} / \mathrm{L})$ & $\mathrm{SO}_{4}(\mathrm{mg} / \mathrm{L})$ & $F(\mathrm{mg} / \mathrm{L})$ & $\mathrm{Cl}(\mathrm{mg} / \mathrm{L})$ & $\mathrm{Br}(\mathrm{mg} / \mathrm{L})$ & $\mathrm{I}(\mathrm{mg} / \mathrm{L})$ & $\mathrm{SiO}_{2}(\mathrm{mg} / \mathrm{L})$ \\
\hline 4707100012 & & & 0 & & 46750 & & & \\
\hline 4707500011 & & & 0 & & 18000 & & & \\
\hline 4707500014 & & & 0 & & 125000 & & & \\
\hline 4707500025 & & & 18 & & 175000 & & & \\
\hline \multicolumn{9}{|l|}{4707500026} \\
\hline \multicolumn{9}{|l|}{4707500033} \\
\hline 4707500034 & & & 70 & & 28000 & & & \\
\hline 4707700013 & & & 125 & & 55000 & & & \\
\hline 4707700021 & & & 170 & & 75000 & & & \\
\hline 4707700025 & & & & & 16600 & & & \\
\hline 4707700058 & & & 370 & & 160000 & & & \\
\hline 4707700090 & 0 & & 635 & & 197915 & & & \\
\hline 4707700141 & & & 185 & & 20000 & & & \\
\hline 4707700143 & & & 100 & & 193000 & & & \\
\hline 4707700155 & & & & & 122000 & & & \\
\hline 4707700156 & & & 40 & & 210000 & & & \\
\hline 4707700158 & & & 325 & & 80000 & & & \\
\hline 4707700162 & & & 78 & & 200000 & & & \\
\hline 4707700164 & & & 82 & & 125000 & & & \\
\hline 4707700166 & & & 0 & & 157000 & & & \\
\hline 4707700186 & & & 0 & & 203000 & & & \\
\hline 4707700316 & & & 0 & & 157000 & & & \\
\hline 4707900031 & & & & & 69700 & & & \\
\hline 4707900204 & 23 & & 53 & & 163200 & 1700 & 5 & \\
\hline \multicolumn{9}{|l|}{4708100289} \\
\hline 4708300002 & 122 & & 900 & & 64000 & 167 & 5.7 & \\
\hline \multicolumn{9}{|l|}{4708300096} \\
\hline 4708300097 & & & 0 & & 60000 & & & \\
\hline 4708300118 & & & 40 & & 87000 & & & \\
\hline \multicolumn{9}{|l|}{4708300124} \\
\hline 4708300126 & & & 37 & & 115000 & & & \\
\hline 4708300612 & & & 70 & & 140000 & & & \\
\hline 4708300904 & & & & & 120000 & & & \\
\hline
\end{tabular}




\begin{tabular}{|c|c|c|c|c|c|c|c|c|}
\hline Sample/API Number & $\mathrm{HCO}_{3}(\mathrm{mg} / \mathrm{L})$ & $\mathrm{CO}_{3}(\mathrm{mg} / \mathrm{L})$ & $\mathrm{SO}_{4}(\mathrm{mg} / \mathrm{L})$ & $F(\mathrm{mg} / \mathrm{L})$ & $\mathrm{Cl}(\mathrm{mg} / \mathrm{L})$ & $\mathrm{Br}(\mathrm{mg} / \mathrm{L})$ & $\mathrm{I}(\mathrm{mg} / \mathrm{L})$ & $\mathrm{SiO}_{2}(\mathrm{mg} / \mathrm{L})$ \\
\hline 4708700239 & 34 & & 1587 & & 135100 & 642 & 5 & \\
\hline 4708700413 & 200 & & 89 & & 168300 & 100 & 20 & \\
\hline 4708700429 & & & 41 & & 166000 & 2500 & 13 & \\
\hline \multicolumn{9}{|l|}{4708701200} \\
\hline \multicolumn{9}{|l|}{4708900005} \\
\hline 4709300002 & & & 0 & & 142000 & & & \\
\hline 4709702852 & & & 0 & & 157000 & & & \\
\hline 4709900393 & 30 & & 8 & & 75310 & & & \\
\hline 4710500068 & 113 & & 119 & & 169200 & 1245 & 2.7 & \\
\hline 4710500091 & & & & & 172000 & 1280 & 18 & \\
\hline 4710500171 & 115 & & 86 & & 158000 & 1000 & 8.3 & \\
\hline 4710500531 & 61 & & 180 & & 182500 & & & \\
\hline \multicolumn{9}{|l|}{4710700306} \\
\hline \multicolumn{9}{|l|}{4710700336} \\
\hline 4710700346 & & & & & 202400 & & & \\
\hline \multicolumn{9}{|l|}{4710700351} \\
\hline ED-82-37 & n.d. & & 2.2 & tr. & 58900 & 349 & 16 & \\
\hline ED-82-38 & 194 & & n.d. & tr. & 133000 & 763 & 35 & \\
\hline ED-82-39 & 122 & & 1 & tr. & 174000 & 1010 & 52 & \\
\hline ED-82-40 & 99 & & n.d. & tr. & 207000 & 1130 & 44 & \\
\hline Maryland_GARCO_G41 & & & & & 226000 & & & \\
\hline Maryland_WASCO_AC2 & & & & & 7 & & & \\
\hline Maryland-153 & & & & & 86300 & & & \\
\hline NewYork_1 & & & & & 153202 & & & \\
\hline NewYork_2 & & & & & 173254 & & & \\
\hline NewYork_3 & & & & & 209800 & & & \\
\hline NewYork_4 & & & & & 200730 & & & \\
\hline NewYork_5 & & & & & 206900 & & & \\
\hline OHIO_12 & 152 & & 228 & & 162210 & 1265 & & 101 \\
\hline OHIO_18 & 231 & & 213 & & 114247 & 1228 & & 53 \\
\hline OHIO_21 & 16 & & 95 & & 193105 & 2086 & & 47 \\
\hline OHIO_243 & & & 555 & & 144339 & 1340 & & \\
\hline OHIO_244 & & & 207 & & 188390 & & & \\
\hline
\end{tabular}




\begin{tabular}{|c|c|c|c|c|c|c|c|c|}
\hline Sample/API Number & $\mathrm{HCO}_{3}(\mathrm{mg} / \mathrm{L})$ & $\mathrm{CO}_{3}(\mathrm{mg} / \mathrm{L})$ & $\mathrm{SO}_{4}(\mathrm{mg} / \mathrm{L})$ & $F(\mathrm{mg} / \mathrm{L})$ & $\mathrm{Cl}(\mathrm{mg} / \mathrm{L})$ & $\mathrm{Br}(\mathrm{mg} / \mathrm{L})$ & $\mathrm{I}(\mathrm{mg} / \mathrm{L})$ & $\mathrm{SiO}_{2}(\mathrm{mg} / \mathrm{L})$ \\
\hline OHIO_25 & 219 & & 219 & & 174137 & 2024 & & 55 \\
\hline OHIO_2545 & & & & & 174000 & 1520 & 26 & \\
\hline OHIO_287 & & & 217 & & 126768 & 1324 & & 20 \\
\hline OHIO_29 & 116 & & 778 & & 104460 & 613 & & 5 \\
\hline OHIO_3 & 176 & & 352 & & 160592 & 1181 & & 100 \\
\hline OHIO_31 & 128 & & 359 & & 164519 & 589 & & 5 \\
\hline OHIO_32 & 5 & & 469 & & 154984 & 592 & & 10 \\
\hline OHIO_34 & 129 & & 232 & & 163846 & 1881 & & 8 \\
\hline OHIO_3477 & & & & & 169000 & 1540 & 27 & \\
\hline OHIO_36 & 2 & & 337 & & 142591 & 1619 & & 7 \\
\hline OHIO_37 & 25 & & 123 & & 156767 & 1654 & & 12 \\
\hline OHIO_38 & 53 & & 548 & & 85341 & 936 & & 3 \\
\hline OHIO_57 & 169 & & 338 & & 108017 & 793 & & 51 \\
\hline OHIO_58 & 97 & & 121 & & 155372 & 847 & & 48 \\
\hline OHIO_65-88 & & & & & 174000 & 1870 & 17 & \\
\hline OHIO_709 & & & & & 195000 & 1900 & 19 & \\
\hline PENN_TULLY_1 & & & 528 & 2.3 & 157000 & 10600 & 32 & 5020 \\
\hline PENN_TULLY_176 & & & 10 & & 200602 & 1860 & & \\
\hline PENN_TULLY_177 & & & 20 & & 208040 & 2240 & & \\
\hline PENN_TULLY_178 & & & 10 & & 198947 & 1580 & 5 & \\
\hline PENN_TULLY_179 & & & & & 117301 & 1032 & & \\
\hline PENN_TULLY_181 & & & & & 142265 & 1095 & 5 & \\
\hline PENN_TULLY_183 & & & & & 158313 & & & \\
\hline PENN_TULLY_183a & & & & & 204925 & 1020 & 21 & \\
\hline PENN_TULLY_185 & & & & & 202560 & 1050 & 8.6 & \\
\hline PENN_TULLY_185a & & & & & 207277 & 1056 & 9 & \\
\hline PENN_TULLY_186 & 34 & & 100 & & 148062 & 1500 & 8 & \\
\hline PENN_TULLY_187 & 16 & & 100 & & 168666 & 1520 & 7 & \\
\hline PENN_TULLY_189 & 28 & & & & 117151 & 930 & 4 & \\
\hline PENN_TULLY_190 & 76 & & 20 & & 201120 & 2120 & 7 & \\
\hline PENN_TULLY_191 & & & 100 & & 200059 & 1460 & 10 & \\
\hline PENN_TULLY_192 & 33 & & 100 & & 196389 & 640 & 19 & \\
\hline PENN_TULLY_193 & 14 & & & & 96421 & 980 & 54 & \\
\hline
\end{tabular}




\begin{tabular}{|c|c|c|c|c|c|c|c|c|}
\hline Sample/API Number & $\mathrm{HCO}_{3}(\mathrm{mg} / \mathrm{L})$ & $\mathrm{CO}_{3}(\mathrm{mg} / \mathrm{L})$ & $\mathrm{SO}_{4}(\mathrm{mg} / \mathrm{L})$ & $F(\mathrm{mg} / \mathrm{L})$ & $\mathrm{Cl}(\mathrm{mg} / \mathrm{L})$ & $\mathrm{Br}(\mathrm{mg} / \mathrm{L})$ & $\mathrm{I}(\mathrm{mg} / \mathrm{L})$ & $\mathrm{SiO}_{2}(\mathrm{mg} / \mathrm{L})$ \\
\hline PENN_TULLY_193a & & & & & 179028 & 4050 & 105 & \\
\hline PENN_TULLY_194 & & & & & 197701 & 1440 & 10 & \\
\hline PENN_TULLY_195 & & & & & 166674 & 690 & & \\
\hline PENN_TULLY_196 & & & & & 183185 & 850 & 12 & \\
\hline PENN_TULLY_197 & & & & & 193986 & 780 & & \\
\hline PENN_TULLY_198 & & & & & 84476 & 960 & 45 & \\
\hline PENN_TULLY_199 & & & & & 196249 & 1500 & 13 & \\
\hline PENN_TULLY_200 & 19 & & 160 & & 190528 & 1260 & 18 & \\
\hline PENN_TULLY_201 & 173 & & & & 289 & & & \\
\hline PENN_TULLY_203 & & & & & 166847 & 810 & & \\
\hline PENN_TULLY_204 & & & & & 202181 & 1740 & 11 & \\
\hline PENN_TULLY_205 & 10 & & 1 & & 134000 & & & \\
\hline PENN_TULLY_209 & & & 20 & & 78479 & 32 & & \\
\hline PENN_TULLY_210 & & & & & 192880 & 672 & 36 & \\
\hline PENN_TULLY_211 & & & & & 101226 & 525 & & \\
\hline PENN_TULLY_212 & & & & & 187479 & 1260 & 32 & \\
\hline PENN_TULLY_213 & & & & & 106185 & 276 & & \\
\hline PENN_TULLY_214 & & & & & 153452 & 732 & 25 & \\
\hline PENN_TULLY_215 & & & & & 172490 & 900 & 44 & \\
\hline PENN_TULLY_216 & & & & & 136101 & 330 & 4 & \\
\hline PENN_TULLY_217 & & & & & 391540 & & & \\
\hline PENN_TULLY_217a & & & & & 76636 & 384 & & \\
\hline PENN_TULLY_220a & 329 & & 231 & & 74027 & 200 & & \\
\hline PENN_TULLY_224 & & & & & 205023 & 660 & 16 & \\
\hline PENN_TULLY_225 & & & & & 168779 & 1100 & 22 & \\
\hline PENN_TULLY_227 & & & & & 194171 & 1020 & 30 & \\
\hline PENN_TULLY_227a & & & & & 197627 & 780 & 40 & \\
\hline PENN_TULLY_229 & & & & & 190808 & 2760 & 40 & \\
\hline PENN_TULLY_3 & & & 2 & & 172500 & 70 & 1 & \\
\hline PENN_TULLY_4 & & & 194 & & 198790 & & & \\
\hline PENN_TULLY_45 & & & & 21 & 166000 & 1060 & 13 & 23 \\
\hline PENN_TULLY_5 & & & 166 & & 208078 & & & \\
\hline PENN_TULLY_52 & & & & & 212700 & & & \\
\hline
\end{tabular}




\begin{tabular}{|c|c|c|c|c|c|c|c|c|}
\hline Sample/API Number & $\mathrm{HCO}_{3}(\mathrm{mg} / \mathrm{L})$ & $\mathrm{CO}_{3}(\mathrm{mg} / \mathrm{L})$ & $\mathrm{SO}_{4}(\mathrm{mg} / \mathrm{L})$ & $\mathrm{F}(\mathrm{mg} / \mathrm{L})$ & $\mathrm{Cl}(\mathrm{mg} / \mathrm{L})$ & $\mathrm{Br}(\mathrm{mg} / \mathrm{L})$ & $\mathrm{I}(\mathrm{mg} / \mathrm{L})$ & $\mathrm{SiO}_{2}(\mathrm{mg} / \mathrm{L})$ \\
\hline PENN_TULLY_56 & & & 2 & & 172300 & 580 & & \\
\hline PENN_TULLY_59 & & & 50 & & 161800 & 700 & & \\
\hline PENN_TULLY_68 & & & & & 154000 & 1260 & 56 & \\
\hline PENN_TULLY_69 & & & & & 170000 & 1400 & 23 & \\
\hline PENN_TULLY_78 & & & & & 185000 & & & \\
\hline PENN_WEST_1101 & & & & & 169000 & 1440 & 8.6 & \\
\hline PENN_WEST_1102 & & & & & 154000 & 1260 & 5.6 & \\
\hline PENN_WEST_1103 & & & & & 170000 & 1400 & 23 & \\
\hline PENN_WEST_1203 & 176 & & 528 & 2.3 & 161000 & 1770 & 32 & \\
\hline
\end{tabular}

Source: $\quad$ A-Ohio Stat Division of Natural Resources website http://www.dnr.state.oh.us

B-West Virginia Geologic and Economic Survey website http://www.wvgs.wvnet.edu

C-Chesapeake Energy

D—Kelley, D.R., et al., 1973

E-Poth, C.W., 1962

F-Dresel, P.E., 1985

G-Stout, W., et al., 1932

H-Hoskins, H.A., 1947

I-Price, P.H., et al., 1937

J-Lloyd O.B. and Reid, M.S., 1990

$\mathrm{K}$-NiSource Incorporated.

L-NatCarb website http://www.natcarb.org

M-Woll, R.S., 1978

*--New study data

All data used in this study are available on the West Virginia GIS Technical Center website http://wvgis.wvu.edu. 
Appendix IV

Oriskany Sandstone Density Data. 
Oriskany Sandstone density data.

\begin{tabular}{|c|c|c|c|c|c|c|c|}
\hline Sample/API Number & Horizon & Latitude & Longitude & GL Elevation (m) & Depth/Top (m) & TDS Calculated (mg/L) & Density $\left(\mathrm{kg} / \mathrm{m}^{3}\right)$ \\
\hline 3711720158 & Oriskany & 41.76024 & -76.99193 & 522 & 2038 & 385500 & 1308.0 \\
\hline 3711720159 & Oriskany & 41.45374 & -76.59301 & 523 & 2039 & 277375 & 1207.5 \\
\hline 4700700226 & Oriskany & 38.68439 & -80.82756 & 352 & 1914 & 246819 & 1182.8 \\
\hline 4700700447 & Oriskany & 38.79923 & -80.55487 & 269 & 2101 & 80000 & 1045.6 \\
\hline 4701502426 & Oriskany & 38.38474 & -81.25295 & 436 & 1900 & 222949 & 1162.3 \\
\hline 4702300005 & Oriskany & 39.04240 & -79.28571 & 912 & 2525 & 102548 & 1058.5 \\
\hline 4702300007 & Oriskany & 38.95471 & -79.32992 & 825 & 2563 & 187404 & 1124.5 \\
\hline 4702300008 & Oriskany & 39.12748 & -79.24653 & 796 & 2448 & 23908 & 1000.7 \\
\hline 4702300009 & Oriskany & 38.96604 & -79.32082 & 834 & 2508 & 128344 & 1078.3 \\
\hline 4702300010 & Oriskany & 38.14823 & -79.23740 & 805 & 2504 & 204038 & 1138.7 \\
\hline 4702300011 & Oriskany & 39.18613 & -79.21765 & 879 & 2716 & 90079 & 1046.9 \\
\hline 4702300012 & Oriskany & 39.08072 & -79.26823 & 815 & 2524 & 110545 & 1064.6 \\
\hline 4702300013 & Oriskany & 39.09597 & -79.27809 & 904 & 2650 & 197705 & 1131.6 \\
\hline 4702300014 & Oriskany & 39.11528 & -79.25558 & 645 & 2319 & 207709 & 1144.3 \\
\hline 4702300015 & Oriskany & 39.05692 & -79.27511 & 765 & 2423 & 35011 & 1009.3 \\
\hline 4702300017 & Oriskany & 39.02178 & -79.29464 & 868 & 2582 & 163637 & 1105.4 \\
\hline 4702300018 & Oriskany & 39.06824 & -79.26191 & 698 & 2376 & 22236 & 1000.5 \\
\hline 4702300019 & Oriskany & 39.26119 & -79.18189 & 959 & 2973 & 188919.3 & 1121.0 \\
\hline 4702300020 & Oriskany & 39.07332 & -79.29409 & 1055 & 2830 & 166400 & 1104.7 \\
\hline 4702300021 & Oriskany & 39.07782 & -79.25428 & 611 & 2381 & 13091 & 993.8 \\
\hline 4702300023 & Oriskany & 39.10715 & -79.26953 & 829 & 2557 & 249278 & 1175.9 \\
\hline 4702300030 & Oriskany & 39.28557 & -79.15300 & 814 & 2833 & 83778 & 1041.2 \\
\hline 4702300032 & Oriskany & 39.09612 & -79.24944 & 596 & 2359 & 17594 & 998.5 \\
\hline 4703500022 & Oriskany & 38.69528 & -81.54256 & 296 & 1677 & 266694 & 1203.0 \\
\hline 4703500024 & Oriskany & 38.65926 & -81.54996 & 300 & 1659 & 266019 & 1203.1 \\
\hline 4703500041 & Oriskany & 38.59932 & -81.63977 & 200 & 1512 & 138199 & 1096.9 \\
\hline
\end{tabular}




\begin{tabular}{|c|c|c|c|c|c|c|c|}
\hline Sample/API Number & Horizon & Latitude & Longitude & GL Elevation (m) & Depth/Top (m) & TDS Calculated (mg/L) & Density $\left(\mathrm{kg} / \mathrm{m}^{3}\right)$ \\
\hline 4703500053 & Oriskany & 38.57157 & -81.59830 & 254 & 1555 & 259914 & 1199.0 \\
\hline 4703500077 & Oriskany & 38.57535 & -81.64983 & 288 & 1592 & 268146 & 1205.7 \\
\hline 4703500094 & Oriskany & 38.60634 & -81.65371 & 213 & 1509 & 338377 & 1272.0 \\
\hline 4703500103 & Oriskany & 38.94282 & -81.58816 & 204 & 1546 & 264713 & 1203.3 \\
\hline 4703500104 & Oriskany & 38.60925 & -81.62882 & 276 & 1586 & 92342 & 1059.9 \\
\hline 4703500112 & Oriskany & 38.95341 & -81.62567 & 211 & 1523 & 262276 & 1201.1 \\
\hline 4703500198 & Oriskany & 38.86180 & -81.61973 & 211 & 1644 & 275968 & 1212.0 \\
\hline 4703500223 & Oriskany & 38.82898 & -81.61559 & 195 & 1532 & 175678 & 1126.8 \\
\hline 4703500224 & Oriskany & 38.61543 & -81.58049 & 208 & 1543 & 239231 & 1180.8 \\
\hline 4703500225 & Oriskany & 38.61878 & -81.64038 & 234 & 1536 & 315133 & 1249.3 \\
\hline 4703500272 & Oriskany & 38.74753 & -81.63530 & 256 & 1579 & 270117 & 1207.5 \\
\hline 4703500273 & Oriskany & 38.74394 & -81.64003 & 269 & 1589 & 278947 & 1215.4 \\
\hline 4703500308 & Oriskany & 38.91959 & -81.60821 & 235 & 1579 & 239793 & 1180.7 \\
\hline 4703500312 & Oriskany & 38.79386 & -81.61874 & 213 & 1549 & 267695 & 1206.0 \\
\hline 4703500332 & Oriskany & 38.86413 & -81.59392 & 213 & 1597 & 241390 & 1182.1 \\
\hline 4703500337 & Oriskany & 38.91623 & -81.61323 & 285 & 1628 & 226768 & 1168.7 \\
\hline 4703500381 & Oriskany & 38.63067 & -81.64995 & 248 & 1561 & 264309 & 1203.0 \\
\hline 4703500398 & Oriskany & 38.78094 & -81.62115 & 273 & 1610 & 267683 & 1205.3 \\
\hline 4703500413 & Oriskany & 38.77699 & -81.62970 & 303 & 1625 & 178745 & 1128.2 \\
\hline 4703500419 & Oriskany & 38.76065 & -81.64656 & 190 & 1503 & 342271 & 1275.7 \\
\hline 4703500441 & Oriskany & 38.75161 & -81.62059 & 253 & 1590 & 270323 & 1207.7 \\
\hline 4703900222 & Oriskany & 38.27818 & -81.50221 & 345 & 1550 & 238989 & 1180.6 \\
\hline 4703900226 & Oriskany & 38.43875 & -81.35657 & 382 & 1761 & 262164 & 1198.3 \\
\hline 4703900269 & Oriskany & 38.26830 & -81.50828 & 405 & 1600 & 233580 & 1175.3 \\
\hline 4703900321 & Oriskany & 38.44919 & -81.57264 & 280 & 1523 & 271551 & 1209.4 \\
\hline 4703900458 & Oriskany & 38.44615 & -81.58850 & 305 & 1561 & 264280 & 1202.9 \\
\hline 4703900513 & Oriskany & 38.45065 & -81.59200 & 315 & 1569 & 266696 & 1204.4 \\
\hline 4703900696 & Oriskany & 38.52934 & -81.66645 & 261 & 1539 & 253625 & 1193.5 \\
\hline
\end{tabular}




\begin{tabular}{|c|c|c|c|c|c|c|c|}
\hline Sample/API Number & Horizon & Latitude & Longitude & GL Elevation (m) & Depth/Top (m) & TDS Calculated (mg/L) & Density $\left(\mathrm{kg} / \mathrm{m}^{3}\right)$ \\
\hline 4703900754 & Oriskany & 38.47315 & -81.44838 & 223 & 1589 & 273093 & 1210.1 \\
\hline 4703900771 & Oriskany & 38.56897 & -81.64680 & 232 & 1537 & 347133 & 1279.5 \\
\hline 4703900926 & Oriskany & 38.45166 & -81.65561 & 217 & 1478 & 259923 & 1199.7 \\
\hline 4705700022 & Oriskany & 39.40201 & -79.04544 & 585 & 2609 & 222 & 981.8 \\
\hline 4705900641 & Oriskany & 37.63161 & -81.87895 & 350 & 1657 & 48245 & 1026.1 \\
\hline 4706100337 & Oriskany & 39.58848 & -79.83815 & 608 & 2471 & 279860 & 1203.8 \\
\hline 4706100347 & Oriskany & 39.56573 & -79.88614 & 626 & 2446 & 271200 & 1196.2 \\
\hline 4706900038 & Oriskany & 40.05866 & -80.58205 & 396 & 2060 & 216847 & 1155.1 \\
\hline 4707100010 & Oriskany & 38.91014 & -79.34745 & 769 & 2594 & 185867 & 1122.6 \\
\hline 4707100012 & Oriskany & 38.79632 & -79.42260 & 824 & 2458 & 76479 & 1039.4 \\
\hline 4707500011 & Oriskany & 38.67495 & -79.75759 & 1052 & 1750 & 28441 & 1010.6 \\
\hline 4707500014 & Oriskany & 38.63024 & -79.78072 & 984 & 1815 & 195659 & 1140.5 \\
\hline 4707500025 & Oriskany & 38.68381 & -79.75481 & 1048 & 1771 & 282995 & 1216.2 \\
\hline 4707500034 & Oriskany & 38.66769 & -79.76184 & 1063 & 1806 & 56058 & 1030.6 \\
\hline 4707700013 & Oriskany & 39.43387 & -79.57246 & 656 & 1649 & 89348 & 1057.1 \\
\hline 4707700021 & Oriskany & 39.41043 & -79.57720 & 685 & 1630 & 122512 & 1082.9 \\
\hline 4707700058 & Oriskany & 39.40331 & -79.59137 & 536 & 1419 & 259414 & 1199.9 \\
\hline 4707700090 & Oriskany & 39.35337 & -79.60835 & 784 & 1835 & 321954 & 1242.7 \\
\hline 4707700141 & Oriskany & 39.38034 & -79.58653 & 610 & 1609 & 30887 & 1013.7 \\
\hline 4707700143 & Oriskany & 39.36482 & -79.60156 & 680 & 1651 & 313023 & 1245.9 \\
\hline 4707700155 & Oriskany & 39.38197 & -79.58294 & 610 & 1603 & 198626 & 1245.9 \\
\hline 4707700156 & Oriskany & 39.37754 & -79.59483 & 631 & 1568 & 340920 & 1272.8 \\
\hline 4707700158 & Oriskany & 39.36237 & -79.59397 & 775 & 1810 & 130370 & 1087.5 \\
\hline 4707700162 & Oriskany & 39.35409 & -79.62037 & 617 & 1611 & 324460 & 1257.3 \\
\hline 4707700164 & Oriskany & 39.33534 & -79.62316 & 794 & 1953 & 202318 & 1144.2 \\
\hline 4707700166 & Oriskany & 39.42145 & -79.54762 & 815 & 2010 & 255943 & 1189.4 \\
\hline 4707700186 & Oriskany & 39.51110 & -79.83121 & 540 & 2368 & 292200 & 1216.2 \\
\hline 4707700316 & Oriskany & 39.53456 & -79.85094 & 566 & 2358 & 255943 & 1184.4 \\
\hline
\end{tabular}




\begin{tabular}{|c|c|c|c|c|c|c|c|}
\hline Sample/API Number & Horizon & Latitude & Longitude & GL Elevation $(\mathrm{m})$ & Depth/Top (m) & TDS Calculated (mg/L) & Density $\left(\mathrm{kg} / \mathrm{m}^{3}\right)$ \\
\hline 4707900204 & Oriskany & 38.61311 & -81.74124 & 272 & 1547 & 266039 & 1204.5 \\
\hline 4708300002 & Oriskany & 38.78442 & -79.91600 & 619 & 1135 & 107840 & 1076.1 \\
\hline 4708300097 & Oriskany & 38.81316 & -79.67742 & 903 & 1608 & 97453 & 1063.8 \\
\hline 4708300118 & Oriskany & 38.78203 & -79.69855 & 987 & 1516 & 136876 & 1095.3 \\
\hline 4708300126 & Oriskany & 38.79111 & -79.69454 & 985 & 1601 & 185113 & 1134.1 \\
\hline 4708300904 & Oriskany & 38.62224 & -79.88941 & 1131 & 2503 & 191039 & 1128.0 \\
\hline 4708700239 & Oriskany & 38.61978 & -81.14033 & 314 & 1822 & 222755 & 1162.7 \\
\hline 4708700413 & Oriskany & 38.55924 & -81.39392 & 309 & 1676 & 275327 & 1210.8 \\
\hline 4708700429 & Oriskany & 38.60787 & -81.51940 & 207 & 1544 & 272738 & 1210.5 \\
\hline 4709300002 & Oriskany & 39.06310 & -79.40547 & 1019 & 2515 & 230964 & 1161.1 \\
\hline 4709702852 & Oriskany & 38.69745 & -80.28997 & 812 & 2370 & 253721 & 1182.5 \\
\hline 4709900393 & Oriskany & 38.23142 & -82.55329 & 231 & 928 & 121699 & 1088.9 \\
\hline 4710500068 & Oriskany & 38.99318 & -81.30763 & 254 & 1494 & 273600 & 1212.0 \\
\hline 4710500068 & Oriskany & 38.99318 & -81.30763 & 254 & 1494 & 274294 & 1212.6 \\
\hline 4710500171 & Oriskany & 38.91115 & -81.36267 & 246 & 1724 & 255999 & 1192.9 \\
\hline 4710500531 & Oriskany & 38.95428 & -81.29141 & 320 & 1807 & 294197 & 1226.3 \\
\hline 4710700351 & Oriskany & 39.25698 & -81.27240 & 324 & 1323 & 190000 & 1141.0 \\
\hline ED-82-37 & Oriskany & 39.97139 & -79.09139 & 646 & 2694 & 101000 & 1055.2 \\
\hline ED-82-38 & Oriskany & 39.94111 & -79.11944 & 570 & 2676 & 230000 & 1158.3 \\
\hline ED-82-39 & Oriskany & 39.93361 & -79.11056 & 642 & 2697 & 302000 & 1219.6 \\
\hline ED-82-40 & Oriskany & 40.04167 & -78.91667 & 718 & 2604 & 343000 & 1258.1 \\
\hline OHIO_12 & Oriskany & 40.85057 & -82.08988 & 357 & 652 & 252900 & 1203.1 \\
\hline OHIO_21 & Oriskany & 40.40286 & -80.71155 & 357 & 1568 & 316100 & 1249.5 \\
\hline OHIO_243 & Oriskany & 40.91527 & -81.76897 & 290 & 693 & 231090 & 1183.0 \\
\hline OHIO_287 & Oriskany & 41.32416 & -81.53710 & 347 & 753 & 197550 & 1153.3 \\
\hline OHIO_29 & Oriskany & 40.74705 & -82.40302 & 347 & 611 & 165600 & 1127.6 \\
\hline OHIO_3 & Oriskany & 40.92303 & -82.14164 & 337 & 608 & 251200 & 1202.1 \\
\hline OHIO_31 & Oriskany & 41.26723 & -81.95789 & 255 & 463 & 256100 & 1208.2 \\
\hline OHIO_32 & Oriskany & 41.15853 & -81.64475 & 318 & 650 & 246750 & 1197.5 \\
\hline
\end{tabular}




\begin{tabular}{|c|c|c|c|c|c|c|c|}
\hline Sample/API Number & Horizon & Latitude & Longitude & GL Elevation $(\mathrm{m})$ & Depth/Top (m) & TDS Calculated (mg/L) & Density $\left(\mathrm{kg} / \mathrm{m}^{3}\right)$ \\
\hline OHIO_34 & Oriskany & 41.16371 & -81.99154 & 270 & 530 & 257700 & 1209.1 \\
\hline OHIO_36 & Oriskany & 41.01102 & -82.11317 & 332 & 555 & 224800 & 1179.0 \\
\hline OHIO_57 & Oriskany & 41.40439 & -82.09609 & 191 & 337 & 168750 & 1132.4 \\
\hline OHIO_58 & Oriskany & 41.19994 & -82.01069 & 282 & 475 & 241900 & 1195.3 \\
\hline OHIO_65-88 & Oriskany & 41.90777 & -80.73238 & 190 & 494 & 284900 & 1234.1 \\
\hline OHIO_709 & Oriskany & 41.82107 & -81.00393 & 205 & 497 & 319500 & 1266.8 \\
\hline PENN_TULLY_1 & Oriskany & 42.07306 & -80.06202 & 272 & 609 & 272518 & 1221.5 \\
\hline PENN_TULLY_176 & Oriskany & 41.03091 & -78.84634 & 450 & 2213 & 327262 & 1250.3 \\
\hline PENN_TULLY_177 & Oriskany & 41.05477 & -78.75641 & 485 & 2213 & 338440 & 1260.6 \\
\hline PENN_TULLY_178 & Oriskany & 41.12063 & -78.74281 & 460 & 2189 & 324112 & 1247.4 \\
\hline PENN_TULLY_179 & Oriskany & 41.23796 & -78.62943 & 533 & 2241 & 191311 & 1131.4 \\
\hline PENN_TULLY_181 & Oriskany & 41.23262 & -78.53979 & 478 & 2188 & 232255 & 1166.2 \\
\hline PENN_TULLY_183 & Oriskany & 40.84483 & -78.44819 & 526 & 2440 & 253770 & 1181.2 \\
\hline PENN_TULLY_183a & Oriskany & 40.84483 & -78.44819 & 526 & 2449 & 330389 & 1249.0 \\
\hline PENN_TULLY_185 & Oriskany & 41.06146 & -78.81391 & 472 & 2270 & 328338 & 1250.5 \\
\hline PENN_TULLY_185a & Oriskany & 41.06146 & -78.81391 & 472 & 2211 & 336042 & 1258.4 \\
\hline PENN_TULLY_186 & Oriskany & 41.21724 & -78.53979 & 352 & 2089 & 240329 & 1174.5 \\
\hline PENN_TULLY_187 & Oriskany & 41.07349 & -78.73435 & 512 & 2257 & 274977 & 1202.5 \\
\hline PENN_TULLY_189 & Oriskany & 41.07884 & -78.72566 & 487 & 2207 & 190401 & 1131.2 \\
\hline PENN_TULLY_190 & Oriskany & 41.08218 & -78.71630 & 471 & 2205 & 325408 & 1248.6 \\
\hline PENN_TULLY_191 & Oriskany & 41.04140 & -78.77714 & 443 & 2198 & 325054 & 1248.3 \\
\hline PENN_TULLY_192 & Oriskany & 41.05343 & -78.81325 & 450 & 2212 & 316299 & 1240.2 \\
\hline PENN_TULLY_193 & Oriskany & 39.82755 & -78.35384 & 331 & 1402 & 159797 & 1115.4 \\
\hline PENN_TULLY_193a & Oriskany & 39.82755 & -78.35384 & 331 & 1437 & 297592 & 1234.5 \\
\hline PENN_TULLY_194 & Oriskany & 40.79758 & -78.99555 & 423 & 2199 & 319848 & 1243.5 \\
\hline PENN_TULLY_195 & Oriskany & 41.38039 & -78.33475 & 516 & 2089 & 268721 & 1199.1 \\
\hline PENN_TULLY_196 & Oriskany & 40.85196 & -79.01606 & 479 & 2323 & 297265 & 1221.5 \\
\hline PENN_TULLY_197 & Oriskany & 41.40103 & -78.28866 & 423 & 2014 & 325009 & 1251.5 \\
\hline
\end{tabular}




\begin{tabular}{|c|c|c|c|c|c|c|c|}
\hline Sample/API Number & Horizon & Latitude & Longitude & GL Elevation (m) & Depth/Top (m) & TDS Calculated (mg/L) & Density $\left(\mathrm{kg} / \mathrm{m}^{3}\right)$ \\
\hline PENN_TULLY_198 & Oriskany & 39.76393 & -78.38837 & 333 & 1515 & 139277 & 1097.2 \\
\hline PENN_TULLY_199 & Oriskany & 40.87603 & -78.89214 & 612 & 2306 & 279698 & 1205.9 \\
\hline PENN_TULLY_200 & Oriskany & 40.62273 & -79.41129 & 324 & 2349 & 303654 & 1226.4 \\
\hline PENN_TULLY_203 & Oriskany & 41.16105 & -78.67281 & 501 & 2259 & 274542 & 1202.1 \\
\hline PENN_TULLY_204 & Oriskany & 41.06213 & -78.73168 & 449 & 2187 & 330058 & 1252.9 \\
\hline PENN_TULLY_205 & Oriskany & 41.03781 & -78.78422 & 429 & 2214 & 250203 & 1181.6 \\
\hline PENN_TULLY_209 & Oriskany & 40.10795 & -79.06582 & 629 & 2566 & 127477 & 1077.0 \\
\hline PENN_TULLY_210 & Oriskany & 40.09538 & -79.29357 & 666 & 2236 & 315328 & 1238.6 \\
\hline PENN_TULLY_211 & Oriskany & 40.09686 & -79.07691 & 647 & 2594 & 154357 & 1097.5 \\
\hline PENN_TULLY_212 & Oriskany & 40.10647 & -79.28839 & 747 & 2383 & 308131 & 1230.4 \\
\hline PENN_TULLY_213 & Oriskany & 40.11756 & -79.05325 & 637 & 2341 & 172401 & 1114.7 \\
\hline PENN_TULLY_214 & Oriskany & 40.12865 & -79.04215 & 621 & 2615 & 250199 & 1176.0 \\
\hline PENN_TULLY_215 & Oriskany & 40.06506 & -79.09540 & 628 & 2579 & 281474 & 1203.7 \\
\hline PENN_TULLY_216 & Oriskany & 40.09168 & -79.11018 & 621 & 2601 & 220885 & 1151.4 \\
\hline PENN_TULLY_217 & Oriskany & 40.16341 & -79.14050 & 753 & 2477 & 414614 & 1328.6 \\
\hline PENN_TULLY_217a & Oriskany & 40.16341 & -79.14050 & 753 & 2455 & 124060 & 1075.5 \\
\hline PENN_TULLY_220a & Oriskany & 40.00221 & -79.33054 & 843 & 2470 & 122695 & 1074.4 \\
\hline PENN_TULLY_224 & Oriskany & 41.35134 & -80.19413 & 404 & 1219 & 330382 & 1268.1 \\
\hline PENN_TULLY_225 & Oriskany & 40.32857 & -79.26270 & 824 & 2298 & 277677 & 1204.1 \\
\hline PENN_TULLY_227 & Oriskany & 40.22254 & -79.38544 & 640 & 2539 & 317284 & 1235.5 \\
\hline PENN_TULLY_227a & Oriskany & 40.22254 & -79.38544 & 640 & 2539 & 321308 & 1239.1 \\
\hline PENN_TULLY_229 & Oriskany & 40.38876 & -78.82247 & 650 & 2697 & 312823 & 1229.2 \\
\hline PENN_TULLY_3 & Oriskany & 41.91240 & -77.17413 & 482 & 1315 & 276234 & 1216.4 \\
\hline PENN_TULLY_4 & Oriskany & 41.67769 & -79.39847 & 500 & 1321 & 309560 & 1247.0 \\
\hline PENN_TULLY_45 & Oriskany & 40.17965 & -79.43499 & 540 & 2236 & 272298 & 1200.1 \\
\hline PENN_TULLY_5 & Oriskany & 41.45388 & -80.36174 & 302 & 977 & 332297 & 1273.4 \\
\hline PENN_TULLY_52 & Oriskany & 41.36045 & -77.91030 & 309 & 1841 & 345000 & 1272.7 \\
\hline PENN_TULLY_56 & Oriskany & 41.91516 & -77.16770 & 482 & 1315 & 278048 & 1218.0 \\
\hline
\end{tabular}




\begin{tabular}{|c|c|c|c|c|c|c|c|}
\hline Sample/API Number & Horizon & Latitude & Longitude & GL Elevation (m) & Depth/Top (m) & TDS Calculated (mg/L) & Density $\left(\mathrm{kg} / \mathrm{m}^{3}\right)$ \\
\hline PENN_TULLY_59 & Oriskany & 40.41272 & -80.31738 & 320 & 1908 & 264835 & 1198.6 \\
\hline PENN_TULLY_68 & Oriskany & 41.06012 & -78.72298 & 456 & 2215 & 248511 & 1180.1 \\
\hline PENN_TULLY_69 & Oriskany & 41.14331 & -78.61464 & 502 & 2296 & 274763 & 1201.5 \\
\hline PENN_TULLY_78 & Oriskany & 40.20258 & -79.40985 & 573 & 2258 & 302000 & 1226.5 \\
\hline PENN_WEST_1101 & Oriskany & 41.17930 & -78.60232 & 495 & 2246 & 312000 & 1235.5 \\
\hline PENN_WEST_1102 & Oriskany & 41.07578 & -78.71878 & 456 & 2215 & 279000 & 1206.7 \\
\hline PENN_WEST_1103 & Oriskany & 41.16474 & -78.61849 & 502 & 2295 & 311000 & 1233.8 \\
\hline PENN_WEST_1203 & Oriskany & 42.07863 & -80.08718 & 272 & 609 & 256000 & 1206.4 \\
\hline 4703905269 & Oriskany & 38.44251 & -81.40303 & 368 & 1706 & 129349 & 1087.7 \\
\hline 4703901533 & Oriskany & 38.44865 & -81.43750 & 307 & 1654 & 92283 & 1059.4 \\
\hline 4707500026 & Oriskany & 38.66391 & -79.76351 & 1072 & 1794 & 21691 & 1005.2 \\
\hline 4707500033 & Oriskany & 38.65999 & -79.76554 & 1014 & 1740 & 37090 & 1017.0 \\
\hline 4708300124 & Oriskany & 38.74918 & -79.72155 & 1061 & 1624 & 1836 & 992.0 \\
\hline 4708300096 & Oriskany & 38.75422 & -79.72298 & 990 & 1572 & 3622 & 993.7 \\
\hline 4703901352 & Oriskany & 38.52411 & -81.48586 & 260 & 1581 & 51230 & 1028.8 \\
\hline 4703500486 & Oriskany & 38.88430 & -81.68152 & 201 & 1481 & 55722 & 1033.0 \\
\hline 4703500911 & Oriskany & 38.88024 & -81.69545 & 223 & 1498 & 99380 & 1066.3 \\
\hline 4703500531 & Oriskany & 38.85337 & -81.69466 & 225 & 1504 & 148323 & 1105.0 \\
\hline 4703500512 & Oriskany & 38.83755 & -81.67890 & 208 & 1502 & 217147 & 1162.2 \\
\hline 4703502408 & Oriskany & 38.82390 & -81.68112 & 225 & 1512 & 202822 & 1150.1 \\
\hline 4703502464 & Oriskany & 38.84409 & -81.69855 & 184 & 1462 & 82199 & 1053.0 \\
\hline 4710700336 & Oriskany & 39.07782 & -81.53571 & 300 & 1598 & 226438 & 1169.1 \\
\hline 4710700306 & Oriskany & 39.05808 & -81.55022 & 329 & 1640 & 222516 & 1165.1 \\
\hline 3407321971 & Oriskany & 39.51075 & -82.55570 & 340 & 665 & 194292 & 1151.4 \\
\hline
\end{tabular}

